\title{
Cost Analysis for Application of Solidified Waste Fission Product Canisters in U.S. Army Steam Plants
}

300A00934

by

W. E. Sande

W. J. Bjorklund

N. A. Brooks

\section{April 1977}

Prepared for the Energy Research and Development Administration under Contract EY-76-C-06-1830 


\title{
NOTICE
}

This report was prepared as an account of work sponsored by the United States Government. Neither the United States nor the Energy Research and Development Administration, nor any of their employees, nor any of their contractors, subcontractors, or their employees, makes any warranty, express or implied, or assumes any legal liability or responsibility for the accuracy, completeness or usefulness of any information, apparatus, product or process disclosed, or represents that its use would not infringe privately owned rights.

The views, opinions and conciusions contained in this report are those of the contractor and do not necessarily represent those of the United States Government or the United States Energy Research and Development Administration.

\author{
PACIFIC NORTHWEST LABORATORY \\ operated by \\ BATTELLE \\ for the \\ ENERGY RESEARCH AND DEVELOPMENT ADMINISTRATION \\ Under Contract EY-76-C-06-1830
}

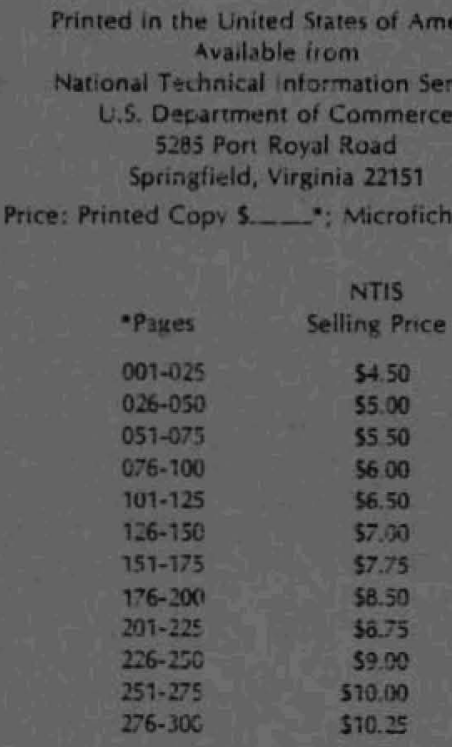


COST ANALYSIS FOR APPLICATION

OF SOLIDIFIED WASTE FISSION

PRODUCT CANISTERS

IN U.S. ARMY STEAM PLANTS

$300 A 00934$

W. E. Sande

W. J. Bjorklund

N. A. Brooks

April 1977

BATTELLE

Pacific Northwest Laboratories

Richland, Washington 99352 


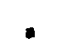

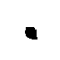

.

$\therefore$ 


\section{SUMMARY}

Battelle, Pacific Northwest Laboratory (PNL) is studying the use of fission products in thermal energy systems. This ongoing program is under joint sponsorship of the U.S. Army and the Energy Research and Development Administration, Division of Nuclear Research and Applications (ERDA-NRA). The program objective is to develop the best application of these heat generating radioisotopes for potential Army use.

To date, program emphasis has been on the economic feasibility of fueling 5-, 10-, and 20-MW steam plants with solidified waste fission products contained in stainless steel canisters [typically from 30.5 to $61.0 \mathrm{~cm}$ (12 to $24 \mathrm{in.}$ ) in diameter and 305 to $460 \mathrm{~cm}$ ( 10 to $15 \mathrm{ft}$ ) long]. Since various private industry and government groups would be affected by the Army's use of these canisters, the philosophies of these groups have been projected by PNL; all philosophies are economic and safety/licensing related. The characteristics and availability of the canisters have been projected. Six waste forms have been considered: borosilicate glass, borosilicate glass with internal fins, calcine-aluminum metal matrix, borosilicatealuminum metal matrix, pure calcine, and pure calcine with internal fins. The form that will most likely be used for the initiai solidified waste is borosilicate giass with fins due to its relatively high thermal conductivity, low solubility, and satisfactory waste density. A form showing some improvement in waste density and heat loading is calcine-aluminum metal matrix, but it requires further development. The first solidified waste could be available in 1981 to 1984, but pilot-plant studies of waste disposal methods may essentially eliminate any canisters for fueling Army steam plants until the 1990 's.

Restrictions will be piaced on canister parameters by the permanent disposal method and, if used, by the Retrievable Surface Storage Facility (RSSF). Preliminary criteria for salt mine disposal are canisters $305 \mathrm{~cm}$ long, $40.6 \mathrm{~cm}$ dia, wall temperature of $250^{\circ} \mathrm{C}$, and heat loading of $5 \mathrm{~kW}$. The RSSF criteria are canisters $457 \mathrm{~cm}$ long, $61 \mathrm{~cm}$ dia, wall temperature 
of $427^{\circ} \mathrm{C}$, and heat loading of $13 \mathrm{~kW}$. These criteria are not firm and have some leeway, but show the order of magnitude.

Various strategies for Army canister use, based on borosilicate glass, calcine-aluminum matrix, and calcine forms, have been considered. One that shows potential is 2-year-old borosilicate glass (with fins) in $40.6 \mathrm{~cm}$ dia $305 \mathrm{~cm}$ long canisters. Initial heat loading would be $25.3 \mathrm{~kW} / \mathrm{can}$. The canisters could be stored 8 years (final heat loading of $5.0 \mathrm{~kW} / \mathrm{can}$.) with a resupply rate of 90 canisters/year. The total number of canisters (ranging in waste age from 2 to 10 years) required for a 5-MW steam plant $(80 \%$ efficient) would be 720 . After use, these canisters would meet the preliminary salt mine storage criteria. Another scheme would be to use 2-year-old waste in the calcine-aluminum matrix with $40.6 \mathrm{~cm}$ dia $-305 \mathrm{~cm}$ long canisters. Initial heat load would be $44.5 \mathrm{~kW} / \mathrm{can}$. and after 27 years the heat load is $5.0 \mathrm{~kW} / \mathrm{can}$. Resupply would be 27 canisters/year and a 5-MW plant would require 702 canisters (waste age 2 to 29 years). After 27 years storage, the preliminary salt mine criteria are met.

The licensing and safety of an Army steam plant has been considered and indications are that steam plant design should closely follow past work on the Retrievable Surface Storage Facility (RSSF) ${ }^{(1)}$ and spent fuel storage facilities; for example, stainless steel water basin liners and the double barrier concept (between the waste and environment) should be maintained. Licensing procedures are expected to follow those recommended for an independent spent fuel storage facility $(2)$ since the amount of contained radioactivity and heat generation are similar.

For steam plant design, two boiler concepts were considered in detail. Concept 1 is based on earlier work on this application of waste fission products. (3) The boiler has a large outer shell surrounding open-ended boiler tubes. The canisters are inserted into the boiler tubes while the working fluid is contained between the tubes and the shell. A water-filled tank provides radiation shielding. Concept 2 is based on a large water basin boiler covered with a removable pressure head. The working fluid is in direct contact with the canisters and passes through a secondary heat exchanger to produce usable steam. Shielding is provided by the working fluid. 
Based on studies of canister temperature distributions and boiler heat transfer, steam plants were sized for six and eight various waste formcanister diameter combinations for Concept 1 and Concept 2, respectively. For both concepts the Canister Receiving Facility provides a water basin for canister removal from the transport cask. Cranes are provided for canister handling, cooling towers are used for secondary cooling, and the water basins (Concept 1) or boiler cells (Concept 2) are lined with stainless steel. Many of the capabilities and associated design provided with both Concepts 1 and 2 are based on past work on the RSSF. $(4,5)$

Important to the economic feasibility of this type of steam plant is the cost of transporting these canisters from the nuclear fuel reprocessing plant (where they are made) to the Army steam plant, and after use, the transport costs from the steam plant to a disposal site. These costs are estimated and included in an overall economic study of these plants.

The capital and operating costs are developed for Concepts 1 and 2. Concept 2 appears to have an economic advantage due to a reduction in the amount of stainless steel used; even with carbon steel boilers and other equipment, Concept 1 is more costly.

An overall economic analysis includes transport costs, steam plarit capital and operating costs, fuel oil boiler capital and operating savings, and fuel reprocessor savings. In the latter case it is assumed a fuel reprocessor would be willing to pay the Army an amount equal to what it would cost the fuel reprocessor to store the canisters and transport them from the fuel reprocessing plant to the disposal site.

The results for several cases of concept 2 are summarized below. The units are in equivalent fuel oil price, $\$ /$ gal, i.e., the price of fuel oil that would allow steam plants fueled with waste fission product canisters to compete economically with fuel oil systems. 


\begin{tabular}{|c|c|c|c|c|}
\hline \multirow{2}{*}{$\begin{array}{l}\text { Canister } \\
\text { Diameter, } \\
\mathrm{cm} \text { (in.) }\end{array}$} & \multirow[b]{2}{*}{ Waste Form } & \multicolumn{3}{|c|}{$\begin{array}{c}\text { Equivalent Fuel 0il Price, } \\
\$ / \text { gal }(1976 \$)\end{array}$} \\
\hline & & $5 \mathrm{MW}$ & $10 \mathrm{MW}$ & $20 \mathrm{MW}$ \\
\hline $30.5(12)$ & $\begin{array}{l}\text { Borosilicate } \\
\text { Glass }\end{array}$ & 1.20 & 0.80 & 0.58 \\
\hline $40.6(16)$ & $\begin{array}{l}\text { Borosilicate } \\
\quad \text { Glass }\end{array}$ & 1.37 & 0.98 & 0.76 \\
\hline $40.6(16)$ & $\begin{array}{c}\text { Calcine-Al } \\
\text { Matrix }\end{array}$ & 1.22 & 0.83 & 0.61 \\
\hline $25.4(10)$ & Calcine ${ }^{(a)}$ & 1.64 & 1.24 & 1.02 \\
\hline
\end{tabular}

(a) Internal Fins

For the above costs to be approached, the following factors are important:

- The fuel reprocessor must be willing to pay a significant portion of the storage and transport costs.

- The Army steam plant should be within 200 miles or less of the fuel reprocessing plant and be about $20 \mathrm{MW}$ in size.

- The Army should own the transport casks.

- The capital cost for a 20-MW steam plant should be about $\$ 40 \times 10^{6}$ or less.

The economic feasibility of these steam plants is borderline at this time. The most optimistic case is a competitive fuel oil price of about $\$ 0.60 /$ gal which is presently above current fuel oil prices (about \$0.45/gal). However, a fuel oil price increase to above $\$ 1.00 /$ gal could make these plants economical in the future. It is likely that it would take eight to ten years to bring a steam plant of this type on-line. For that reason, it probably could not be built in time to assist the Allied-General Nuclear Services plant at Barnwell, South Carolina, but it could possibly be built to assist in storing the canisters from a plant proposed to be built near Oak Ridge, Tennessee by Exxon Nuclear Co., Inc. (6) This plant would begin operation in 1984 at the earliest and would begin waste solidification probably in 1986 or 1987. A plant of this size, 1500 Metric Tonne Heavy Metal/yr, could probably supply one or two 20-MW plants. 
These steam plants may have merit for implementation in the future. Due to the uncertainties in design and the economic analysis, the following steps should be completed before full scale design is started on a steam plant:

1. Discussions should be held with the fuel reprocessors to determine the amount they would be willing to pay the Army.

2. The Nuclear Regulatory Commission should be consulted on steam plant licensing.

3. The economics should be revised based on steps 1 and 2 above.

4. A research and development plan should be developed if the economics warrant further work.

5. Periodic reviews should be made of nuclear waste management, nuclear regulations, steam plant costs, etc., to be certain the plants are still uneconomical or economical, as the case may be.

Unfortunateiy, the bases for the projections of waste quantities, waste age, canister availability, and canister parameters have changed since January 1977; most of this study was completed before that time. In particular, the future of fuel reprocessing is uncertain due to the Carter Administration's policy on nuclear power. It is like?y that the present situation will at least delay canister availability from that stated in the preceding paragraphs and 2-yr-old solidified waste may be optimistic. The result will be an increase in steam plant costs. Due to these uncertainties, it is recommended that the concept of fueling an Army steam plant with solidified waste fission product canisters be not considered further until a firm decision to reprocess spent nuclear fuel is made.

Since the amount of spent fuel stored and length of storage time will probably increase due to the present situation in the nuclear fuel cycle, an economic feasibility analysis of fueling Army steam plants with spent fuel elements may be warranted. The concepts and costs presented in this analysis reported here could be used as a basis. 
CONTENTS

LIST OF FIGURES . . . . . . . . . . . . . . . . . . . $\mathrm{x}$ LIST OF TABLES . . . . . . . . . . . . . . . . . . . . $x^{\circ}$ 1.0 INTRODUCTION . . . . . . . . . . . . . . . . . . . 1-1

2.0 PHILOSOPHIES - FUEL REPROCESSOR, U.S. ARMY, ERDA, NRC, NRA . . . 2-1 2.1 FUEL REPRDCESSOR . . . . . . . . . . . . . . . 2-1

2.2 U.S. ARMY . . . . . . . . . . . . . . . . 2-3

2.3 ENERGY RESEARCH AND DEVELOPMENT ADMINISTRATION (ERDA) . . . 2-3

2.4 NUCLEAR REGULATORY COMMISSION (NRC) . . . . . . . . . 2-4

2.5 NUCLEAR RESEARCH AND APPLICATIONS (NRA) . . . . . . . 2-4

3.0 FORECAST OF SOLIDIFIED WASTE SUPPLY . . . . . . . . . . . . 3-1

4.0 PRESENT WASTE SOLIDIFICATION STRATEGY . . . . . . . . . . . . .

4.1 SOLIDIFICATION PROCESSES . . . . . . . . . . . . 4-1

Nuclear Fuel Services . . . . . . . . . . . . . 4-1

Allied-General Nuclear Services . . . . . . . . . 4-1

The "French Process" . . . . . . . . . . . . . 4-3

4.2 WASTE CANISTER CHARACTERISTICS . . . . . . . . . . 4-3

Spray Calcination/In-Can Melting Process . . . . . . . 4-3

5.0 ALTERNATE SOLIDIFICATION STRATEGIES AND PROCESSES . . . . . . .

6.0 STRATEGIES FOR ARMY CANISTER USE . . . . . . . . . . . . 6-1

7.0 STEAM PLANT LICENSING AND SAFETY . . . . . . . . . . . . .

7.1 STEAM PLANT DESCRIPTION . . . . . . . . . . . . . . .

7.2 CODE OF FEDERAL REGULATIONS . . . . . . . . . . . . . . 7-2

7.3 RETRIEVABLE SURFACE STORAGE FACILITY (RSSF) . . . . . . . 7-2

7.4 SPENT FUEL STORAGE FACILITIES . . . . . . . . . . . . 7-3

7.5 ARMY STEAM PLANT . . . . . . . . . . . . . . 7-5

8.0 STEAM PLANT DESIGN . . . . . . . . . . . . . . . . . 8 .

8.1 BOILER CONCEPTS . . . . . . . . . . . . . . . . . .

8.2 BOILER HEAT TRANSFER . . . . . . . . . . . . . . 8-5

8.3 CANISTER TEMPERATURE DISTRIBUTIONS • . . . . . . . . .

8.4 STEAM PLANT SIZE . . . . . . . . . . . . . . . . . 8-13

8.5 STEAM PLANT OPERATION . . . . . . . . . . . . . .

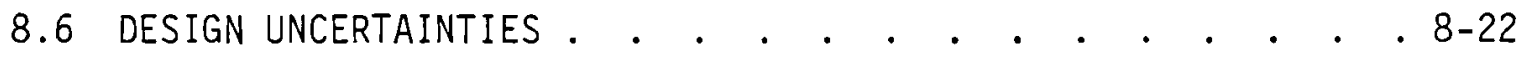


CONTENTS (contd)

9.0 TRANSPORTATION . . . . . . . . . . . . . . . . . . . . 9-1

9. 1 REGULATIONS-TRANSPORTATION OF RADIOACTIVE MATERIALS . . . . 9-1

Federal Regulations . . . . . . . . . . . . . 9-1

State and Local Regulations. . . . . . . . . . . 9-3

Railroad Transport Constraints . . . . . . . . . 9-4

9.2 ARMY TRANSPORT DESCRIPTION . . . . . . . . . . . . $9-5$

9.3 TRANSPORTATION COSTS . . . . . . . . . . . . . 9-10

10.0 ECONOMICS OF ARMY STEAM PLANTS . . . . . . . . . . . . . . 10-1

10.1 STEAM PLANT CAPITAL COSTS . . . . . . . . . . . . . . . .

10.2 OPERATING COSTS . . . . . . . . . . . . . . . . . . . . . . .

10.3 FUEL OIL BOILER CAPITAL AND OPERATING COSTS . . . . . . 10-8

10.4 FUEL REPROCESSOR SAVINGS - ARMY CREDIT FOR

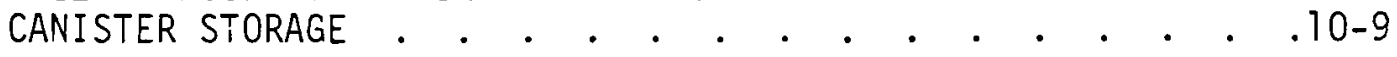

10.5 OVERALL ECONOMICS . . . . . . . . . . . . . . . . $10-13$

11.0 DEVELOPMENT PLANS . . . . . . . . . . . . . . . . . . . . . . . . .

12.0 UPDATE AND RECOMMENDATIONS . . . . . . . . . . . . . . . . . . . . .

13.0 ACKNOWLEDGMENTS. . . . . . . . . . . . . . . . . . . . . . . . .

$\begin{aligned} \text { APPENDIX A - } & \text { BASES FOR PROJECTIONS OF CAPACITY, MATERIALS FLOWS, } \\ & \text { AND WASTE GENERATION INVOLVING LIGHT WATER REACTORS . . . A-1 }\end{aligned}$

APPENDIX B - DETAILS OF CANISTER TEMPERATURE DISTRIBUTION . . . . . B-1

APPENDIX C - DETAILS OF CAPITAL INVESTMENT . . . . . . . . . . . . C-

APPENDIX D - SPECIAL EQUIPMENT DESIGN AND COST . . . . . . . . . . D-

APPENDIX E - REFERENCES . . . . . . . . . . . . . . . . . E-T 


\section{LIST OF FIGURES}

2.1 The LWR fuel Cycle. . . . . . . . . . . . . 2-2

4.1 Spray Calciner/In-Can Melter Process . . . . . . . . 4-2

4.2 Typical In-Can Me1ter Canister. . . . . . . . . . 4-4

4.3 Thermal Output of Canister . . . . . . . . . . . 4-4

4.4 Allowable Canister Diameter . . . . . . . . . . . . 4-5

5.1 Therma 1 Decay of HLLW, Strontium, and Cesium . . . . . 5-2

5.2 Heat Loading of 2 -yr-old Waste When Stored at
Canister Wall Temperature of $200^{\circ} \mathrm{C}$. . . . . . . . . . 5-4

5.3 Comparison of Canister Diameter and Waste Form . . . . . 5-6

6.1 Canister Heat Generation Rate with Decay . . . . . . . 6-4

8.119 Canister Array . . . . . . . . . . . . . . . 8-2

8.237 Canister Array . . . . . . . . . . . . . . . 8-2

8.3. Schematic of Concept 1 . . . . . . . . . . . . . 8-4

8.4 Schematic of Concept 2 . . . . . . . . . . . . . 8-4

8.5 Boiler Layout . . . . . . . . . . . . . . . 8-14

8.6 Boiler Facility. . . . . . . . . . . . . . . 8-15

8.7 Boiler with Water Tank for Shielding . . . . . . . . 8-16

8.8 Water Basin for Canister Handling . . . . . . . . . . 8-17

8.9 Receiver Facility . . . . . . . . . . . . . 8-18

9.1 High-Level Solid Radioactive Waste Shipping Cask. . . . . 9-7

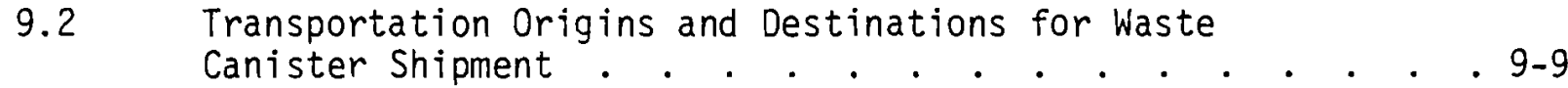

9.3 Price Indexes for Total Railroad Freight and
Wholesale Price Index, A11 Commodities 


\section{$\underline{\text { LIST OF TABLES }}$}

3.1 Forecast of Solidified Waste Supply . . . . . . . . 3-2

5.1 Waste Heat Generation Rates . . . . . . . . . 5-3

5.2 Product Properties . . . . . . . . . . . . . 5-4

6.1 Prediction of Waste Canister Availability. . . . . . . 6-2

6.2 Army Steam Plants - 5-MW . . . . . . . . . . . 6-5

8.1 Physical Properties and Critical Heat Flux

8.2 Boiler Heat Transfer . . . . . . . . . . . . 8-7

8.3 Canister Temperatures . . . . . . . . . . . . 8-12

8.4 5-MW Steam Plant - Boiler and Plant Dimensions . . . . . 8-14

9.1 Summary of Assumptions Used in Cost Analysis . . . . . . 9-8

9.2 Summary of Estimated Freight Charges, Train-Miles,

Special-Train Charges, and Transit Times. . . . . 9-11

9.3 Estimated Round Trip Transit Times and Distances of Representative Transportation Routes . . . . . . 9-15

9.4 Summary of Resupply Transportation Costs -

Concepts 1.2 and 2.2 (5-MW Plant) . . . . . . . . 9-16

9.5 Annual Resupply Transportation Costs - A11 Concepts. . . . 9-18

9.6 Initiâl Loading Costs - Concepts 1.2 and 2.2 . . . . . . 9-20

9.7 Initial Loading Transportation Costs - A11 Concepts,
Equivalent Fuel Oil Price, \$/gal. . . 9-21

10.1 Capital Costs of the Water Basin Receiving Facility . . 10-2

10.2 Capital Costs of the Hot Cell Receiving Facility . . . 10-2

10.3 Capital Cost for Sitework, Yardwork, Exhaust Fan and

Filter House, and Communications and Alarm - 5 MW Plant . 10-3

10.4 Sunmary of Capital Costs, $\$ \times 10^{6}$. . . . . . . . . 10-5

10.5 Capital Costs for Concepts Using Canisters 16 in. Diameter, Borosilicate Glass with Fins, 5-MW Plants, $\$ \times 10^{3}$. . . . . . . . . . $10-6$

10.6 Labor Costs, 5-MW Plant, $\$ \times 10^{3}$. . . . . . . . . 10-7

10.7 Utilities and Total Operating Costs for Army Steam

Plants... . . . . . . . . . . . 10-8

10.8 Fuel 0i1 Boiler Capital and Operating Costs, $\$ \times 10^{3}$. . . 10-9

10.9 Fuel Reprocessing Plant's Storage Facility Cost Savings . . 10-10 


\section{LIST OF TABLES (contd)}

10.10 Number of Army Steam Plants Required to Eliminate Fue1 Reprocessor Canister Storage . . . . . . . . . . 10-11

10.11 Annual Cost of Canister Storage to the Fuel Reprocessor Potential Credit to the Army, $\$ \times 10^{3}$. . . . . . . . 10-13

10.12 Overall Steam Plant Cost in Equivalent Fuel 0il Price . . . 10-16 A.1 Projected Nuclear LWR Operating Capacity . . . . . . . A-4

A.2 Predicted Distribution of LWR Spent Fuel Reprocessing Among U.S. Facilities in the Near Term . . . . . . . . A-5

\section{A.3 Comparison of Reprocessing Requirements and} Activities . . . . . . . . . . . . . . . . . A-6

\section{A.4 Projected Accumulation of Solidified Wastes at} Fuel Reprocessing Plants Before Shipment. . . . . . . A-7

A.5 Containers of 10-yr-old LWR High-Level Waste Shipped . . . A-8

A.6 Projected Accumulation of Solidified LWR High-Leve 1 Wastes at a Federal Repository. . . . . . . . . . . A-9

B.1 Canister Temperature Distribution Computer Results . . . . B-2

C.1 Water Basin Receiving Facility. . . . . . . . . . . C-2

C.2 Hot Cell Receiving Facility. . . . . . . . . . . . C-5

C.3 Boiler Facility (Concepts 1.2 and 1.4) . . . . . . . . C-9

C.4 Special Equipment (Concepts 1.2 and 1.4) . . . . . . . C-10

C.5 Boiler Facility (Concept 2.2) . . . . . . . . . . . C-11

C.6 Special Equipment (Concept 2.2) . . . . . . . . . . C-12

C.7 Sitework, Yardwork, Exhaust Fan and Filter House,

D.1 Removable Pressure Head Costs . . . . . . . . . . . D-2 
1.0 INTRODUCTION 
'

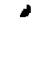

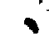




\subsection{INTRODUCTION}

Battelle, Pacific Northwest Laboratory (PNL) was commissioned by the U.S. Army and the Energy Research and Development Administration, Division of Nuclear Research and Applications (ERDA-NRA) in a joint program to study the use of radioisotopes in thermal energy systems. The program, entitled Application of Waste Fission Products in Thermal Energy Systems on U.S. Army Installations, was initiated in early March, 1976. The main emphasis of this present investigation is the use of solidified waste fission product canisters in Army steam plants with capacities between 5 - and $20-\mathrm{MW}$ of $350^{\circ} \mathrm{F}$ $\left(176^{\circ} \mathrm{C}\right)$ saturated steam. The overall objective and benefit is to reduce costs by replacing fuel oil with heat-generating waste fission products which are a by-product of the nuclear fuel cycle.

The main objectives of the present study are to design steam plants using projected waste fission product canister characteristics, to analyze the overall impact and cost/benefit to the nuclear fuel cycle associated with these plants, and to develop plans for this application if the cost analys is so warrants it.

The construction and operation of a steam plant fueled with waste fission product canisters would require the involvement and cooperation of various government agencies and private industry; thus the philosophies of these groups were studied. These philosophies are discussed in the next section which is fol lowed by a forecast of canister supply, canister characteristics, and strategies for Army canister use. Another section describes the safety and licensing of these steam plants since this affects design and capital costs. The discussion of steam plant design includes boiler concepts, boiler heat transfer, canister temperature distributions, steam plant size, and steam plant operation. Also, canister transportation is discussed since this influences operating costs. Details of economics of Army steam plants are provided including steam plant capital costs, operating costs, fuel reprocessor savings due to Army canister storage, and overall economics. Recommendations are made in the final section. 
$\bullet$

.

$s$ 
2.0 PHILOSOPHIES - FUEL REPROCESSOR, U.S. ARMY, ERDA, NRC, NRA 


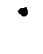

-

. 


\subsection{PHILOSOPHIES - FUEL REPROCESSOR, U.S. ARMY, ERDA, NRC, NRA}

A major program objective is to consider the impact of the Army's use of waste fission product canisters on the overall nuclear fuel cycle with emphasis on overall cost/benefit relationships. As a basis, a description is presented below of our assessment of the philosophies of who would be affected by this application of waste fission products.

The Army canister would have the greatest influence on the fuel reprocessing and waste storage phases of the nuclear fuel cycle (Figure 2.1). During reprocessing of the spent fuel, the uranium and plutonium are separated by solvent extraction (from waste fission products and other actinides) and are recycled into the fuel cycle. The portion not recycled is termed High Level Liquid Waste (HLLW). Other waste is also generated from various plant operations, but due to its lower radioactivity, it is termed Intermediate Level Liquid Waste (ILLW). These heat-generating wastes will be stored in underground stainless steel storage tanks and then converted to solid calcine, glass, or other forms, placed in metal canisters, and shipped to a federal repository. The final decisions concerning the permanent disposal in a federal repository will be based on pilot-plant studies of final disposal methods. Another possibility for waste siorage is the use of interim storage such as the Retrievable Surface Storage Facility (RSSF) or U.S. Army thermal energy systems before permanent disposal.

\subsection{FUEL REPROCESSOR}

The fuel reprocessor is interested in the most economical means of waste disposal. This inherently would be the most reliable, safest, publicly accepted method. It may not be the ultimate method but it must be an accepted method meeting al1 government regulations. Current regulations (see Part 50, Appendix $F$ of Ref. 7) state that the fuel reprocessor can store the HLLW in 1 iquid form for $5 \mathrm{yr}$ after separation and as a solid $10 \mathrm{yr}$ after separation. 


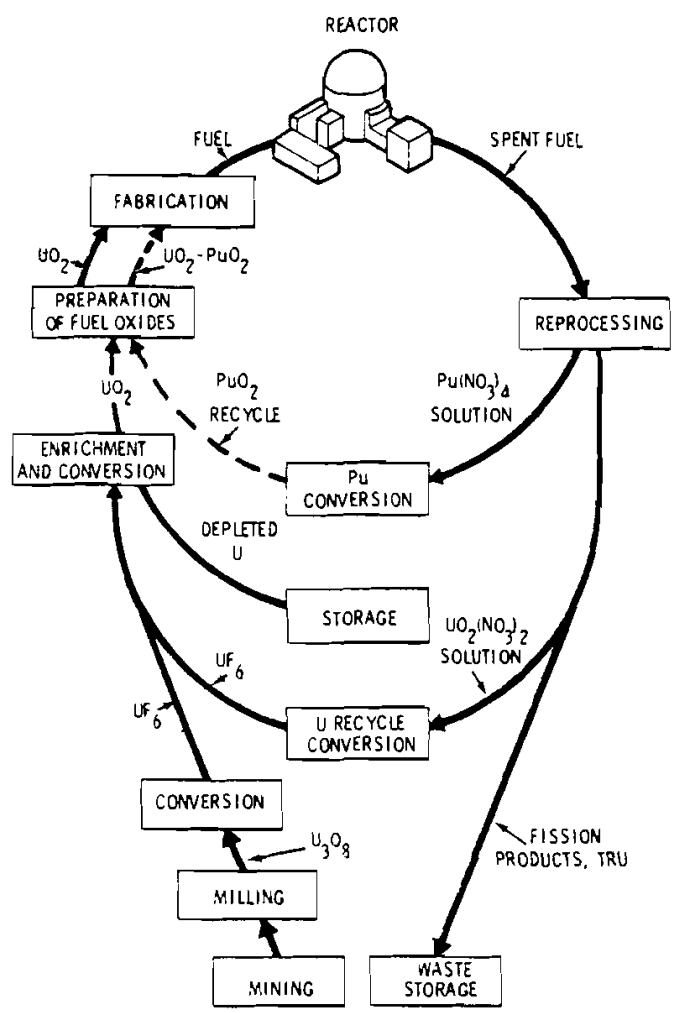

FIGURE 2.1. The LWR Fuel Cycle

Liquid storage of radioactive waste is very expensive. Storage tanks at A1lied-General Nuclear Services (AGNS) plant at Barnwe11, South Carolina are 300,000 gal capacity with about a 1.3 yr storage volume each $(11)$ and cost $\sim \$ 6 \times 10^{6}$ each. Three tanks have been constructed and several others may be built. Since tanks constructed at future sites would be of comparable cost, it would be advantageous to rapidly solidify the waste to decrease storage tank capital investment. Absolute costs are not available for the waste solidification portion of the fuel cycle since current regulations are not specific and many factors are involved such as:

- type of product - glass, calcine, other

- early solidification - higher heat generation and smaller canisters

- late solidification - low heat generation in larger canisters

- transportation costs

- storage costs (1iquid and solid) 
- inclusion of ILLW with HLLW

- canister costs

- type of storage, air or water, and

- government facility charges and requirements for terminal storage.

The impact of these factors on absolute costs must be considered before the reprocessor can decide the best solidification route.

The reprocessor would need a firm commitment to a program change since a 5 to $10 \mathrm{yr}$ lead time is required to put a reprocessing plant on line. As will be shown later, the waste storage scenarios (i.e., salt mine or RSSF) will be a major factor in all cases of waste solidification options.

\subsection{U.S. ARMY}

The Army's main concern in this program is with economics - to develop an alternative energy source for thermal systems that is cost competitive with fossil fuel systems. It is also their objective to provide an overall benefit to the nuclear fuel cycle by providing storage for canisters in a secure facility (U.S. Army installation). One potential limitation to Army use of the canisters is that it cannot compete with private industry in providing a service or product. This should not be a factor, however, since present plans call for storage by the government once a canister leaves the fuel reprocessor.

\subsection{ENERGY RESEARCH AND DEVELOPMENT ADMINISTRATION (ERDA)}

ERDA is a research and development organization through which the government sponsors and disseminates relevant energy-related work. In the nuclear industry, emphasis has been on closing the fuel cycle by providing for the operation of reprocessing plants to recover uranium and plutonium from spent fuel and management of the wastes generated. This work can be independent or can be in conjunction with a commercial fuel reprocessor.

A major ERDA role in the nuclear fuel cycle is to provide at least one alternative for waste solidification. This very likely will include joint 
ERDA-reprocessor involvement in the initial waste solidification process operated at a U.S. commercial reprocessing plant.

\subsection{NUCLEAR REGULATORY COMMISSION (NRC)}

The NRC is a government agency designed to initiate, enforce, and update regulations for nuclear-related activities. All upcoming regulations and reviews in the waste management area will be "first of a kind" since no commercial waste solidification plant has ever been operated in the U.S. The reprocessor must adhere to all rules concerning waste disposal. The dilemma occurs in that the regulations are likely to change as more actual data is put into the system, and anticipating these changes is difficult. Increased public concern with the safety and environmental aspects must also be anticipated. Lengthy hearings to resolve such matters, whether justified or not, will be a matter of course.

\subsection{NUCLEAR RESEARCH AND APPLICATIONS (NRA)}

The NRA is a Division of ERDA which is funding part of the program dealing with heat transfer and boiler design since this can be used in general isotope applications in thermal systems (general thermal design). A major division objective is to study and promote the beneficial use of waste fission products. Besides bulk waste canister applications, a number of potential uses for certain separated fission products (such as ${ }^{90} \mathrm{Sr}$ for heat sources and ${ }^{137}$ Cs for radiation sources) have been identified. NRA is currently developing systems and studying markets for these fission products to allow input for future ERDA/NRC decisions concerning nuclear waste management. 
3.0 FORECAST OF SOLIDIFIED WASTE SUPPLY 

1 


\subsection{FORECAST OF SOLIDIFIED WASTE SUPPLY}

The forecast of waste supply from the Light Water Reactor (LWR) fuel cycle for the period 1981 to 2004 was based on the following assumptions:

- Plutonium recycle will begin in 1981.

- Uranium recycle will begin in 1980.

- Fuel burnup will be 33,000 MWd/MTHM. (a)

- LWR fuel will be reprocessed 150 days out of reactor.

- HLLW contains essentially all of the nonvolatile fission products, $0.2 \%$ of uranium and plutonium initially in spent fuel, and all other actinides formed from uranium and plutonium transmutation in the reactors.

- Typical calcined waste production will be $75 \mathrm{~kg} /$ MTHM and have a density of $2 \mathrm{~g} \mathrm{calcine} / \mathrm{cm}^{3}$ (volume of solidified waste is $3.75 \times 10^{4} \mathrm{~cm}^{3} /$ MTHM).

- Typical waste canisters will be between 30 and $61 \mathrm{~cm}$ in diameter, and 305 to $457 \mathrm{~cm}$ long.

- The initial fuel reprocessor plant (FRP) startup will be 1979 and waste solidification will begin after $2 \mathrm{yr}^{(b)}$ of operations.

Other details are presented in Appendix A (Bases for Projections of Capacity, Material Flows, and Waste Generation Involving LWRs). ${ }^{(8)}$ The information contained in Appendix $A$ has slightly different bases such as the upper waste volume 1 imit $\left(6 \times 10^{4} \mathrm{~cm}^{3} /\right.$ MTHM), initial FRP startup in 1977, and shipment of 10-yr-old solidified waste to a federal repository.

Table 3.1 (based on Table A-3) summarizes the predicted amount of solidified waste available as a function of time. Initially, the waste age will be relatively old (about 5 to $10 \mathrm{yr}$ ) as FRPs are started up and older fuel is reprocessed first. Eventually (possibly in 1983), the waste may be solidified at an earlier age (about $2-y r$-old waste may be practical). The heat generation rate of 10-, 5-, and 2-yr-0ld waste is about 1.1, 2.0, and $5.8 \mathrm{~kW} / \mathrm{MTHM}$, respectively. The waste characteristics, canister sizes, and thermal characteristics are discussed in later sections.

(a) Megawatt day/Metric tonne heavy metal.

(b) This could be as long as $5 \mathrm{yr}$. 
TABLE 3.1. Forecast of Solidified Waste Supply

\begin{tabular}{|c|c|c|}
\hline Year & $\begin{array}{l}\text { LWR Fuel } \\
\text { Reprocessed } \\
\text { (MTHM) (a) }\end{array}$ & $\begin{array}{l}\mathrm{kg} \times 10^{-4} \\
\text { Calcine } \\
\text { Waste (b) } \\
\end{array}$ \\
\hline 1981 & 500 & 3.75 \\
\hline 1982 & 1,000 & 7.50 \\
\hline 1983 & 1,500 & 11.25 \\
\hline 1984 & 1,800 & 13.50 \\
\hline 1985 & 2,100 & 15.75 \\
\hline 1986 & 2,100 & 15.75 \\
\hline 1987 & 2,600 & 19.50 \\
\hline 1988 & 3,100 & 23.25 \\
\hline 1989 & 3,100 & 23.25 \\
\hline 1990 & 4,100 & 30.75 \\
\hline 1991 & $5,027.5$ & 37.71 \\
\hline 1992 & $4,965.4$ & 37.24 \\
\hline 1993 & $5,577.8$ & 41.83 \\
\hline 1994 & $6,250.3$ & 46.88 \\
\hline 1995 & $6,961.0$ & 52.21 \\
\hline 1996 & $7,719.4$ & 57.90 \\
\hline 1997 & $8,515.0$ & 63.86 \\
\hline 1998 & $9,314.4$ & 69.86 \\
\hline 1999 & $10,153.8$ & 76.15 \\
\hline 2000 & $10,975.9$ & 82.32 \\
\hline 2001 & $11,744.9$ & 88.09 \\
\hline 2002 & $12,515.3$ & 93.86 \\
\hline 2003 & $13,267.7$ & 99.51 \\
\hline \multirow[t]{2}{*}{2004} & $14,044.8$ & 105.34 \\
\hline & TOTAL & $1.117 \times 10^{3}$ \\
\hline
\end{tabular}

(a) Beginning in 1979; 2-yr lag time between waste generation and solidification assumed.

(b) Basis: $75 \mathrm{~kg}$ calcine/MTHM.

Table 3.1 and the tables in Appendix $A$ are presented as a point of reference. Due to the uncertainties such as final waste form, fuel reprocessor startup, and age of fuel reprocessed, alternatives are available which may provide an overall benefit to the nuclear fuel cycle including Army canister usage. Details of the present strategy and alternative strategies follow. 
4.0 PRESENT WASTE SOLIDIFICATION STRATEGY 



\subsection{PRESENT WASTE SOLIDIFICATION STRATEGY}

The present strategies wi11 be based on existing commercial reprocessing facilities in New York (Nuclear Fuel Services) and South Carolina (Allied-General Nuclear Services). The discussion has been divided into sections on solidification processes and canister characteristics.

\subsection{SOLIDIFICATION PROCESSES}

Nuclear Fuel Services

Nuclear Fuel Services Inc. (NFS) located at West Valley, New York was planning to convert their high-level waste to a borosilicate glass form. The process would include calcination (spray calcination with fluidized bed calcination as alternate) and vitrification (in-can melting) steps. (9) A typical process of this type is schematically shown in Figure 4.1. The future of this plant is now uncertain $(10)$ and it may never again operate as a fuel reprocessing plant. However, the plans for waste solidification will be included here as an example.

The expected plant startup date was about 1983. The design basis fue? burnup was about 33,000 MWd/MTHM. The waste age for the first 10 years of operation was expected to be 5 years out of reactor on the average while the subsequent 10 to 40 year period would have handled 2 to 5 year old waste. It was expected that the oldest fuel in the basin would be reprocessed first. The plant would have been licensed to handle waste 2 or more years out of reactor.

The plant design capacity is $750 \mathrm{MTHM} / \mathrm{yr}$. It was planned that canisters will be stored in water for a few years after vitrification prior to shipment to a federal repository.

\section{Allied-General Nuclear Services}

Allied-General Nuclear Services (AGNS) is presently building a reprocessing plant at Barnwell, South Carolina. The waste handling facilities are being constructed up to the point of liquid storage. Although waste solidification plans have not been annnounced to date, evaluation of the 


\section{SPRAY CALCINER/IN-CAN MELTER PROCESS}

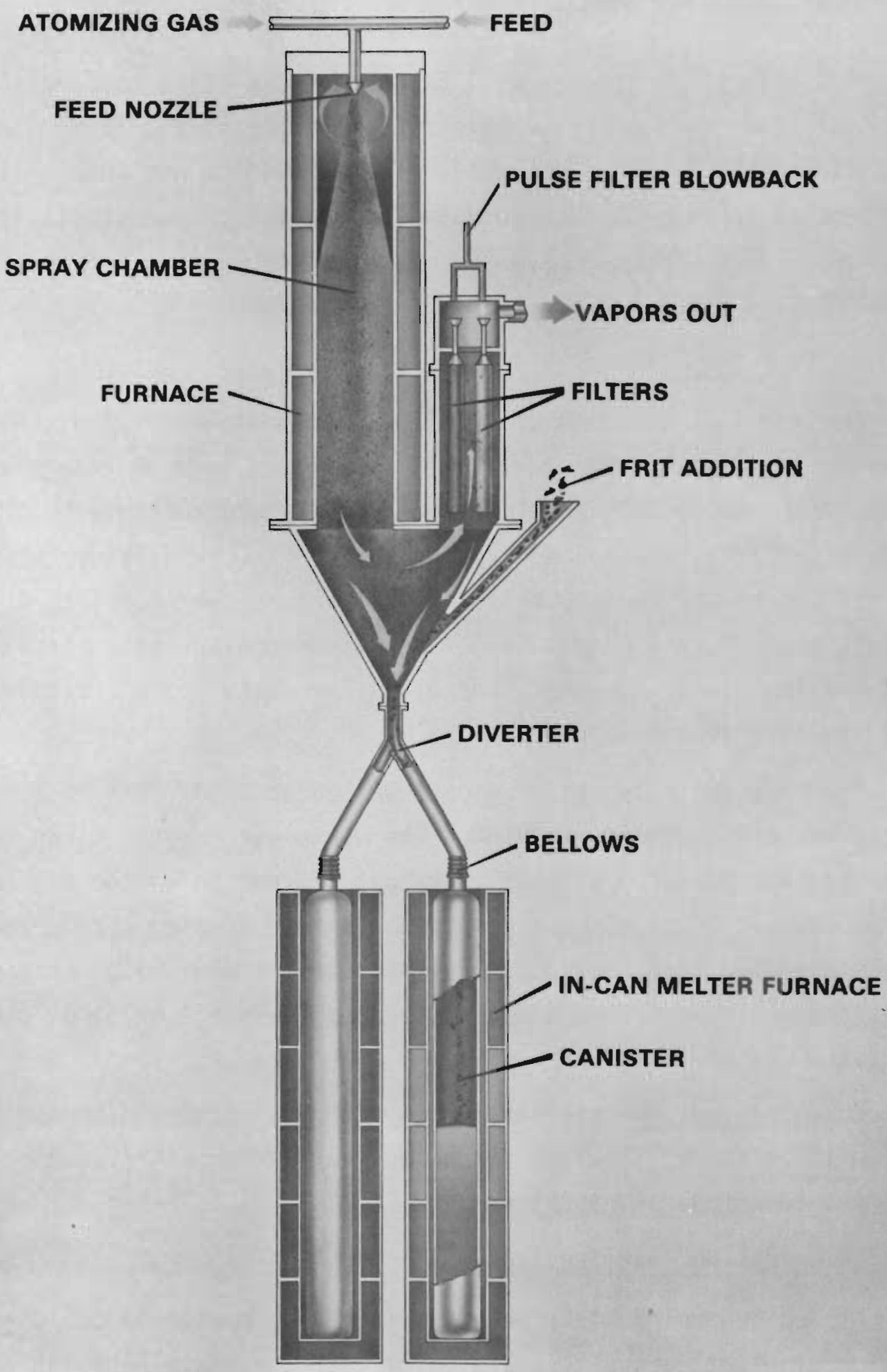

FIGURE 4.1. Spray Calciner/In-Can Melter Process 
solidification method is continuing. A fluidized bed process has been considered for producing calcine, a rotary kiln calciner - metallic melter ("French Process," see below), or spray calcination and in-can melting for producing a vitrified product. Most likely a vitrified product will be produced.

Projected startup for the AGNS FRP is approximately 1979. Some type of solidification would then have to occur within $5 \mathrm{yr}$ since liquid storage facilities provide only 2 to $3 \mathrm{yr}$ of storage. (11) Plant capacity is expected at $1500 \mathrm{MTHM} / \mathrm{yr}$ with design basis fuel of 33 to 35,000 MWd/MTHM. Specific rates for the first few years of operations and age of waste can only be speculated.

The "French Process"

This process (rotary kiln calciner-melter) is being developed at the Marcoule Nuclear Research Center in France. The full-size rotary kiln has a capacity to calcine about 30 to $40 \mathrm{l} / \mathrm{hr}$ of liquid HLLW. Increased capacity would have to be by preconcentration or use of parallel process lines. The kiln would feed calcine into one or more melters, either an inductionheated inconel (metallic) or induction-heated ceramic type. The melt would drain through freeze valves into the carister.

The process has been extensively tested and equipment reliability can be predicted with good accuracy. When applied to United States reprocessing needs, however, the process has some disadvantages. Since maximum capacity is about 2 MTHM/day, several process lines would be required. Also, frequent melter replacements would be required. At this time it does not seem likely that United States reprocessors will use this low capacity system.

\subsection{WASTE CANISTER CHARACTERISTICS}

Spray Calcination/In-Can Melting Process

A waste solidification process similar to that proposed for NFS would generate canisters up to $57 \mathrm{~cm}$ in diameter with $274 \mathrm{~cm}$ of glass fill (see Figure 4.2). The thermal output from this size canister based on the years since the fuel was discharged from the reactor is shown on Figure 4.3. 


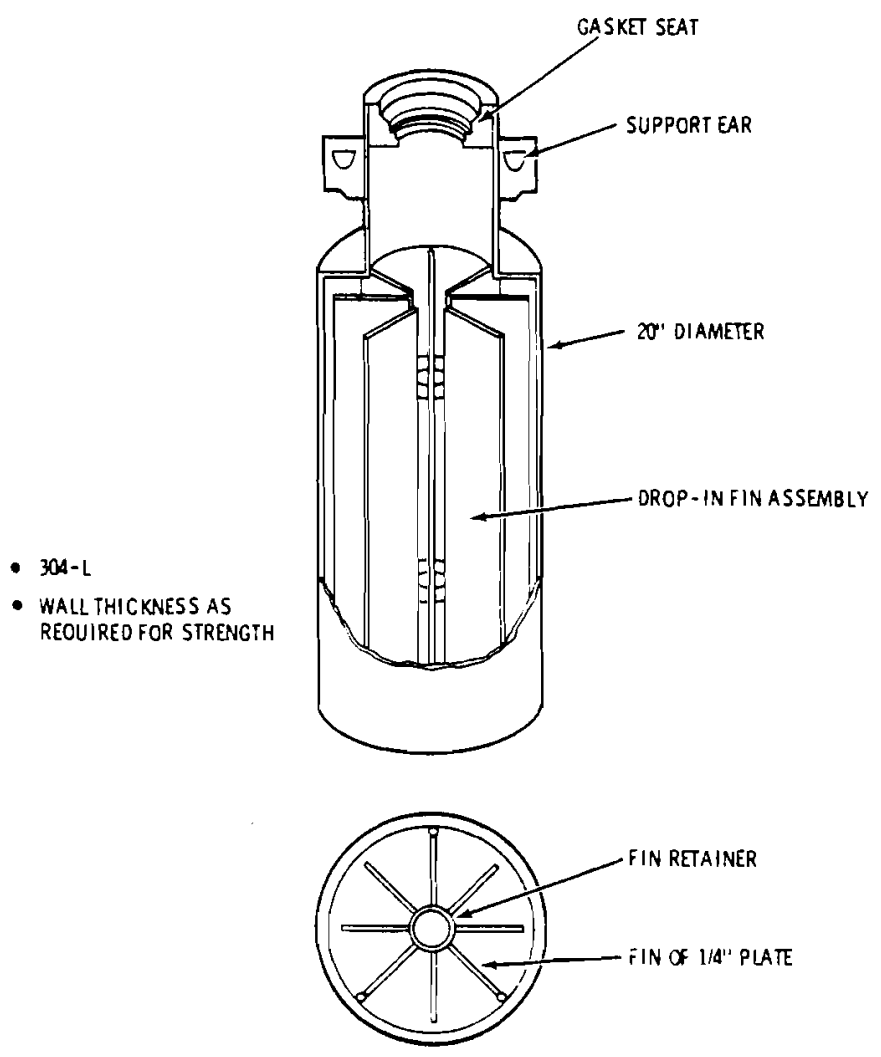

FIGURE 4.2. Typical In-Can Melter Canister

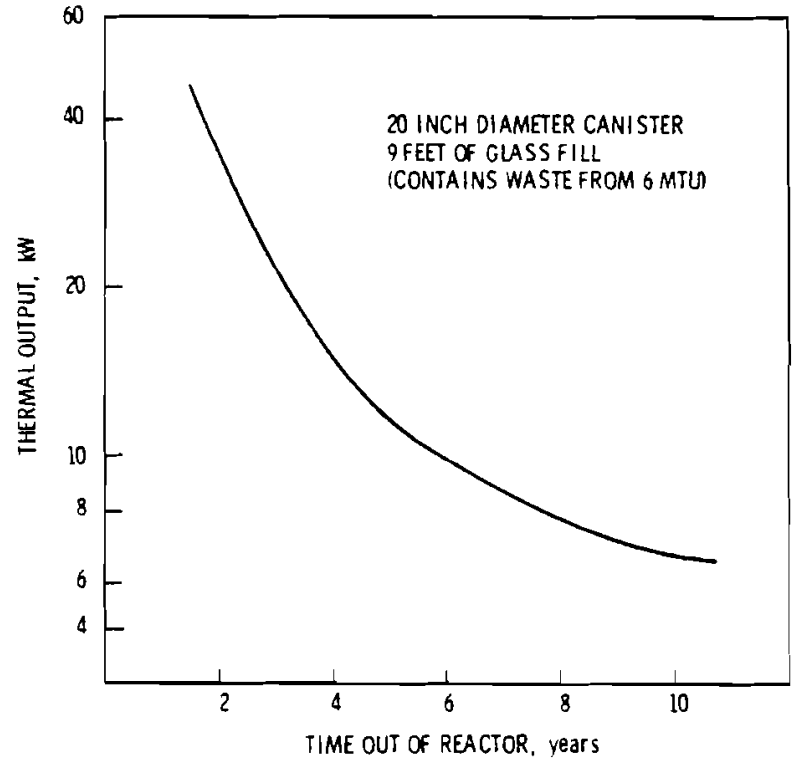

FIGURE 4.3. Thermal Output of Canister 
The maximum allowable canister diameter can be based on the permissible centerline temperature; a temperature of $800^{\circ} \mathrm{C}$ is considered an upper limit. The use of fins allows more waste (i.e., larger diameter) to be incorporated in a canister. For example, 1-yr-old waste can be put in a 46-cm diameter (18-in.) can with fins, compared to a $28-\mathrm{cm}$ diameter (11-in.) can without fins. The proposed NFS process includes a canister with fins intended to handle the waste thermal loading at $2 \mathrm{yr}$ out of reactor. The allowable canister diameter for wastes at different ages is shown in Figure 4.4. Included is the estimated improvement in waste loading for a finned canister containing borosilicate glass. Heat generation characteristics for vitrified waste from other processes at other reprocessing plants would be quite similar to that shown in Figure 4.4 .

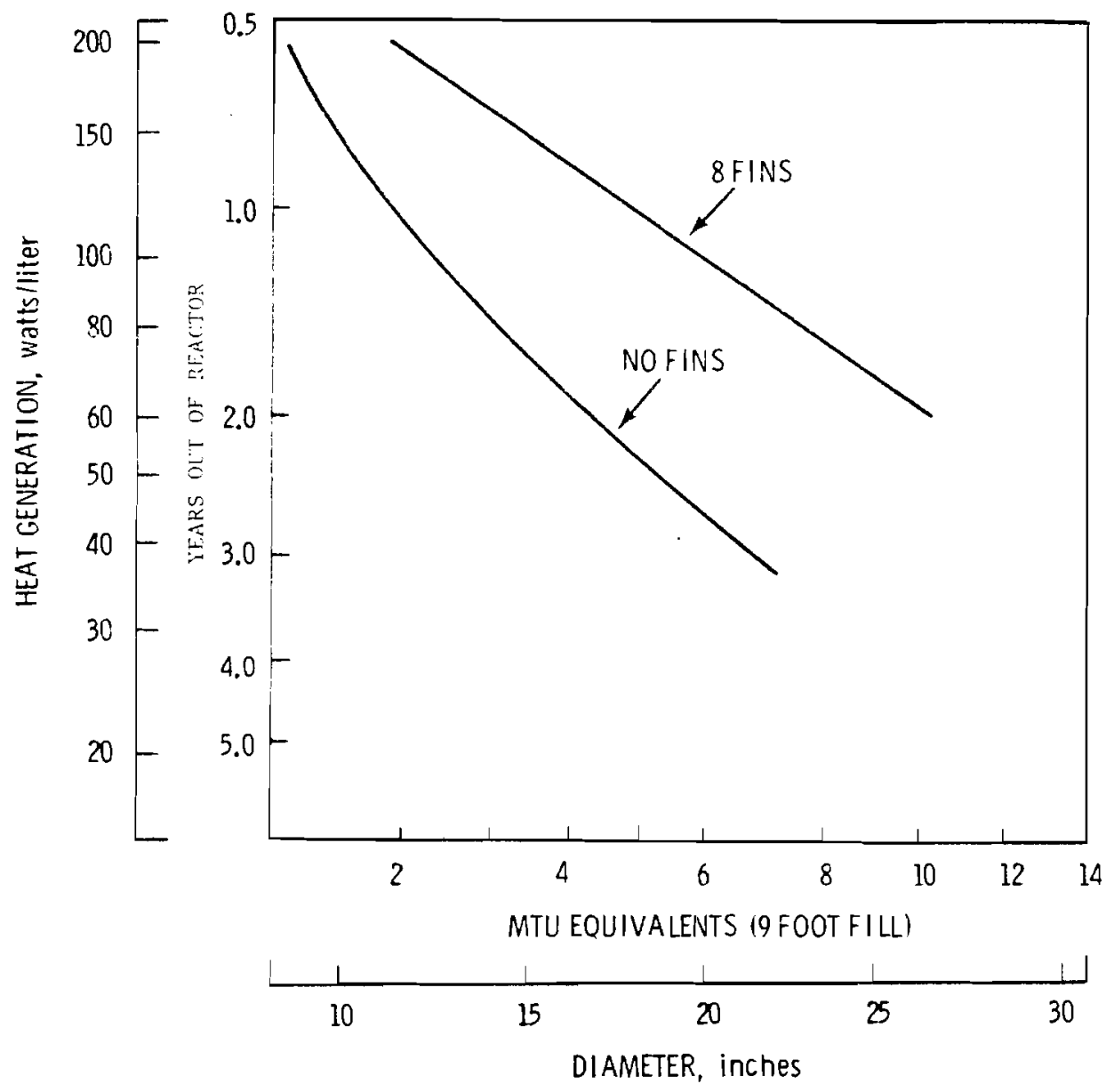

FIGURE 4.4. Allowable Canister Diameter $\left(800^{\circ} \mathrm{C}\right.$ Centerline When Air Convection/Radiation Cooled) 
1

.

: 


\subsection{ALTERNATE SOLIDIFICATION STRATEGIES AND PROCESSES}


1.

.

: 


\subsection{ALTERNATE SOLIDIFICATION STRATEGIES AND PROCESSES}

Any alternate strategies will have to fall within government regulations (i.e., the waste must be chemically, thermally, and radiolytically stable, and the canister must meet terminal storage facility requirements). Present regulations for final storage will likely be the limiting criteria for waste solidification and will be clearly shown to affect advanced solidification processes.

Many alternatives are available in waste solidification including different product forms, blending old and new waste, and even different process steps. For steam plant use, it would seem that putting the maximum amount of waste in the fewest number of canisters (to decrease total plant and canister capital investment) at the earliest date (to take advantage of initial high heat generation rates for steam production) would be economically attractive. Technical limitation on waste loading canisters is primarily in the thermal content or, more specifically, the centerline and surface temperatures. The kilowatts of thermal energy in the waste from each metric ton of fue? processed is plotted against the years since the fuel was discharged from the reactor in Figure 5.1. Thermal use of the canisters would require early solidification; about $2-y r-01 d$ waste is considered practical.

Also shown in Figure 5.1 is the effect of removing the strontium and cesium from the waste, and the combined and separated thermal decay characteristics of these elements (the heat generated by the separated ${ }^{90} \mathrm{Sr}^{\prime} \mathrm{s}$ short-lived daughter $90_{Y}$ is also removed). The separation may become desirable if the potential applications under consideration by NRA for these elements become economically feasible (strontium as a heat source and cesium as an irradiation source). The heat generation of the remaining waste would be reduced by about $28,42,76,90$, and continuing at $90 \%$ at $1,2,5,10$ and greater than 10 years waste age, respectively. The reduction in volume and mass would be about $9 \%$ (based on mass of strontium, yttrium, and cesium/MTHM divided by total mass of actinides and fission products/MTHM). Thus, the waste in canisters would not produce as much heat which would be disadvantageous for Army use (more canisters and capital investment required for 
equivalent thermal output). This does not preclude the economical application of the canisters in thermal systems at this time.

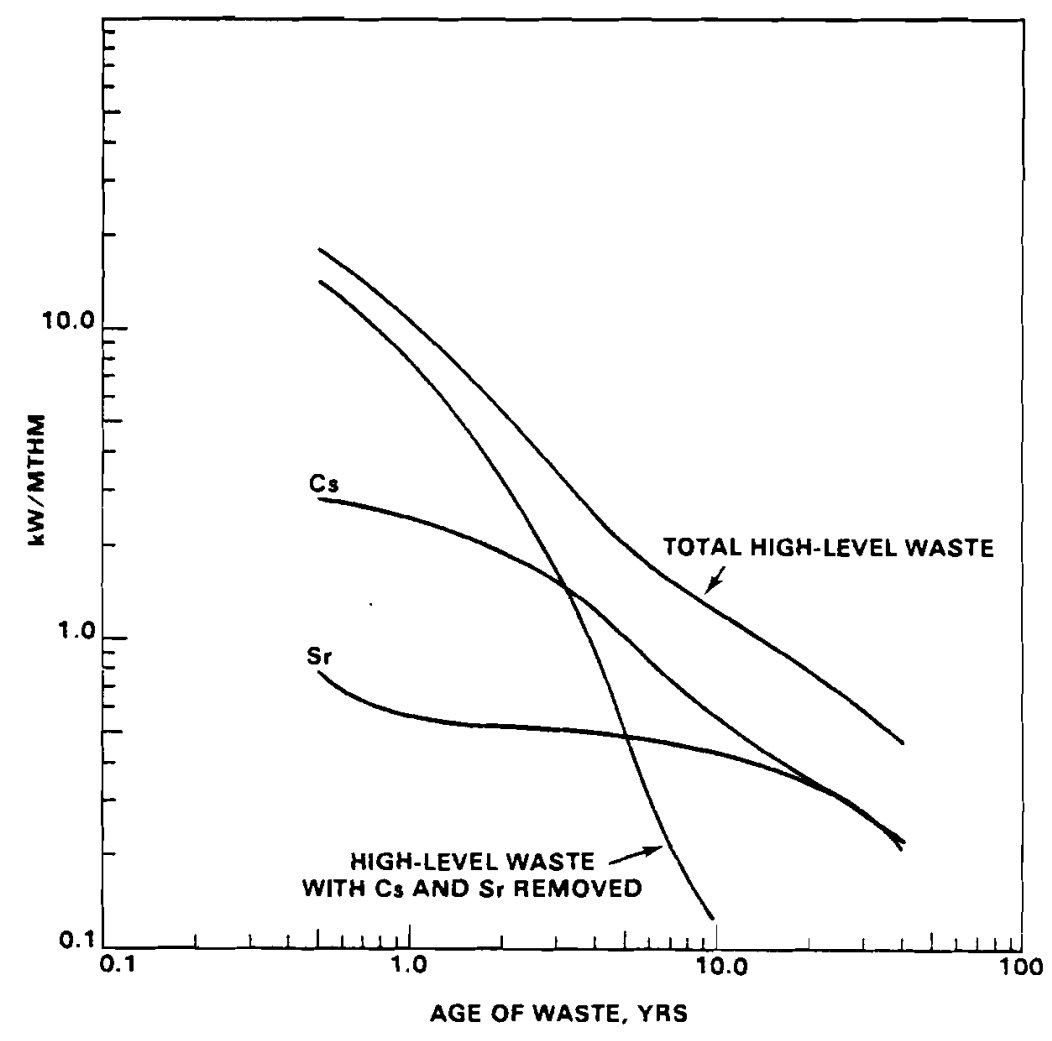

FIGURE 5.1. Thermal Decay of HLLW, Strontium, and Cesium $(33,000 \mathrm{MWd} / \mathrm{MTHM}$ - $30 \mathrm{MW})$

Canister characteristics and waste form relationships were considered by assuming that the canister is an infinitely long cylinder; the following equation applies:

$$
Q=\frac{16 K(T c-T w)}{D^{2}},\left(Q=g \rho_{W}\right)
$$

where $T C=$ center 1 ine temperature $\left({ }^{\circ} \mathrm{C}\right)$

$\mathrm{T}_{\mathrm{W}}=$ wal1 temperature of $\mathrm{cy} 1 \mathrm{inder}\left({ }^{\circ} \mathrm{C}\right)$

$Q=$ volumetric heat generation rate $\left(W / \mathrm{cm}^{3}\right)$

$D=$ canister diameter $(\mathrm{cm})$

$\mathrm{K}=$ product therma 1 conductivity $\left(\mathrm{W} / \mathrm{cm}^{\circ} \mathrm{C}\right)$

$\mathrm{g}=$ mass heat generation rate $(\mathrm{W} / \mathrm{gm})$

$\rho_{W}=H L L W$ mass concentration in product $\left(\mathrm{gm} / \mathrm{cm}^{3}\right)$ 
Equation (1) shows the important influence of thermal conductivity on the heat generation rate of the product for a given diameter and temperature difference. The heat loadings expressed in kilowatts per meter height of the canister is given by:

$$
S=\frac{Q \pi D^{2}}{4} \quad S[=] \mathrm{kW} / \mathrm{M}
$$

Combining Equations (1) and (2) gives the maximum heat loading, Smax, for a particular maximum temperature difference,

$$
S \max =4 \pi K(T C-T w)_{\max }
$$

which gives maximum heat loading as a function of two parameters specifically related to waste form $\left[K\right.$ and $\left.(T c-T w)_{\max }\right]$.

Using data from Tables 5.1 and 5.2 the heat loading has been plotted against canister diameter in Figure 5.2. Plots are shown for calcine, borosilicate glass, borosilicate glass in finned canisters (the most likely form for near term solidification), calcine incorporated in a metal matrix, and glass forms in a metal matrix; the maximum heat loading, $S_{\text {max }}$, is shown for each waste form. These curves are based on 2-yr-old waste stored with a wall temperature of $200^{\circ} \mathrm{C}$. This temperature would correspond to about the same conditions as in a steam plant generating $350^{\circ} \mathrm{F}\left(176^{\circ} \mathrm{C}\right)$ steam.

\begin{tabular}{|c|c|c|c|c|c|}
\hline \multirow[b]{2}{*}{$\begin{array}{l}\text { Years } \\
\text { Out of } \\
\text { Reactor } \\
\end{array}$} & $\begin{array}{c}\text { Mass Heat } \\
\text { Generation } \\
\text { Rate } \\
\end{array}$ & \multicolumn{4}{|c|}{$\begin{array}{c}\text { Volumetric Heat Generation Rate } \\
\text { (Watts/cc) }\end{array}$} \\
\hline & $\begin{array}{l}\text { Watts } / \mathrm{gm}(\mathrm{a}) \\
0.75 \mathrm{~kg} / \mathrm{MTHM}\end{array}$ & Calcine & $\begin{array}{l}\text { Calcine- } \\
\text { Metal } \\
\text { Matrix } \\
\end{array}$ & $\begin{array}{l}\text { Borosilicate } \\
\text { Glass } \\
\end{array}$ & $\begin{array}{c}\text { Borosilicate } \\
\text { Glass-Metal } \\
\text { Matrix } \\
\end{array}$ \\
\hline $\begin{array}{l}0.41 \\
1 \\
2 \\
3 \\
5 \\
7 \\
10 \\
20 \\
40 \\
100\end{array}$ & $\begin{array}{l}0.276 \\
0.145 \\
0.077 \\
0.048 \\
0.026 \\
0.019 \\
0.015 \\
0.0105 \\
0.0064 \\
0.0015\end{array}$ & $\begin{array}{l}0.552 \\
0.290 \\
0.154 \\
0.056 \\
0.052 \\
0.038 \\
0.030 \\
0.021 \\
0.013 \\
0.0030\end{array}$ & $\begin{array}{l}0.406 \\
0.213 \\
0.113 \\
0.071 \\
0.038 \\
0.028 \\
0.022 \\
0.015 \\
0.0094 \\
0.0022\end{array}$ & $\begin{array}{l}0.254 \\
0.133 \\
0.071 \\
0.044 \\
0.024 \\
0.018 \\
0.014 \\
0.0096 \\
0.0050 \\
0.0014\end{array}$ & $\begin{array}{l}0.127 \\
0.067 \\
0.036 \\
0.022 \\
0.012 \\
0.0087 \\
0.0069 \\
0.0048 \\
0.0029 \\
0.0007\end{array}$ \\
\hline
\end{tabular}

\section{TABLE 5.1. Waste Heat Generation Rates}

(a) Watts per gram of calcine waste assuming an average value between typical NFS and AGNS proposed waste compositions. 
TABLE 5.2. Product Properties

Product Form

Calcine

Borosilicate Glass

Calcine-Metal Matrix

Borosilicate Glass

with 8 fins

Borosilicate Marbles

in Metal Matrix
$K$
$\left(w / \mathrm{cm}^{\circ} \mathrm{C}\right)$$\quad \stackrel{\mathrm{D}^{\mathrm{W}}}{\left(\mathrm{C}^{\mathrm{C}} \mathrm{C}\right)}$

0.0029

2.0

0.012

0.92

0.32

1.47

$0.030^{(a)}$

0.92

$0.46^{(b)}$

(a) Estimate.

(b) Assumes $50 \%$ glass form.

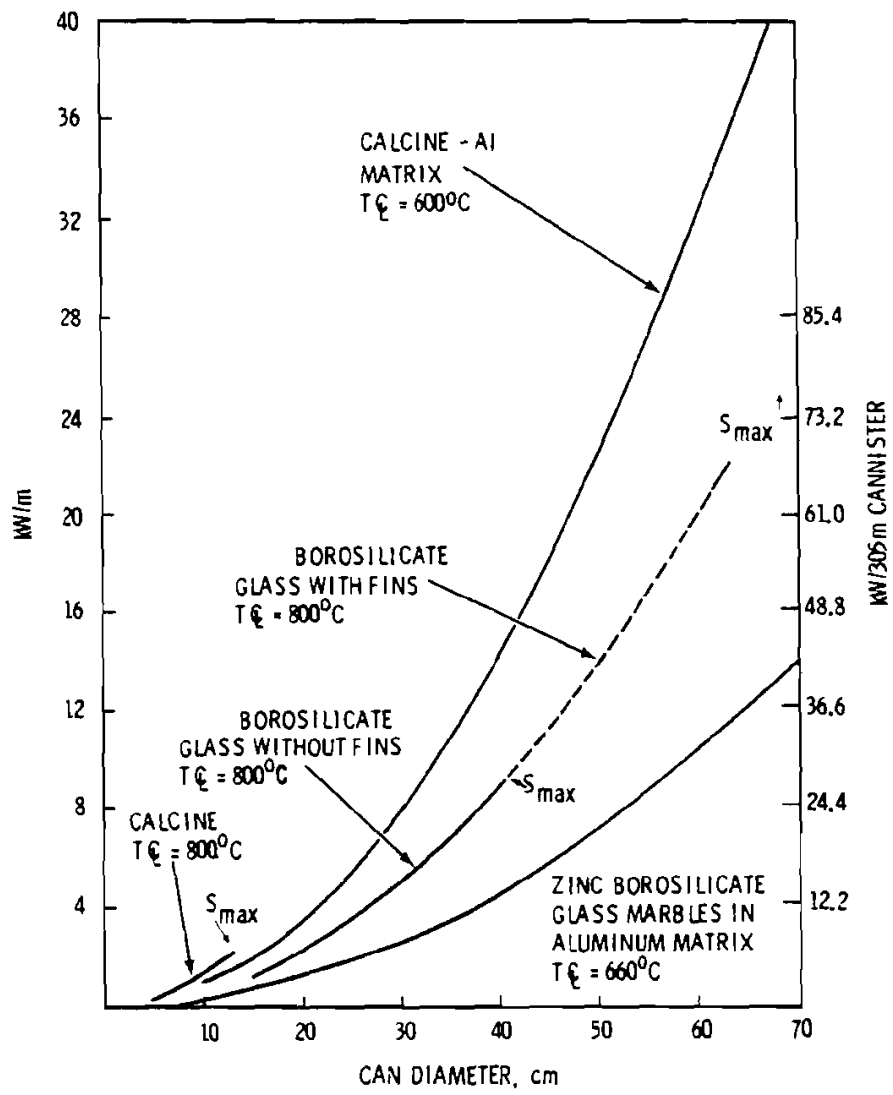

FIGURE 5.2. Heat Loading of 2-yr-old waste when Stored at Canister Wall Temperature of $200^{\circ} \mathrm{C}$ 
The economic tradeoffs for various waste forms are influenced by thermal conductivity, waste density, and temperature limits. It would be economically advantageous to have large canisters (high thermal conductivity) and high waste density to reduce total capital investment for canisters. In Figure 5.2, the number of required canisters is indicated by $\mathrm{kW} / \mathrm{can}$, since the $1 \mathrm{~kW}$ indicates a certain amount of 2-yr-old waste (in this case $13 \mathrm{~kg}$ waste/kW). On these bases, the "best" forms can be rated in decreasing order: calcine-Al matrix, borosilicate glass with fins, borosilicate glass without fins, borosilicate-Al matrix, and calcine.

Storage and use of calcine would require many small canisters. The product most likely produced by initial reprocessors, borosilicate glass in finned cans, (a) allows one to put a significant amount of waste in large canisters. From the standpoint of maximum heat loading, a very attractive process would be putting calcine in a metal matrix. Although not likely to be developed for a few years, it has the advantage of improving thermal conductivity. Borosilicate marbles in an aluminum (b) matrix offer great safety characteristics (low fission product solubility) and high thermal conductivity, but the waste density is relatively low (large canisters but also more of them). Other waste forms being considered by Eurochemic Co., Belgium, are discussed in Reference 13.

To better understand waste loading per canister and to be able to compare different product forms, a graph (Figure 5.3) has been made based on a rearrangement of Equation (1) into a form which equates the factors that are dependent on product characteristics and those controllable by design.

$$
(T c-T w) k=\frac{g \rho_{w} D^{2}}{16}
$$

The mass heat generation rate $g$ is dependent upon the type of waste produced and the age (time out of reactor). Plotted on the left abscissa is $(T c-T w) K$ in watts/cm and on the right is canister diameter in $\mathrm{cm}$. The ordinate shows the amount of waste contained in a canister per unit length

(a) Process being developed by Battelle-Northwest.

(b) Considered the most likely metal to be used. 


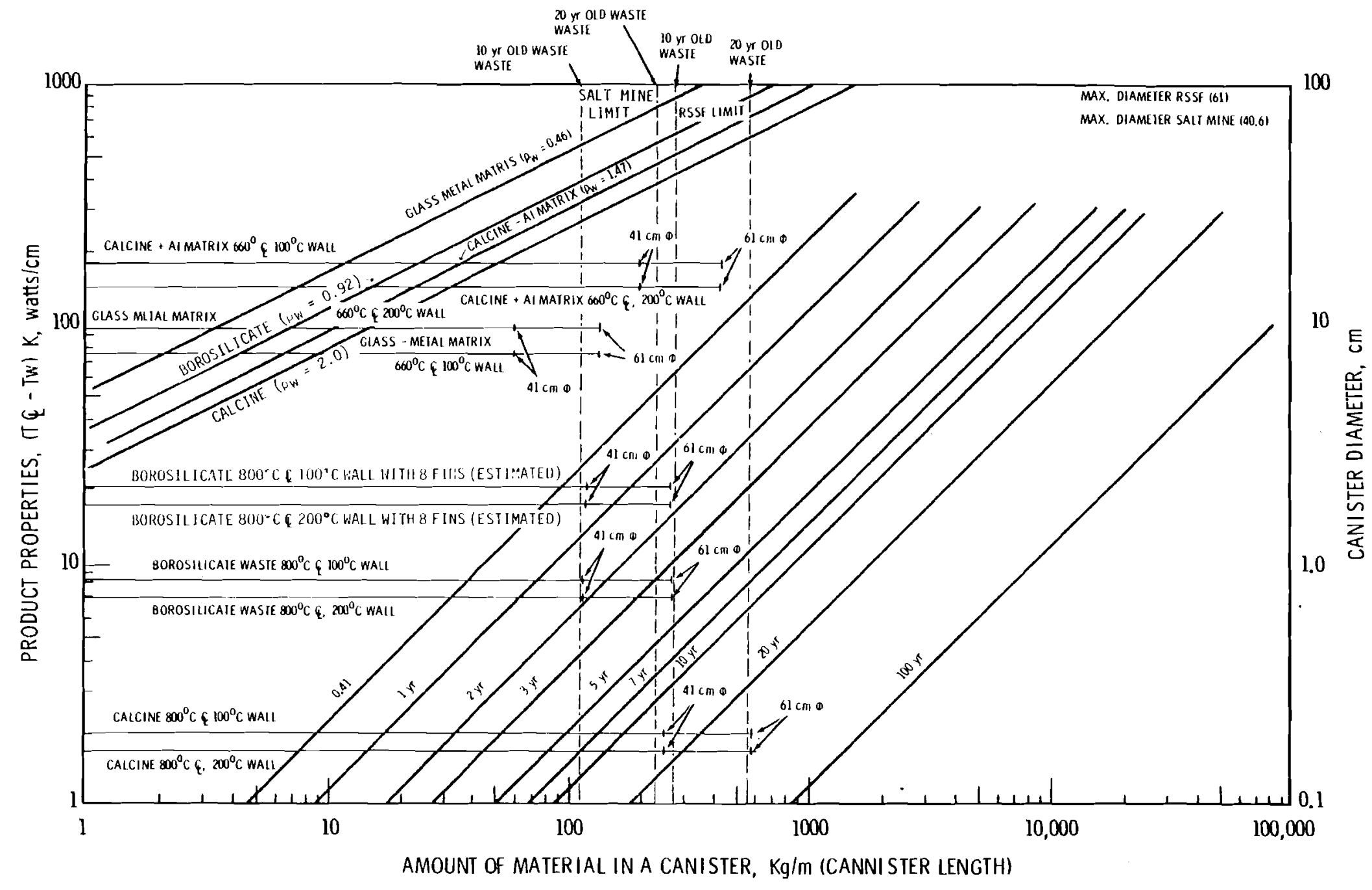

FIGURE 5.3. Comparison of Canister Diameter and Waste Form

(Basis: $75 \mathrm{~kg}$ calcine/MTHM - 33,000 MWd/MTHM - 30 MW) 
$(\mathrm{kg} / \mathrm{m})$. A typical waste $(75 \mathrm{~kg} /$ MTHM at $33,000 \mathrm{MWd} / \mathrm{MTHM})$ was used to plot the heat generation rate (1eft abscissa) at specific times out of the reactor (see Table 5.2) as a function of waste loading (ordinate). Also plotted are the canister diameter (right abscissa) as a function of waste form and waste loading of the canister (ordinate). These plots are based on physical limitations such as densities, heat generation rates of pure waste, and canister diameter. The horizontal plots of ( $T C-T W) K$ represent the thermal limitations for certain temperatures and waste form (thermal conductivity). This figure allows the comparison between canister size, waste form, waste age, and thermal limitations. For example, assume this waste was to be stored in a water basin as calcine $2 \mathrm{yr}$ out of the reactor, let $\mathrm{Tc}=800^{\circ} \mathrm{C}$, $T w=100^{\circ} \mathrm{C}, K=0.0029 \mathrm{~W} / \mathrm{cm}^{\circ} \mathrm{C}$ then $(T \mathrm{C}-T w) K=2.03$. The figure shows that no more than $33 \mathrm{~kg} / \mathrm{m}$ can be placed in the canister. Using the sloped lines in the upper left and the right hand abscissa, the canister diameter $14.5 \mathrm{~cm}$ is determined.

Figure 5.3 is very useful for comparing product forms and noting the impact various constraints have. The most restrictive restraints, as noted earlier, may likely come from the terminal storage facility. As of March 1976 personnel at Sandia Laboratories felt that salt mine storage may provide the following restrictions on waste canisters while RSSF limits are less restrictive. (5)

\begin{tabular}{lcll} 
& Salt Mine Storage & & RSSF \\
${$\cline { 2 - 2 }$} }$ & $305 \mathrm{~cm}$ & & $457 \mathrm{~cm} \max$. \\
Diameter & $40.6 \mathrm{~cm}$ & $67 \mathrm{~cm}$ \\
Wa11 Temperature & $250^{\circ} \mathrm{C}$ & $427^{\circ} \mathrm{C}(\mathrm{a})$ \\
Heat Loading & $5 \mathrm{~kW}$ & $13 \mathrm{~kW}$ (depends on can size)
\end{tabular}

(a) During normal operation.

Other preliminary salt mine criteria indicated that the heat loading could be as high as $7 \mathrm{~kW} .{ }^{(8)}$ More recent analyses (January 1977) at Sandia Laboratories, in conjunction with the conceptual design of the Waste Isolation Pilot Plant, indicate that the maximum heat loading may be $3.5 \mathrm{~kW}$ for 
a doubly contained $40.5 \mathrm{~cm}$ OD canister; the internal diameter is $33.3 \mathrm{~cm}$. The results presented in this report are based on a $5 \mathrm{~kW}$ maximum heat loading. The impact on the results of reducing this to $3.5 \mathrm{~kW}$ is discussed in Section 10.5, "Overall Economics".

The proposed shipping regulations state that solidified waste must be shipped to a federal repository no later than $10 \mathrm{yr}$ after fuel dissolution. This waste will then be between 10- to 20-yr out of reactor assuming inmediate dissolution and a maximum 10-yr fuel storage. The limits the Salt Mine and RSSF place on the canisters at the time they would be shipped to the final storage facility are shown as the two vertical bands enclosed by dotted lines on Figure 5.3.

Potential waste forms have been plotted as horizontal lines (Figure 5.3) according to centerline temperature limitations $\left(660^{\circ} \mathrm{C}\right.$ for metal matrix forms and $800^{\circ} \mathrm{C}$ for calcine and glass forms) and both 100 and $200^{\circ} \mathrm{C}$ wall temperatures. The wall temperatures approximate two methods of canister storage in water (water basin and pressurized steam boiler) before shipment to the federal storage site. The information presented in Figure 5.3 can be summarized as follows:

- The limiting factors for the metal matrix forms are not thermal conductivity, but density. Earlier waste (earlier than $0.4 \mathrm{yr}$ ) could be solidified and stored in water within temperature limitations. The salt mine and RSSF heat loads and canister size limits with both $10-$ and 20-yr-old waste could easily be met by the glass-metal matrix. But, the calcine-metal matrix canister would require a canister diameter less than 41 and $61 \mathrm{~cm}$ to meet the 10-yr-old waste salt mine and RSSF heat load limits, respectively.

- Both the borosilicate and borosilicate with fins allow solidification to occur before 2-yr-old waste age for water storage and also meet the 10- and 20-yr-old waste salt mine limitations. Fins allow less than $1-y r-01 d$ waste to be solidified and stored in water. For the RSSF limits $(61 \mathrm{~cm}$ diameter can), fins allow slightly less than 2-yr-old waste to be solidified, stored in water, then shipped to the RSSF at a 
waste age of $10 \mathrm{yr}$. Without fins, 2-yr-01d waste would require a canister of about a $41 \mathrm{~cm}$ dia to allow water storage and subsequent shipment to the RSSF at 10-yr waste age. A $61 \mathrm{~cm}$ dia canister could meet water storage 1 imits and 10-yr age waste RSSF 1 imits if the waste is solidified at about 4 yr of age.

- Pure calcine would require small diameter canisters to meet both salt mine and RSSF 1 imits at 10- and 20-yr waste age or it could be solidified at ages greater than about 20 yr to meet maximum diameter limits.

The final waste form and canister size is uncertain at this time. Desirable characteristics of the waste are a low leachability of fission products and relatively high thermal conductivity, but the absolute values have yet to be specified. Pure calcine is on the lower end of the spectrum; calcine-metal matrix has the advantage of high thermal conductivity, but the leachability is greater than borosilicate forms. Borosilicate forms have a relatively high thermal conductivity and low leach rate, and also meet preliminary RSSF and salt mine heat load and canister size limits (10-yr and 20-yr waste age) for solidification occurring at 2-yr waste age with water storage for a certain period. Borosilicate-metal matrix would have decreased solubility and increased thermal conductivity when compared to borosilicate alone, but the amount of waste that could be placed in a can would be less.

Based on the above considerations, borosilicate-metal matrix as a final waste form will not be considered for now. Due to its advantages, calcine-metal matrix will be considered as will borosilicate with fins which appears to be the most likely form at this time. Also, calcine with fins will receive attention.

The guidelines for salt mine storage are only guidelines, not regulations. The regulations concerning disposal will not be specific until pilot plant studies of various disposal methods have been at least partially completed. Limits on heat load and canister size should be somewhat variable. Larger heat loads and sizes could possibly be safely stored by placing the 
canisters further apart (increasing capital costs). Thus, if a major economic advantage to the overall fuel cycle can be found with a certain canister size and head load, the disposal site could possibly be designed to accommodate them within certain limits.

One advantage of the RSSF is that its limits are less restrictive for heat load and canister size, however, its existence is uncertain. The present strategy is to have the fuel reprocessors store the waste until the disposal site is ready for service. However, if needed, the RSSF concept could be used.

On the bases discussed, the next section considers various waste forms, canister sizes, Army canister use, and advantages to the fuel cycle. More specific heat transfer analyses including boiler concepts and the influence of these concepts on canister temperature distributions is presented in the section on steam plant design. 
6.0 STRATEGIES FOR ARMY CANISTER USE 
$\therefore$ 


\subsection{STRATEGIES FOR ARMY CANISTER USE}

As a starting point, solidification of 2 -yr-old waste (at the earliest) wi 11 be assumed. A strategy, which includes the economics of the overall fuel cycle and Army canister use, is to eliminate the requirements of an RSSF and large-scale FRP water basin storage. This would require the Army to:

- Accept all canisters including relatively low thermal output canisters while "old" fuel is processed allowing for plant startup and initial operating experience.

- Store the waste canisters until a permanent disposal site is ready for receiving canisters and until the thermal restrictions are met.

Based on the earliest plant startup of 1979 for AGNS and $2 \mathrm{yr}$ of processing at below full capacity and at least 5-yr-old waste, the first 2-yrold waste might be available in 1983 . It may be possible to start processing fuel which is much "fresher" than 5 -yr-old, but during initial plant operation it would be advantageous to operate with the "oldest" fuel first due to lower heat generation rates. If economic incentives are available, it may be possible to provide, at an earlier date, higher heat generating canisters by solidifying a mixture of "fresh" and "old" waste.

Table 6.1 shows the number of canisters produced as a function of time, canister diameter, and waste form (borosilicate and calcine-Al matrix). The bases are the densities presented in Table 5.1 and a canister length of $305 \mathrm{~cm}$. This length would probably be easier to handle at a permanent storage site than a $457 \mathrm{~cm}$ canister. The calcine-Al matrix contains about the same amount of waste in a $30.5 \mathrm{~cm}$ dia canister as a borosilicate $40.6 \mathrm{~cm}$ dia canister. (This is also true for calcine-Al matrix in $40.6 \mathrm{~cm}$ dia canister compared to borosilicate glass in $50.8 \mathrm{~cm}$ dia canister, and calcineAl matrix in $50.8 \mathrm{~cm}$ dia canister compared to borosilicate glass in a $61 \mathrm{~cm}$ dia canister.) The rate of waste generation is based on the information from Table 3.1 . 
TABLE 6.1. Prediction of Waste Canister Availability

\begin{tabular}{|c|c|c|c|c|c|c|c|c|c|c|}
\hline \multirow[b]{4}{*}{ Year } & \multicolumn{10}{|c|}{ Canister Sizes $(z=305 \mathrm{~cm})^{(a)}$} \\
\hline & \multicolumn{3}{|c|}{ Dialleter $=30.5 \mathrm{~cm}$} & \multicolumn{2}{|c|}{ Diameter $=40.6 \mathrm{~cm}$} & \multicolumn{2}{|c|}{ Diameter $=50 . \overline{8} \mathrm{~cm}$} & \multicolumn{3}{|c|}{ Diameter $=61 \mathrm{~cm}$} \\
\hline & \multicolumn{2}{|c|}{$\begin{array}{l}\text { Borosilicate } \\
\text { Glass }\end{array}$} & $\begin{array}{c}\text { Calcine-AT } \\
\text { Matrix }\end{array}$ & $\begin{array}{l}\text { Dorosilicate } \\
\text { Glass }\end{array}$ & $\begin{array}{l}\text { Calcine-AT } \\
\text { Matrix }\end{array}$ & \multicolumn{2}{|c|}{$\begin{array}{ccc}\begin{array}{c}\text { Borosilicate } \\
\text { Glass }\end{array} & \begin{array}{c}\text { Calcine-Al } \\
\text { Matrix }\end{array} \\
\end{array}$} & $\begin{array}{l}\text { Borosilicate } \\
\text { Glass }\end{array}$ & \multicolumn{2}{|c|}{$\begin{array}{l}\text { Calcine-Al } \\
\text { Matrix }\end{array}$} \\
\hline & $\begin{array}{l}\text { Genera - } \\
\text { tion }\end{array}$ & $\begin{array}{l}\text { Accumu- } \\
\text { tion }\end{array}$ & Generation & Accumulation & Generation & Accumulation & Generation & Accumulation & $\begin{array}{l}\text { Genera- } \\
\text { tion } \\
\end{array}$ & $\begin{array}{l}\text { Accumu- } \\
\text { tion } \\
\end{array}$ \\
\hline & 183 & 183 & 114 & 114 & 70 & 70 & 41 & 41 & 29 & 29 \\
\hline 1982 & 366 & 549 & 229 & 343 & 141 & 211 & 83 & 124 & 57 & 86 \\
\hline 1983 & 549 & 1,098 & 343 & 686 & 211 & 422 & 124 & 248 & 86 & 172 \\
\hline 1984 & 659 & 1,757 & 412 & 1,098 & 253 & 675 & 149 & 397 & 103 & 275 \\
\hline 1985 & 768 & 2,525 & 480 & 1,578 & 295 & 970 & 173 & 570 & 120 & 395 \\
\hline 1986 & 768 & 3,293 & 480 & 2,058 & 295 & 1,265 & 173 & 743 & 120 & 515 \\
\hline 1987 & 951 & 4,244 & 594 & 2,652 & 365 & 1,630 & 215 & 958 & 149 & 664 \\
\hline 1988 & 1,134 & 5,378 & 709 & 3,361 & 435 & 2,065 & 256 & 1,214 & 178 & 842 \\
\hline 1989 & 1,134 & 6,512 & 709 & 4,070 & 435 & 2,500 & 256 & 1,470 & 178 & 1,020 \\
\hline 1990 & 1,500 & 8,012 & 938 & 5,008 & 576 & 3,076 & 339 & 1,809 & 235 & 1,255 \\
\hline 1991 & 1,840 & 9,852 & 1,150 & 6,158 & 706 & 3,782 & 415 & 2,224 & 288 & 1,543 \\
\hline 1992 & 1,817 & 11,669 & 1,136 & 7,294 & 698 & 4,480 & 410 & 2,634 & 284 & 1,827 \\
\hline 1993 & 2,040 & 13,709 & 1,275 & 8,569 & 783 & 5,263 & 461 & 3,095 & 319 & 2,146 \\
\hline 1994 & 2,287 & 15,996 & 1,429 & 9,998 & 878 & 6,141 & 516 & 3,611 & 358 & 2,504 \\
\hline 1995 & 2,547 & 18,543 & 1,592 & 11,590 & 978 & 7,119 & 575 & 4,186 & 399 & 2,903 \\
\hline 1996 & 2,824 & 21,367 & 1,765 & 13,355 & 1.084 & 8,203 & 638 & 4,824 & 442 & 3,345 \\
\hline 1997 & 3,115 & 24,482 & 1,947 & 15,302 & 1,196 & 9,399 & 703 & 5,527 & 487 & 3,832 \\
\hline 1998 & 3,408 & 27,890 & 2,130 & 17,432 & 1,308 & 10,707 & 769 & 6,296 & 533 & 4,365 \\
\hline 1999 & 3,715 & 31,605 & 2,322 & 19,754 & 1,426 & 12,133 & 839 & 7,135 & 581 & 4,946 \\
\hline 2000 & 4,016 & 35,621 & 2,510 & 22,264 & 1.542 & & 907 & 8,042 & 628 & 5,574 \\
\hline 2001 & 297 & 39,918 & 2,686 & 24,950 & 1,650 & 15,325 & 970 & 9,012 & 673 & 6,247 \\
\hline 2002 & 79 & 44,497 & 2,862 & 27,812 & 1,758 & 17,083 & 1,034 & 10,046 & 717 & 6,964 \\
\hline 2003 & & 49 , & 3,034 & 30,846 & 1,864 & 947 & 1,096 & 11,142 & 760 & 7,724 \\
\hline 2004 & & 54, & 3,212 & 34,058 & 1,973 & 20,920 & 1,160 & 12,302 & 804 & 8,528 \\
\hline
\end{tabular}

(a) Certain waste forms and canister diameters are approximately equivalent in the amount of contained waste to other forms and diameters, i.e., a Calcine-Al matrix canister with a diameter of $40.6 \mathrm{~cm}$ is equivalent to a $50.8 \mathrm{~cm}$ dia borosilicate glass canister. 
One competitor for the canisters will be the pilot plant studies of permanent disposal methods. Plans call for two pilot plants to start receiving solidified waste fission product canisters in 1985 and be expanded to full-scale receiving rates in 1990. Two other pilot plants would start operation in 1987 with two additional plants coming on-line in 1989 and in 1991, respectively. $(14,15)$ These plants could use a relatively large quantity of canisters numbering in the thousands. The AGNS fuel reprocessing plant could possibily supply these pilot plants with the required canisters; this would depend on the canister parameters which are desired for testing. Other canisters could become available for pilot plant study from the solidification of defense wastes. Exxon Nuclear Co., Inc. has proposed a $1500 \mathrm{MTHM} / \mathrm{yr}$ (preliminary siting 0ak Ridge, Tennessee) ${ }^{(6)}$ which could begin operation in 1984 at the earliest with solidification of waste beginning in 1986 or 1987 . The first canisters would contain relatively "old" waste which could also be used in pilot plant studies. Thus, the first 2-yr-old waste would probably not be available until the 1990's. (a)

As a starting point for this economic feasibility study, it will be assumed that all the waste is solidified at $2 \mathrm{yr}$ of age and all the canisters are available to the Army for use in their steam plants. The heat generation rates as a function of time for the various canister sizes considered in Table 6.1 are presented in Figure 6.1. The decay is based on the information in Table 5.1 and Figure 5.2. Thus, at 2-yr waste age, these canisters have the centerline temperature limits stated in Figure 5.2 and have $200^{\circ} \mathrm{C}$ wall temperatures which approximates what might be experienced in steam boiler. Once again, certain canister sizes and wastes have almost the same heat loads and decay curves, therefore, where convenient, the curves have been combined.

The Army base concept is of separate boilers containing many canisters (from 10 to 40 canisters per boiler may be an appropriate range). Annual shipments of canisters would replace ones which would be thermally "cool".

(a) The "ground rules" for the basis of this present analysis were made during 1976; since that time, changes in these rules have taken place which significantly influence results and conclusions. For this reason, the last section, "12.0 - Update and Recommendations," addresses these changes and their impact. 
One method would be to have all the canisters in one boiler of approximately the same age. Then, a boiler could be unloaded, serviced if needed, and refilled with "fresh" canisters.

Assuming an overall thermal efficiency of $80 \%$, 6-MW would be needed for a 5-MW steam plant. Based on Figure 6.1 and Table 6.1, preliminary scenarios of steam plant requirements, waste forms, and canister sizes have been summarized in Table 6.2.

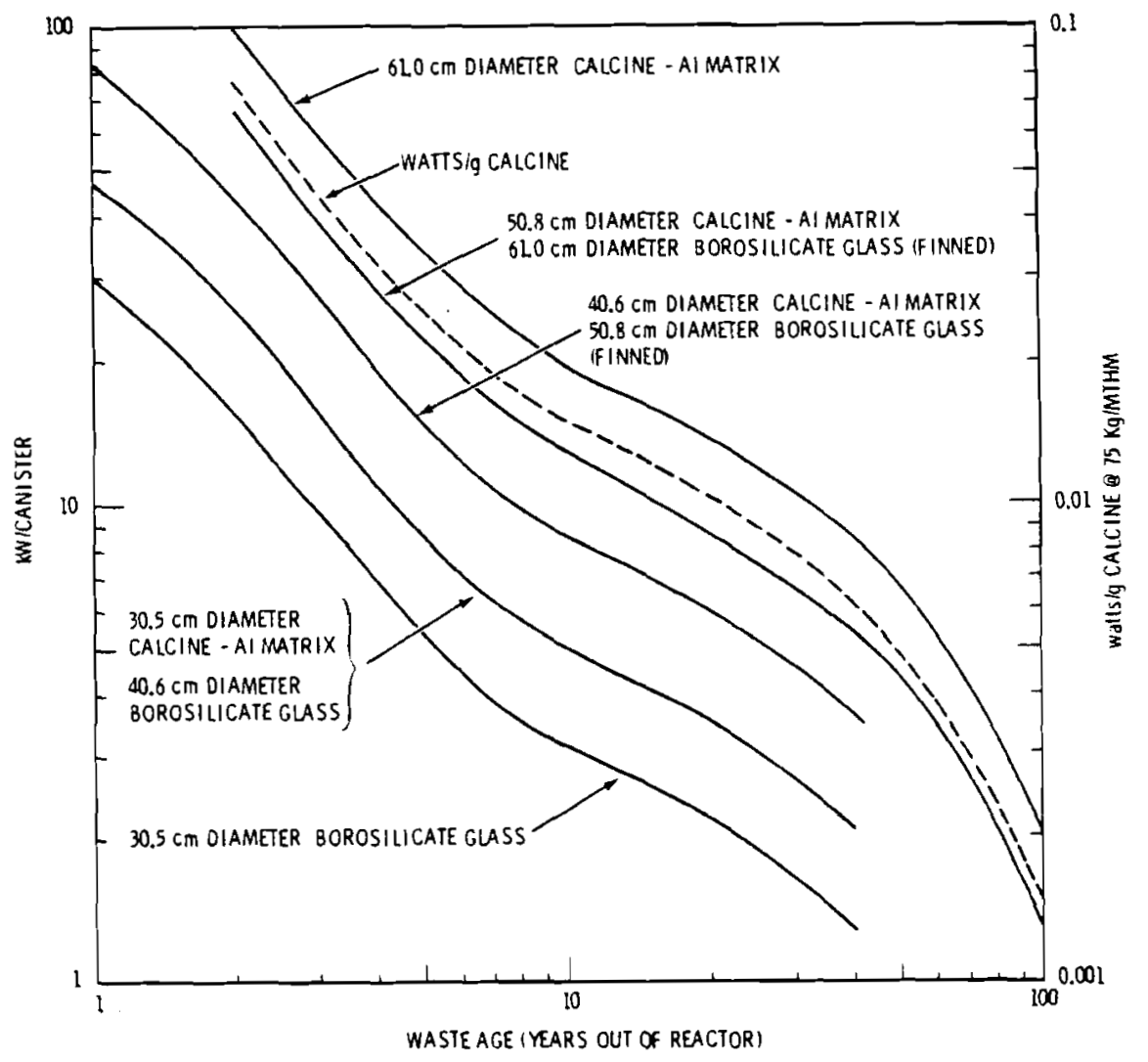

FIGURE 6.1. Canister Heat Generation Rate with Decay (Canister Length $=305 \mathrm{~cm}$ )

Table 6.2 presents some of the possibilities for supplying a 5-MW Army steam plant. The first four cases and the last two cases (calcine form) are attempts to meet or come close to salt mine criteria after Army use. The other cases are possibilities if an RSSF is built to allow final storage criteria levels to be met. The Army could aiso store in a water basin the 


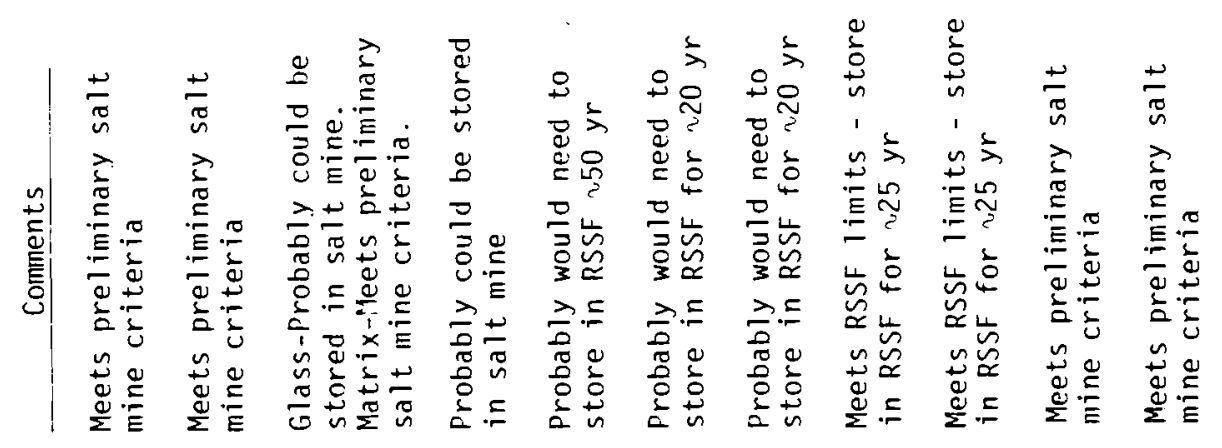

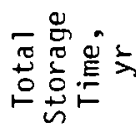

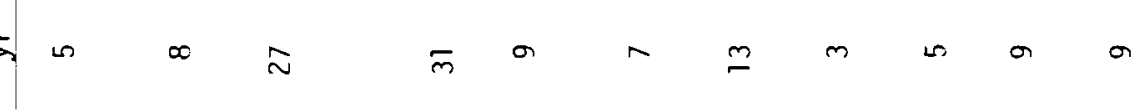

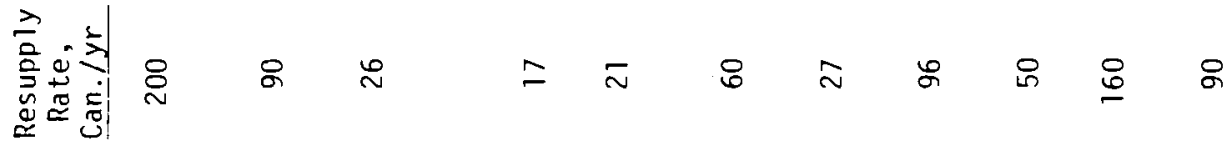

$\sum_{\substack{1 \\ i}}^{3}$

م

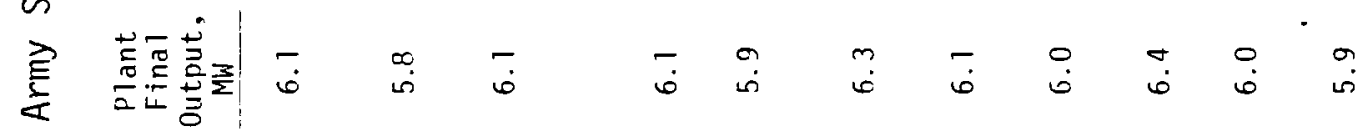

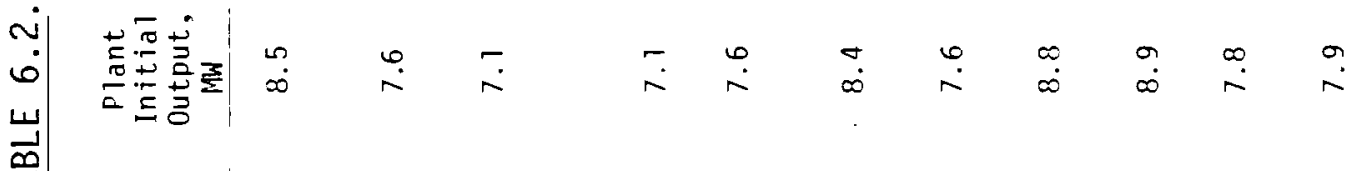

亲矛

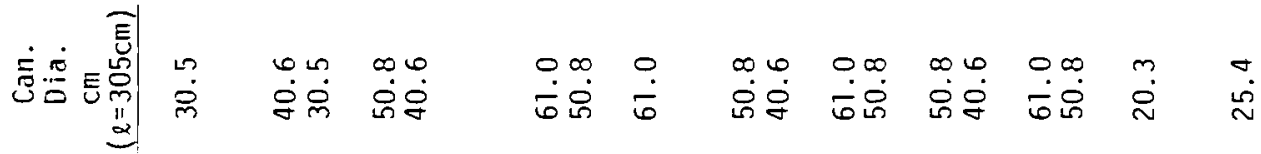

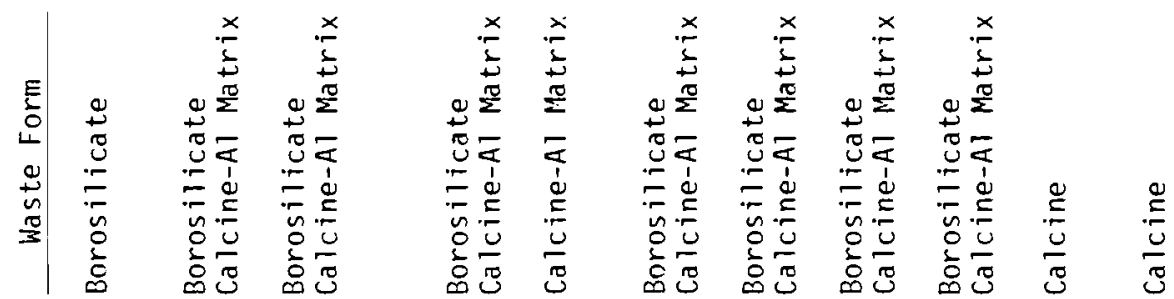


canisters not in use until the final storage heat load criteria are met. At this time the emphasis will be placed on schemes which enable the canisters to meet the preliminary salt mine criteria since these would probably have the lowest overall costs for the nuclear fuel cycle.

The particular canister diameter, waste form, and resupply schedule that are considered in detail are presented in Table 8.6 of Section 8.0, Steam Plant Design.

The section which follows immediately deals with steam plant licensing and safety which influences steam plant designs and costs. 
7.0 STEAM PLANT LICENSING AND SAFETY 


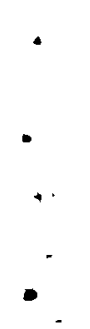




\subsection{STEAM PLANT LICENSING AND SAFETY}

The licensing/safety requirements for an Army steam plant fueled with solidified high-level waste canisters will have a significant impact on plant design and capital cost. The design objective is an economical plant that is safe and can be licensed by, or receive a license exemption from, NRC. This section describes the steam plant, then considers licensing aspects from three main sources: 1) direct reference to the Code of Federal Regulations, $(7,16)$ 2) analysis of past work on licensing requirements for the RSSF and 3) consideration of the requirements for spent fuel storage facilities. The impact of postulated licensing requirements on the steam plant design and costs completes this section.

\subsection{STEAM PLANT DESCRIPTION}

The design and size of the steam plant depends on the canister parameters including heat load, size, and waste form. A typical plant might have the following parameters:

- $5 \mathrm{MW}$ steam production $\left(177^{\circ} \mathrm{C}\right.$ saturated)

- resupply once per year

- $80 \%$ efficiency (7.6 MW initial - $5.8 \mathrm{MW}$ end of $\mathrm{yr}$ )

- waste form - borosilicate glass with internal fins

- waste age - between 2 and $10 \mathrm{yr}$

- canisters $-40.6 \mathrm{~cm}$ diameter, $305 \mathrm{~cm}$ long

- number of canisters - 720 (90 with 2-yr-old waste, 90 with 3-yr-old waste, etc.)

- contained radioactive material - $214 \mathrm{~kg}$ plutonium, $2 \times 10^{9} \mathrm{Ci}$ total, waste from reprocessing 3200 MTHM of spent fuel

- hottest canister - $25.3 \mathrm{~kW}, 5.4 \mathrm{MCi}$

- coolest canister - $5 \mathrm{~kW}, 1.4 \mathrm{MCi}$

- shielding material - water 


\subsection{CODE OF FEDERAL REGULATIONS}

The regulations pertaining to the use of solidified waste fission product canisters in a steam plant are not specifically mentioned in the Code of Federal Regulations. However, the receipt and storage of high-level waste from licensed activities (commercial fuel reprocessors) by ERDA is designated as requiring a specific license from NRC in Title 10 - Code of Federal Regulations - Part 70.11 (10 CFR 70.11); ${ }^{(7)}$ this also outlines the licensing to be for Special Nuclear Materials (10 CFR 70) since the waste contains uranium and plutonium. Exemptions may be issued to the Denartment of Defense by direction of the President (10 CFR 70.13).

Specific licenses in some cases will require environmental reports to be filed by applicants from which NRC will write environmental impact statements (10 CFR 51.5). Once again, storage of HLW (or a steam plant fueled by HLW) is not specifically mentioned in 10 CFR 51.5 However, it is stated that NRC will follow 40 CFR 1500.6. Council on Environmental Quality Guidelines which states, (16) ". . . if there is potential that the environment may be significantly affected, the statement is to be prepared." Since a 5-MW steam plant fueled with HLW would contain approximately $2 \times$ $10^{9} \mathrm{Ci}$ of radioactive material, an environmental report prepared by the applicant will likely be required unless an exception is acquired.

\subsection{RETRIEVABLE SURFACE STORAGE FACILITY (RSSF)}

Past work on the RSSF by the Atlantic Richfield Hanford Company (ARHCO) has provided information on potential requirements for licensing a steam plant. Joint meetings were held between ARHCO, NRC, and ERDA concerning the licensing of the RSSF, but final licensing criteria were not established due to the "mothballing" of the RSSF project. However, the results from preliminary discussions were provided by ARHCO Staff. There are dissimilarities between a 5-MW steam plant and an RSSF, for the steam plant: 1) the storage period will be much less than $100 \mathrm{yr}, 2)$ the amount of radioactive material will be less, and 3) the receiving rate of the canisters will be less. However, the undeniable similarities of handling and storing 
high-level waste canisters make consideration of the RSSF licensing aspects worthwhile. Requirements that were considered to be applicable to an RSSF were:

- Special Nuclear Materials Licensing (10 CFR 70) ${ }^{(7)}$

- Safety Analysis Report

- Environmental Report

- Structures must withstand natural phenomena

- Quality Assurance Program

- Physical Protection of Plants and Materials (10 CFR 73) $(7)$

- Onsite Meteorological Programs (Regulatory Guide 1.23) (17)

- Material Accountability and Controls

The latter requirement is more directed at fissionable mass. The highlevel waste that would be in a $5-M W$ steam plant would contain about $200 \mathrm{~kg}$ of plutorium, but it would be difficult to separate from the other waste and the canisters could not be put in a critical array. In this case a traceability program should be adequate.

\subsection{SPENT FUEL STORAGE FACILITIES}

Other types of facilities which, in some respects, are similar to possible army steam plants are spent fuel storage facilities. Similarities between these two types of facilities are the amount of stored radioactive material, the amount of heat generated, and the amount of water used for shielding and cooling. They are unlike steam plants in their concern for criticality in spent fuel storage.

Regulatory Guide 3.24, "Guidance on the License Application, Siting, Design and Plant Protection for An Independent Spent Fuel Storage Installation" (2) deals with the storage of 1000 MT or more of spent fuel producing in excess of $10^{9} \mathrm{Ci}$ and $2.9 \mathrm{MW}_{t}$. For this type of facility a summary of the requirements are:

- 10 CFR 70, "Special Nuclear Materials"(7)

- Federal Water Pollution Control Act amendments of 1972

- 10 CFR 51, "Licensing and Regulatory Policy and Procedures for Environmental Protection" 
- Regulatory Guide 4.2, "Preparation of Environmental Reports for Nuclear Power Plants" 17 is generally applicable as a guide for an environmental report. Specific subjects such as spent fuel transportation should be emphasized, but subjects relating only to nuclear power plants are not applicable.

An independent spent fuel storage installation (ISFSI) has its own support facilities and operates independently of a nuclear power reactor or fuel reprocessing plant. The general attitude of NRC concerning this type of facility is probably indicated in this statement from Regulatory Guide $3.24:^{(2)}$

"Because of the substantial quantity of contained radioactivity and the cooling requirements involved in an ISFSI, the review and evaluation of the engineered design and detailed safety analysis for the installation must be conducted before licensing. For this reason, a license application for an ISFSI should include a safety analysis report similar in scope and detail to the pertinent parts of a safety analysis report of a fuel reprocessing plant."

Thus, Regulatory Guide 3.26, "Standard Format and Content of Safety Analysis Reports for Fuel Reprocessing Plants" ${ }^{(19)}$ could be used as a guide. Other subjects which receive consideration in the Regulatory Guide 3.24 are:

- Site Selection - based on environmental effects from normal operation, and information on meteorology, geology, seismology, and hydrology

- Design - based on maintaining integrity of fuel cladding as primary barrier

- for pool integrity impervious soil or a secondary water containment envelope will be needed

- heat dissipation will need a highly reliable water supply and an emergency power supply

- ventilation will be needed for worker and environmental protection according to 10 CFR Part $20(7)$ 
- radioactive liquid effluents should not be discharged waste treatment will provide suitable product for disposal

- credible accidents to be included in the design are: criticality, loss of shielding water, dropping heavy loads on fuel, massive rupture of fuel elements by missiles, and complete loss of cooling water

- storage racks should be designed within seismic and missile criteria

- Physical Protection - a protection system according to 10 CFR 73 will be required.

Further details of what an applicant should provide for the license application are listed in Regulatory Guide 3.24. Also, for design it is recommended that ANSI standard N305 "Design Objectives for Highly Radioactive Solid Material Handling and Storage Facilities in a Reprocessing Plant" be used. For more specific information on the above subjects the reader is referred to the Regulatory Guide itself.

\subsection{ARMY STEAM PLANT}

The most similar facilities or devices to an Army steam plant fueled with waste fission product canisters which have been considered by NRC are the RSSF and spent fuel storage facilities. The major similarities are:

- large quantities of contained radioactive material $\left(>10^{9} \mathrm{Ci}\right)$

- large quantity of heat generation

- water shielding and cooling (RSSF water basin concept).

Therefore, the licensing requirements and procedures for an Army plant will most likely follow those presented in the preceding two sections (except for criticality) unless the Army receives an exception by Presidential direction, and the design of a steam plant should follow the existing information on RSSF facilities and spent fuel storage facilities. Some characteristics specific to a steam plant could reduce the requirements from those of an RSSF or spent fuel storage facility, such as: 1) 10-yr storage for facility (RSSF storage is $100 \mathrm{yr}$ ), 2) canister delivery and 
shipping rate only about 100/yr, and 3) no criticality danger. Examples of requirements which probably cannot be reduced are those for stainless steel basin liners, the double barrier concept, and hardening of facilities against earthquakes and missiles.

The characteristics and quality of the canisters will be important to the steam plant design. This will influence the capabilities required at the steam plant for unloading, decontamination, and canister repackaging. At the RSSF a hot cell was provided for canister handling including cooling of received canisters, decontamination, and overpack addition. If a hot cell were required at a steam plant, however, the capital cost could be significantly higher. For the designs considered here it will be assumed a hot cell for canister receiving will not be required for licensing a steam plant. This is based on the following assumptions:

- In the presently forecast time frame for steam plants going on-line (1980's), a canister will be developed which will be compatible with use in a steam plant. Thus, canisters developing leaks will be an infrequent occurrence. This would be assisted by a relatively short storage time, i.e., $10 \mathrm{yr}$ compared to $30 \mathrm{yr}$ or more.

- Canisters or casks received in a contaminated condition will be an infrequent occurrence.

- Upon receipt, the interior of the cask will be filled with water which is at a temperature high enough to reduce thermal stress in the canisters. The water will be recirculated, cooled, and monitored. This serves the purpose of cooling the canisters, inspecting the canisters for contamination (gas sampling may not be sensitive enough) and, if contamination is present, will minimize the water requiring treatment. If contamination is present, the cask will be resealed and returned to the fue 1 reprocessor or waste disposal site for decontamination/repackaging.

- The canisters will be used in modular type boilers. If a leaking canister is detected (assumed to be an infrequent occurrence) that canister will be placed in a special cask for a single canister, the exterior of the cask will be decontaminated, and the cask will be shipped to a facility which can repackage or dispose of the leaking canister. 
It should be recognized that these assumptions depend on testing and qualification of the canister design. It may be necessary to have a hot cell facility in the first steam plant until the reliability of the canisters is shown. This will depend on the percent completion of the canister qualification program versus the forecast of initial plant start-up. The time of canister use in a steam plant will also influence the canister design. If canisters are used for 20 or more years rather than for only $10 \mathrm{yr}$, it will be more difficult to demonstrate that a hot cell receiving facility is not required and the canister costs could be increased significantly (special materials, thicker walls, etc.). Another factor is the potential NRC requirement to ship the canisters dry. Also some sort of repackaging capability could be required even if the canister was highly qualified. A hot cell might be the most convenient method to meet these potential requirements.

Something else which may influence the overall cost of a steam plant is the potential funding needed for licensing. From the preceding analysis licensing as a special nuclear material and the preparation of an environmental impact statement will be required unless an exemption is granted. Significant money can be spent on environmental reports, site evaluations, safety analysis reports, etc. It may be feasible to have some of these reports written based on a generic plant so the costs may be distributed over more than one steam plant. However, costs for site selection will apply to each site. For now it will be assumed all licensing costs are distributed over many plants and these costs are minor compared to the facility capital cost.

The next section discusses the characteristics of the type of steam plants that will be considered further. Heat transfer analyses related to certain waste form, canister sizes, and boiler concepts will be presented. Two boiler concepts are considered in detail along with steam plant operation. 


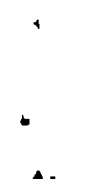

4

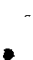




\subsection{STEAM PLANT DESIGN}




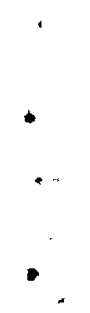




\subsection{STEAM PLANT DESIGN}

A steam plant fueled with high level waste canisters has four main components: 1) boilers containing the canisters and working fluid, 2) radiation shielding, 3) structural support, and 4) canister receiving! handling, and many sub-components such as piping, water treatment system, and radioactive waste handling systems. In the following sections the major emphasis is placed on boiler design versus canister parameters, and on the overall size of the plant.

Two main concepts have been developed for steam plant design and each concept has its advantages and disadvantages. Before the best concept can be selected, they must both be well defined and the economics of each must be investigated.

\subsection{BOILER CONCEPTS}

All boiler concepts for this application have two characteristics: 1) an outer shell or wall to contain the boiling working fluid, and 2) boiler tubes providing a barrier between the high-level waste and the working fluid. Only multiple canister boilers will be considered here since single canister boilers would require more materials resulting in increased capital costs. Depending on the boiler concept, the boiler tube is a steel pipe in which the canister is placed or it is the bare canister wa11. These boiler tubes are formed into an array or bundle, similar to nuclear reactor fuel elements except with much larger dimensions. In all cases, the working fluid is water.

Although the overall boiler geometry can be rectangular or cylindrical, cylindrical geometry affords more strength for the pressure vessels. The optimum cylindrical design is one that accommodates the largest number of canisters. These canisters can be arranged in several arrays such as the 19-canister and 37-canister arrays shown in Figures 8.1 and 8.2, respectively. Variations from these number of canisters would increase the void space between canisters which in turn would increase overall plant size and costs. 
BOILER DIAMETER $=5.66 d+2.66 x$

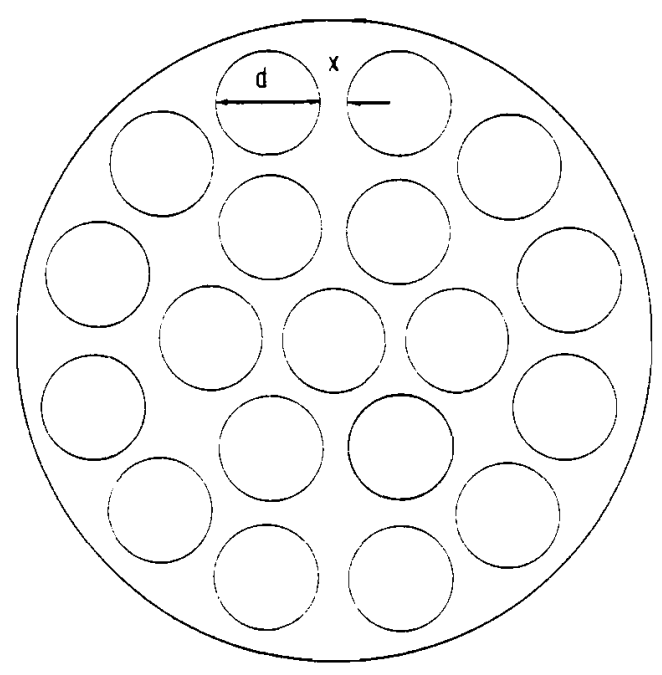

FIGURE 8.1. 19 Canister Array

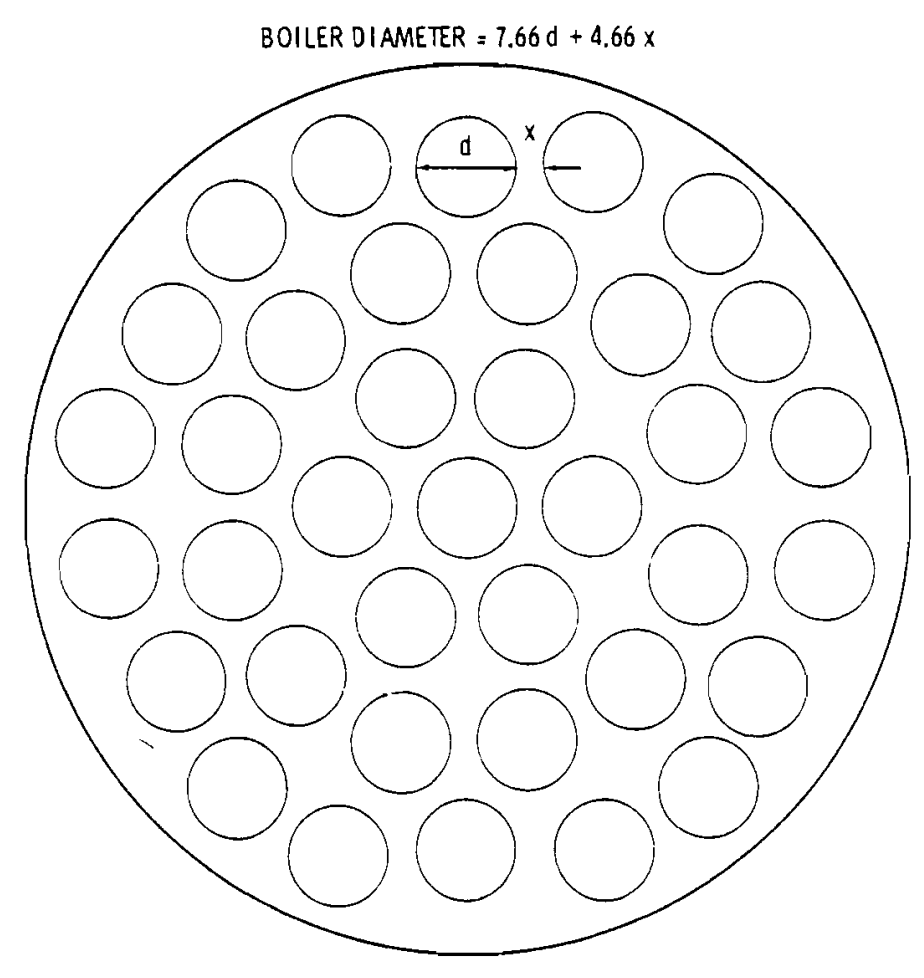

FIGURE 8.2. 37 Canister Array 
Although the number of canisters containing waste of a particular age and diameter for a specific canister refueling scheme (see Table 6.2) may not equal 19 or 37 , there would be no problem in having canisters of different ages in the same boiler. Figures 8.1 and 8.2 also give formulas for calculating overall boiler diameter as a function of boiler tube (or canister) diameter and minimum spacing between tubes.

Two main boiler concepts will be used for steam plant design. Concept 1 is a boiler with the canisters inserted in open tubes and the working fluid is used directly in the steam system (Figure 8.3). Concept 2 employs a large pressure vessel where canisters are in direct contact with the working fluid; the working fluid passes through a second heat exchanger to produce steam (Figure 8.4).

Concept 1 will use the 37-canister array. Concept 2 will use the 19-canister array, but the canisters will be double stacked because the major cost for the pressure vessel will be for the vessel head since the side walls will be reinforced with concrete. Double stack storage has been used in nuclear fuel element storage and was considered feasible in the RSSF water basin storage concept; gates are employed in the storage racks to allow access to the lower racks.

Any concept to produce steam from HLW canisters must include a pressure vessel shielded for radiation. Concept 1 originated with the work of Safonov ${ }^{(3)}$ who assumed that the boiler and the water shielding tank could be made from carbon steel; no material was specified for the basin liner. For steam plant licensing (see Section 7.0), stainless steel may be required as a material for most surfaces that could become contaminated with radioactive material. If this were true, the boilers and water shield tanks would have to be made from stainless steel and a stainless basin liner would be required. Due to the cost of stainless steel, Concept 2 was developed to reduce the amount of stainless steel required in the steam plant.

An important feature for licensing is the double barrier principle. In Concept 1 the first barrier is the canister wall and the second is the 


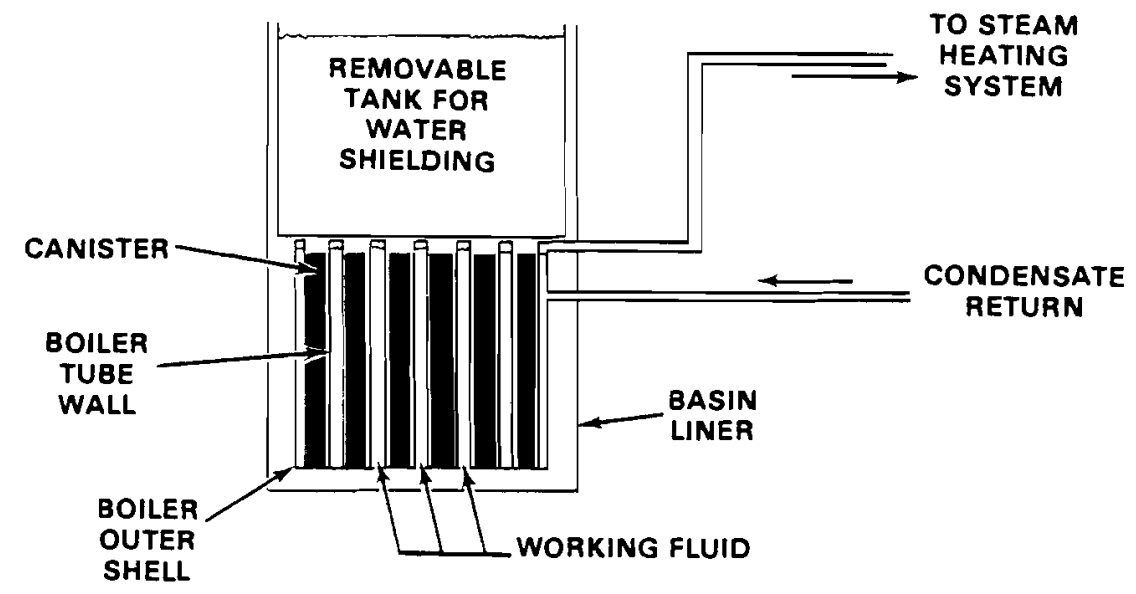

FIGURE 8.3. Schematic of Concept 1

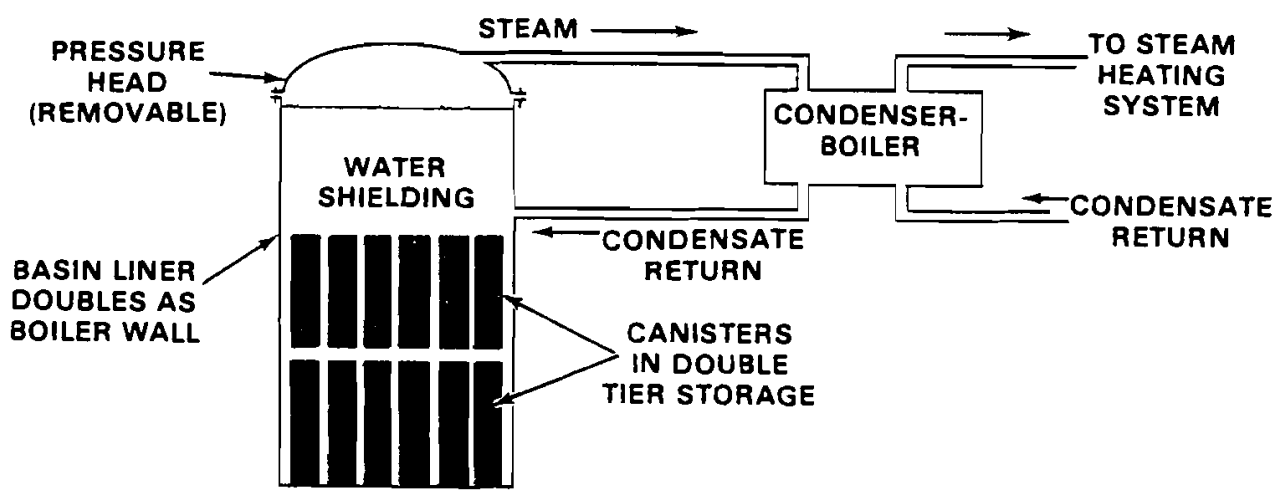

FIGURE 8.4. Schematic of Concept 2

boiler tube; the working fluid is used directly in the steam heating system. In Concept 2 the first barrier is the canister wall and the second is the heat exchanger tubes. Concept 2 has several advantages over Concept 1 with respect to the double barrier principle:

- The surface area of the second barrier in Concept 2 (heat exchanger tubes) is much smaller than Concept l's second barrier (boiler tube), thus the costs of materials for providing a second barrier should be much less in Concept 2 than in Concept 1. 
- The first barrier in Concept 2 would be more easily and effectively monitored for failure than the first barrier in concept 1 by simply monitoring the working fluid (in both concepts the canister wall is the first barrier). In concept 1 monitoring the air gap between the canister wall and boiler tube would be difficult and expensive. For this reason, in subsequent analyses it will be assumed that a canister overpack exists in Concept 1. This will slightly increase boiler size and capital costs but makes concept 1 more acceptable from a licensing standpoint.

Concept 1 could also employ a secondary heat transfer loop, but the boilers and boiler tubes would not be required to meet the double barrier principle. Another factor is if contamination was released in one of the basins, the larger surface area of Concept 1 could involve more extensive decontamination operations.

A. though Concept 2 apparently has advantages over Concept 1 , the decision of which concept is best can be assisted by looking at economics. Therefore, cost estimates will be developed for each concept. Also, since it is likely, but not definite, that stainless steel surfaces will be required for 1 icensing Concept 1 , costs will also be presented for carbon steel shielding tanks and boilers. The basin liner will be considered as stainless steel in all cases since both the RSSF-Water Basin concept and Spent Fuel Storage Facilities have them.

\subsection{BOILER HEAT TRANSFER}

Boiler heat transfer takes place between the boiler tube and the boiling working fluid; it is a function of the tube bundle geometry, boiler tube heat flux, and method of fluid circulation. The temperature difference between the working fluid and the boiler tube affects the centerline temperature of the canister. The goal is to have good heat transfer (low temperature difference) in the tube bundle to allow canisters to have relatively high heat loads and large diameters without exceeding their centerline temperature limits. 
There are three methods of working fluid circulation in a tube bundle: forced convection by pumping, natural circulation thermosiphon, and pool boiling. In many boilers the heat flux is large enough that it will cause an appreciable temperature drop between the heater wall and working fluid due to formation of a stagnant vapor layer unless it is forced or naturally circulated. However, for the case of using HLW canisters to boil water, the heat flux is relatively low and pool boiling may be satisfactory. The advantages of using pool boiling are the capital savings in not requiring pumps or thermosiphon tubes. Care must be given to the spacing of the canisters in the boiler. If they are too close, the vapor fraction may become large enough between the canisters to cause hot spots in the canisters.

Most work on pool boiling has been for horizontal surfaces or short ( 1 ft long) vertical surfaces, but enough information is available to analyze a waste canister boiler. Various steam plant concepts were considered before Concepts 1 and 2 were specified; the potential temperature range was identified as 212 to $550^{\circ} \mathrm{F}$. A discussion of the whole range is included here for completeness. Table 8.1 presents the properties of saturated steam at these temperatures. The temperatures of the saturated steam that would be at the bottom of the canister walls due to the $23 \mathrm{ft}$ liquid head ( $10 \mathrm{psi}$ ) were also considered. This has a significant influence only in the $212^{\circ} \mathrm{F}$ range and results in a maximum temperature of $240^{\circ} \mathrm{F}$.

TABLE 8.1. Physical Properties and Critical Heat Flux for Boiling water

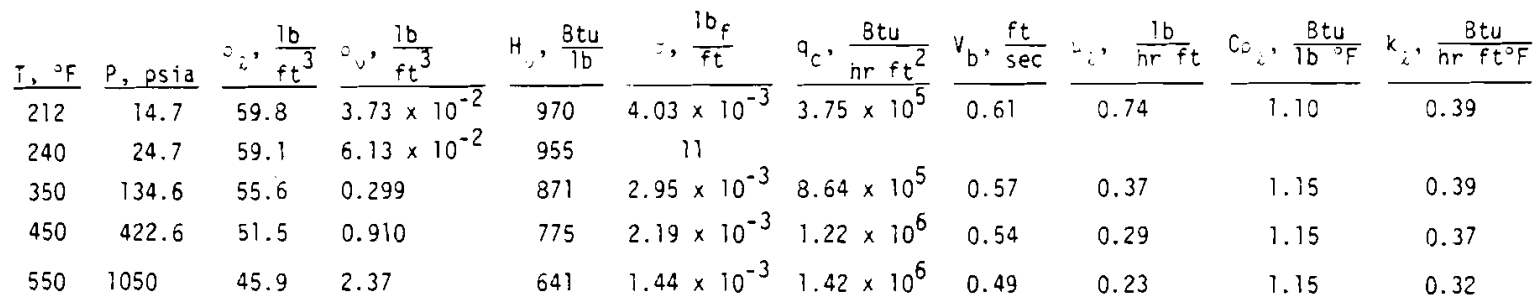

Table 8.1 also tabulates the critical heat fluxes calculated at various temperatures by the Kutateladze's ${ }^{(21)}$ method (the heat transfer correlations and nomenclature used here are included at the end of this section). Critical heat flux is the flux where the transition between nucleate and film boiling occurs. 
Any heat flux above these values will cause a drop in heat transfer coefficient and an increase in the temperature difference between the working fluid and boiler tube (a situation to be avoided). Table 8.2 presents parameters for various waste forms and canister sizes including heat flux. All the canister heat fluxes are about a factor of 100 below the critical heat fluxes. Kutateladze's correlation gives $25 \%$ higher results than those for vertical walls. (21) However, the critical heat fluxes are still much higher than the canister wall fluxes.

TABLE 8.2. Boiler Heat Transfer

\begin{tabular}{|c|c|c|c|c|c|c|c|c|c|c|c|c|}
\hline \multirow[b]{2}{*}{ Waste Form } & \multirow[b]{2}{*}{$\begin{array}{r}\text { Dia, } \\
\text { in }(\mathrm{cm}) \\
\end{array}$} & \multirow[b]{2}{*}{$\begin{array}{l}\text { Can. } \\
\text { Heat } \\
\text { Load, } \\
\text { kk' } \\
\end{array}$} & \multirow[b]{2}{*}{ c. $\frac{\text { etu }}{n r f t^{2}}$} & \multirow{2}{*}{\multicolumn{4}{|c|}{$\begin{array}{c}\text { Minimum Distance } \\
\text { Between Boiler Tubes } \\
\text { b, in. }\end{array}$}} & \multicolumn{5}{|c|}{$\begin{array}{l}\text { Temperature Difference } \\
\text { Between Working } \\
\text { Fluid and Boiler Tube }\end{array}$} \\
\hline & & & & & & & & $\begin{array}{l}\mathrm{T},{ }^{\circ} \mathrm{F} \\
212^{\circ} \mathrm{F} \\
\end{array}$ & $350^{\circ} \mathrm{F}$ & $\begin{array}{l}\text { senow: } \\
450^{\circ} \mathrm{F} \\
\end{array}$ & $550^{\circ} \mathrm{F}$ & 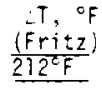 \\
\hline \multirow{4}{*}{ Borosificate alass } & $12(30.5)$ & 15.0 & 1920 & 10.4 & 1.6 & 0.6 & 0.3 & 12.2 & 4.1 & 2.6 & 2.4 & 7.9 \\
\hline & $16(40.6)$ & 25.3 & 2290 & 12.5 & 1.9 & 0.7 & 0. 4 & 13.0 & 4.4 & 2.8 & 2.6 & 8.3 \\
\hline & $20(50.8)$ & $\angle 4.5$ & 3220 & 17.5 & 2.6 & 1.0 & 0.5 & 14.5 & 4.9 & 3.7 & 2.9 & 9.0 \\
\hline & $24(67.0)$ & 66.5 & 4010 & 21.8 & 3.3 & 1.3 & 0.6 & 15.6 & 5.3 & 3.3 & 3.1 & 9.5 \\
\hline \multirow[t]{4}{*}{ Calcine-Al Matrix } & $12(20.5)$ & 25.3 & 3051 & 15.6 & 2.5 & 1.0 & 0.5 & $14 . \hat{3}$ & 4.8 & 3.0 & 2.8 & 8.9 \\
\hline & $76(40.6)$ & 44.5 & 4030 & 21.9 & 3.3 & 1.3 & 0.6 & 15.6 & 5.3 & 3.3 & 3.1 & 9.6 \\
\hline & $20(50.8)$ & 60.5 & 4820 & 26.2 & 3.9 & 1.5 & 0.8 & $16 . \epsilon$ & 5.6 & 3.5 & 3.3 & 10.0 \\
\hline & $24(61.0)$ & 100.7 & 6080 & 32.1 & 4.9 & 1.9 & 1.0 & 17.9 & 6.0 & 3.8 & 3.4 & 10.6 \\
\hline \multirow[t]{4}{*}{ Calcine } & $E(15.2)$ & 5.7 & 1380 & 7.5 & 1.1 & 0.4 & 0.2 & 11.0 & 3.7 & 2.3 & 2.2 & 7.3 \\
\hline & $8(20.3)$ & 10.7 & 1830 & 10.0 & $1 . \tilde{5}$ & 0.5 & 0.3 & 12.0 & 4.0 & 2.6 & 2.4 & 7.8 \\
\hline & $10(25.4)$ & 15.7 & 2270 & 12.3 & 1.8 & 0.7 & 0.4 & 12.9 & 4.3 & 2.7 & 2.6 & 8.3 \\
\hline & 12 (30.5) & $22 . \epsilon$ & 2730 & 14.8 & 2.2 & 0.9 & 0.4 & 13.7 & 4.6 & 2.9 & 2.7 & 8.7 \\
\hline
\end{tabular}

To give an indication of the minimum al lowable space between canisters, a shell balance can be used to derive a relationship between void fraction, distance up the canister, distance between canisters, etc. This derivation for an incremental shell between two boiler tube (or canister) walls is presented below:

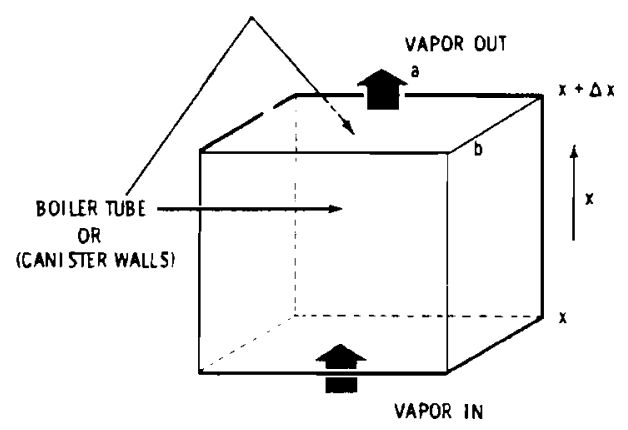


Assuming constant velocity of vapor only in the $x$ direction, constant temperature in the $x$ direction, and negligible liquid flow, a vapor balance is:

$$
\begin{aligned}
& \text { vapor in + vapor generated = vapor out } \\
& V \varepsilon_{x} a b+\frac{2 q a \Delta x}{H_{\nu} \rho_{\nu}}=V \varepsilon_{x}+\Delta x
\end{aligned}
$$

where

$$
\begin{aligned}
V & =\text { vapor (or bubble) velocity, ft/hr } \\
\varepsilon & =\text { void fraction, dimensionless } \\
a & =\text { incremental shell width, ft } \\
b & =\text { distance between boiler tubes, ft } \\
\Delta x & =\text { incremental shell length, ft } \\
H_{v} & =\text { heat of vaporization, Btu/lb } \\
\rho_{\nu} & =\text { vapor density, } 1 \mathrm{~b} / \mathrm{ft}^{3} \\
q & =\text { heat flux, BTU/hr }-\mathrm{ft}^{2}
\end{aligned}
$$

Taking the limit as $\Delta x \rightarrow 0$

$v a b d \varepsilon=\frac{2 q a}{H_{\nu} \rho_{\nu}} d x$

integrating from $d \varepsilon=\varepsilon$ to 0 and $d x=L$ to 0 and rearranging

$$
\varepsilon=\frac{2 q}{V b H_{v} \rho_{v}}
$$

where $L=$ total height of boiler tubes, $\mathrm{ft}$; rearranging again

$$
b=\frac{2 g L}{V H_{\nu} \rho_{\nu} \varepsilon}
$$

For a specified void fraction $\varepsilon$ at the top of the boiler tubes (L), a minimum distance between boiler tubes (b) can now be estimated. This situation is somewhat idealized since the formation of vapor can cause flow in directions other than $x$ and the temperature in the $x$-direction is not constant. However, proper choice of constants should allow the calculation of conservative values of $b$ versus $\varepsilon$ since the heat flux is relatively small. If $\varepsilon$ becomes too large, the vapor will interfere with the boiling heat transfer, a situation which has been termed vapor binding. Using the results of woods, et a1., (p. 398, Reference 22), a representative maximum void fraction for vapor 
binding effects appear to be 0.5 . Using $\varepsilon=0.5$ at the top of the canister $(L=9 \mathrm{ft})$ the minimum distance between bare canisters (b) was calculated for a number of diameters and waste forms containing 2-yr-old waste (borosilicate, Calcine-Al matrix, and calcine). The working fluid temperatures were taken as $212,350,450$, and $550^{\circ} \mathrm{F}$. Vapor velocities were obtained from the observations of Peebles and Garber of velocity of bubbles in a gravitational field (p. 19, Reference 21). The results are given in Table 8.2. This indicates forced convection or thermosiphon operation may be needed only if the working fluid temperature is $212^{\circ} \mathrm{F}$. This is due to the low density of saturated vapor at $212^{\circ} \mathrm{F}$. If the temperature and density of saturated vapor at the bottom of the boiler $\left(240^{\circ} \mathrm{F}\right)$ are used, the minimum distances between boiler tubes would be halved. The use of $212^{\circ} \mathrm{F}$ properties is more conservative. Since $212^{\circ} \mathrm{F}$ is 1 ower than $350^{\circ} \mathrm{F}$, vapor binding at $212^{\circ} \mathrm{F}$ may not be a problem for canister temperature limits since the vapor will still remove heat, but less efficiently than boiling water. It should be noted that as the boiling working fluid's temperature (and pressure) is increased, the minimum gap between canisters decreases due to the increased vapor density.

The above discussion indicates operating temperatures greater than $350^{\circ} \mathrm{F}$ will not need forced convection or thermosiphon operation. However, every boiler will be refueled by lowering the operating temperature below $212^{\circ} \mathrm{F}$ and the operating pressure to atmospheric. During these periods, a recirculating pump will be needed to remove hot water from the boiler to a cooler. The shutdown operation could first begin by lowering the system temperature instead of pressure to eliminate flashing of cooling water. In any event, each concept will require a cooling system involving pumps; these pumps could also be used to circulate liquid during normal operation if it is required. An advantage of higher operating temperatures is that pumps would not be needed during normal operation (reducing operating costs).

The difference in temperature between the working fluid and boiler tube (or canister wall) can be estimated by use of the Rohsenow correlation (21) of nucleate pool boiling data. This is for horizontal heating surfaces. In the vertical situation, the stirring action of the rising bubbies can lower 
the temperature difference unless, as mentioned previously, the void fraction becomes too high. The results for the temperature range of interest are pre-. sented in Table 8.2. The maximum $\Delta \mathrm{T}$, about $20^{\circ} \mathrm{F}$, is for $212^{\circ} \mathrm{F}$ boiling liquid. For natural convection boiling at atmospheric pressure in vertical tubes, Fritz ${ }^{(23,24)}$ has developed a correlation based on data from different investigators. Tube lengths were between $11 / 2$ to $61 / 2 \mathrm{ft}$ and tube diameters were between 1.1 to $2.3 \mathrm{in}$. The $\Delta T \mathrm{~s}$ from this correlation are also presented in Table 8.2; these are slightly less than those predicted by the Rohsenow correlation.

Apparently the temperature difference between the working fluid and the boiler tube wall will have minor impact on increasing the canister centerline temperatures as long as the boiler is designed to eliminate vapor binding problems. Thus, this particular temperature difference is ignored in the subsequent section on canister temperature distributions.

The correlations used in the preceding analysis are:

Kutateladze Correlation: ${ }^{(21)}$ Critical Heat Flux for Pool Boiling

$$
q_{c}=\left(0.14 \rho_{\nu}\right)^{0.5} H_{v}\left(\sigma g_{c}\left(\rho_{\ell}-\rho_{v}\right) g\right)^{0.25}
$$

Peebles and Garber: ${ }^{(21)}$ Bubble Velocity in a Gravitational Field

$$
v_{b}=1.18\left[\frac{\sigma g_{c} g\left(\rho_{l}-\rho_{\nu}\right)}{\rho_{\ell}^{2}}\right]^{0.25}
$$

Rohsenow Correlation: ${ }^{(21)}$ Nucleate Pool Boiling Data

$$
\left.\frac{C_{\ell}\left(T_{W}-T_{\ell}\right)}{H_{v}}=0.013\left[\frac{q}{\mu_{\ell} H_{v}}\left(\frac{g c_{\sigma}}{g\left(\rho_{\ell}\right.} \rho_{v}\right)\right)^{0.5}\right]^{0.33}\left(\frac{c_{\ell} \mu_{\ell}}{k_{\ell}}\right)^{1.7}
$$

Fritz Correlation: $(23,24)$ water Boiling in Tubes at Atmospheric Pressure

$$
\begin{aligned}
h & =0.83(q)^{0.75} \\
T_{W}-T_{\ell} & =q / h \\
T_{W}-T_{\ell} & =1.2(q)^{0.25}
\end{aligned}
$$


Description of Variables Used in Correlations:

$$
\begin{aligned}
& q_{c}=\text { critical heat flux, Btu/hr-ft }{ }^{2} \\
& \rho_{v}=\text { vapor density, } 1 \mathrm{~b} / \mathrm{ft}^{3} \\
& f_{\ell}=1 \text { iquid density, } 1 \mathrm{~b} / \mathrm{ft}^{3} \\
& g=\text { acceleration of gravity, } 32.2 \mathrm{ft} / \mathrm{sec}^{2} \\
& g_{c}=\text { conversion ratio, } 32.21 \mathrm{~b}_{\mathrm{m}}-\mathrm{ft} / 1 \mathrm{~b}_{\mathrm{f}}-\mathrm{sec}^{2} \\
& H_{v}=\text { heat of vaporization, Btu/lb } \\
& \sigma=\text { surface tension, } 7 \mathrm{~b} / \mathrm{ft} \\
& v_{b}=\text { bubble velocity, } \mathrm{ft} / \mathrm{sec} \\
& C_{\ell}=\text { heat capacity of liquid, Btu/lb- }{ }^{C} F \\
& T_{W}=\text { wall temperature, }{ }^{\circ} \mathrm{F} \\
& T_{\ell}=\text { temperature of boiling liquid, }{ }^{\circ} \mathrm{F} \\
& \mu_{\ell}=1 \text { iquid viscosity, } 1 \mathrm{~b} / \mathrm{hr}-\mathrm{ft} \\
& k_{\hat{\ell}}=1 \text { iquid thermal conductivity, Btu/hr-ft- }{ }^{\circ} \mathrm{F} \\
& q=\text { heat flux, Btu/hr }-\mathrm{ft}^{2} \\
& h=\text { heat transfer coefficient, Btu/hr-ft }{ }^{2}-{ }^{\circ} \mathrm{F}
\end{aligned}
$$

\subsection{CANISTER TEMPERATURE DISTRIBUTIONS}

The canister sizes are limited by the maximum allowable centerline temperatures of the various waste forms. These centerline temperatures depend on the boiler geometry and working fluid temperature. A spectrum of calculations covering potential boiler geometries and boiler concepts were made for calcine with fins, borosilicate glass, borosilicate glass with fins, and calcine-aluminum matrix. The geometries considered were:

- boiler tube - overpack - canister wall,

- boiler tube - canister wall, and

- bare canister wall.

In some cases, waste fresher than 2-yr-old, emissivities of surfaces equal to 0.9 , and helium in the gap between the canister wall and overpack were considered. Wastes fresher than 2 yr increased the canister centerline 
temperature above the maximum in all cases studied. Helium addition was found to have insignificant influence, but increasing the emissivity has advantages in several cases. The results and discussion of all the calculations are presented in Appendix B; Table 8.3 presents the limiting cases for each geometry, waste form, and canister diameter for 2-yr-old waste. For some waste forms in the boiler tube and canister geometries the results were interpolated. Also included in Table 8.3 are the dimensions for both 19-and 37-canister boilers (based on a gap of 3 in. between boiler tubes which is greater than the minimum gaps shown in Table 8.2, Section 8.2).

\section{TABLE 8.3. Canister Temperatures}

\begin{tabular}{|c|c|c|c|c|c|c|c|c|c|c|c|c|}
\hline \multicolumn{3}{|c|}{ Concept } & \multirow[b]{2}{*}{ Waste Form } & \multirow[b]{2}{*}{$\begin{array}{l}\text { Number } \\
\text { of Fins }\end{array}$} & \multirow{2}{*}{$\begin{array}{c}\text { Canister } \\
\text { I.D. } \\
\text { in. (cm) } \\
\end{array}$} & \multirow[b]{2}{*}{$\begin{array}{l}\text { Boifer Tube } \\
0.0 ., \text { in. }\end{array}$} & \multirow[b]{2}{*}{$\begin{array}{l}\text { Working } \\
\text { Fluid, }\end{array}$} & \multirow[b]{2}{*}{$\begin{array}{c}\text { Canister } \\
\text { Na11 T, }{ }^{\circ} \mathrm{F} \\
\end{array}$} & \multirow[b]{2}{*}{$\begin{array}{c}\text { Canister } \\
\mathrm{T}_{\mathrm{G}}, \mathrm{F} \\
\end{array}$} & \multirow[b]{2}{*}{$\therefore$ in. } & \multirow{2}{*}{\multicolumn{2}{|c|}{ Boiler Diameter, ft }} \\
\hline $\begin{array}{l}\text { Boiler } \\
\text { Tube }\end{array}$ & Overpack & $\begin{array}{c}\text { Canister } \\
\text { Wall } \\
\end{array}$ & & & & & & & & & & \\
\hline$x$ & $x$ & $x$ & Borosilicate ${ }^{(a)}$ & 0 & $12(30.5)$ & 16 & $350-550$ & $790-880$ & $13 \overline{44}-1403$ & 3 & 8.2 & 11.4 \\
\hline \multirow[t]{2}{*}{$x$} & & $x$ & & 0 & $14(35.6)$ & 17.25 & $350-450$ & - & probably OK & 3 & 8.8 & 12.2 \\
\hline & & $x$ & & 0 & $16(40.6)$ & 16 & $350-450$ & $357-556$ & $1471-1455$ & 3 & 8.2 & 11.4 \\
\hline$x$ & $x$ & $x$ & & 8 & $16(40.6)$ & 20 & $350-550$ & $880-0 K$ & $1383-0 K$ & 3 & 10.1 & 13.9 \\
\hline \multirow[t]{2}{*}{$x$} & & $x$ & & 8 & $18(45.7)$ & 21.25 & $250-450$ & -- & probably OK & 3 & 10.7 & 14.7 \\
\hline & & $x$ & & 8 & $20(50.8)$ & 20 & 350 & 399 & 1444 & 3 & 10.1 & 13.9 \\
\hline$x$ & $x$ & $x$ & Calcine ${ }^{(a)}$ & 3 & $8(20.3)$ & 12 & $350-450$ & $850-390$ & $: 454-1476$ & 3 & 6.3 & 3.8 \\
\hline$x$ & & $x$ & & 8 & $10(25.4)$ & 13.25 & $350-450$ & - & probably OK & & 6.9 & 9.6 \\
\hline$x$ & $x$ & s & $\begin{array}{l}\text { Calcine }-4 i^{(3)} \\
\text { Matrix }\end{array}$ & 0 & $2^{(c)}(30.5)$ & 16 & 212 & 1172 & 1208 & 3 & 3.2 & 17.4 \\
\hline$x$ & $x$ & $x$ & & 0 & $6^{(d)}(40 . \overline{6})$ & 20 & 550 & $i 079$ & 1145 & 3 & 10.1 & 13.9 \\
\hline \multirow[t]{2}{*}{$x$} & & $x$ & & 0 & $16(40.6)$ & 18.5 & $212-450$ & $1078-1133$ & $1143-1198$ & 3 & 9.4 & 13.0 \\
\hline & & $x$ & & 0 & $24(51.0)$ & 24 & 550 & 567 & $7\urcorner 4$ & 3 & 12.0 & 16.5 \\
\hline
\end{tabular}

(a) Maximum ${\overrightarrow{C_{\hat{G}}}}=800^{\circ} \mathrm{C}\left(1472^{\circ} \mathrm{F}\right)$

(b) Maximum $T_{\hat{L}}=660^{\circ} \mathrm{C}\left(1220^{\circ} \mathrm{F}\right)$

(c) Helium in overpack gap

(d) Emissivity of all surfaces 0.9

The sizing and costs of plants will be developed for the boiler tubeoverpack-canister wal 1 for Concept 1 and the bare canister wall for Concept 2. At this time it is uncertain whether the canister wall can be considered a barrier (due to the high temperatures the wall experiences during waste solidification). Concept 1 assumes an overpack is required for canister integrity and licensing (see Section 8.1); if an overpack is not required, the capital cost (steam plant size) will be slightly reduced. Also, if an overpack is required, the costs of Concept 2 will slightly increase. A canister diameter of 20 in. or more will be considered only 
in Concept 2 since addition of an overpack and boiler tube as in Concept 2 would increase the centerline temperatures of this size canister above the maximum. The results for calcine will include an overpack for both concepts due to the relatively high leachability of the calcine.

When the canister diameters and waste forms are further specified for waste disposal methods, Table 8.3 and Appendix B should provide information on the effects on temperature distributions and boiler sizes.

\subsection{STEAM PLANT SIZE}

The overall size of the steam plant is a function of waste form, canister diameter, boiler concept, and canister storage time. Table 6.2 of Section 6.0, "Strategies for Army Canister Use," presents various schemes for use of canisters in a 5-MW steam plant based on canister diameter, waste form, supply rate, and storage time. At the end of the canister storage time, it is specified in the tabie whether the preliminary salt mine criteria are met by the canister. Since it would be an overall economic advantage to the nuclear fuel cycle to have the canisters only stored in an Army steam plarit (i.e., no requirement for an RSSF before canister disposal), the cases where the prelimiriary salt mine criteria are met or closely met will be the ones where cost estimates for a steam plant will be developed. The canister centerline temperatures are also limiting in some cases; for example, the centerline temperature of the $24 \mathrm{in}$. diameter borosilicate glass canister exceeds $800^{\circ} \mathrm{C}\left(1472^{\circ} \mathrm{F}\right)$ in both concepts 1 and 2 .

Using the resuits of Table 6.2 and Table 8.3, the steam plants which will receive further consideration in design and costs are presented in Table 8.4. Concept 1 is based on $350^{\circ} \mathrm{F}$ working fluid and Concept 2 is based on $450^{\circ} \mathrm{F}$ working fluid. Calculations were made with $550^{\circ} \mathrm{F}$ working fluid to consider a reduction in size and cost of the secondary heat exchanger in Concept 2; however, the increase in pressure at $550^{\circ} \mathrm{F}$ caused the savings on the exchanger to be minimal compared to the potential increased costs of the pressure heads. Included in this table are the size of the boilers, number of boilers, and dimensions of the boiler area based on the boiler layouts in Figure 8.5. The depths of the water basins are $25 \mathrm{ft}$ for the 


\section{TABLE 8.4. 5-MW Steam Plant - Boiler and Plant Dimensions}

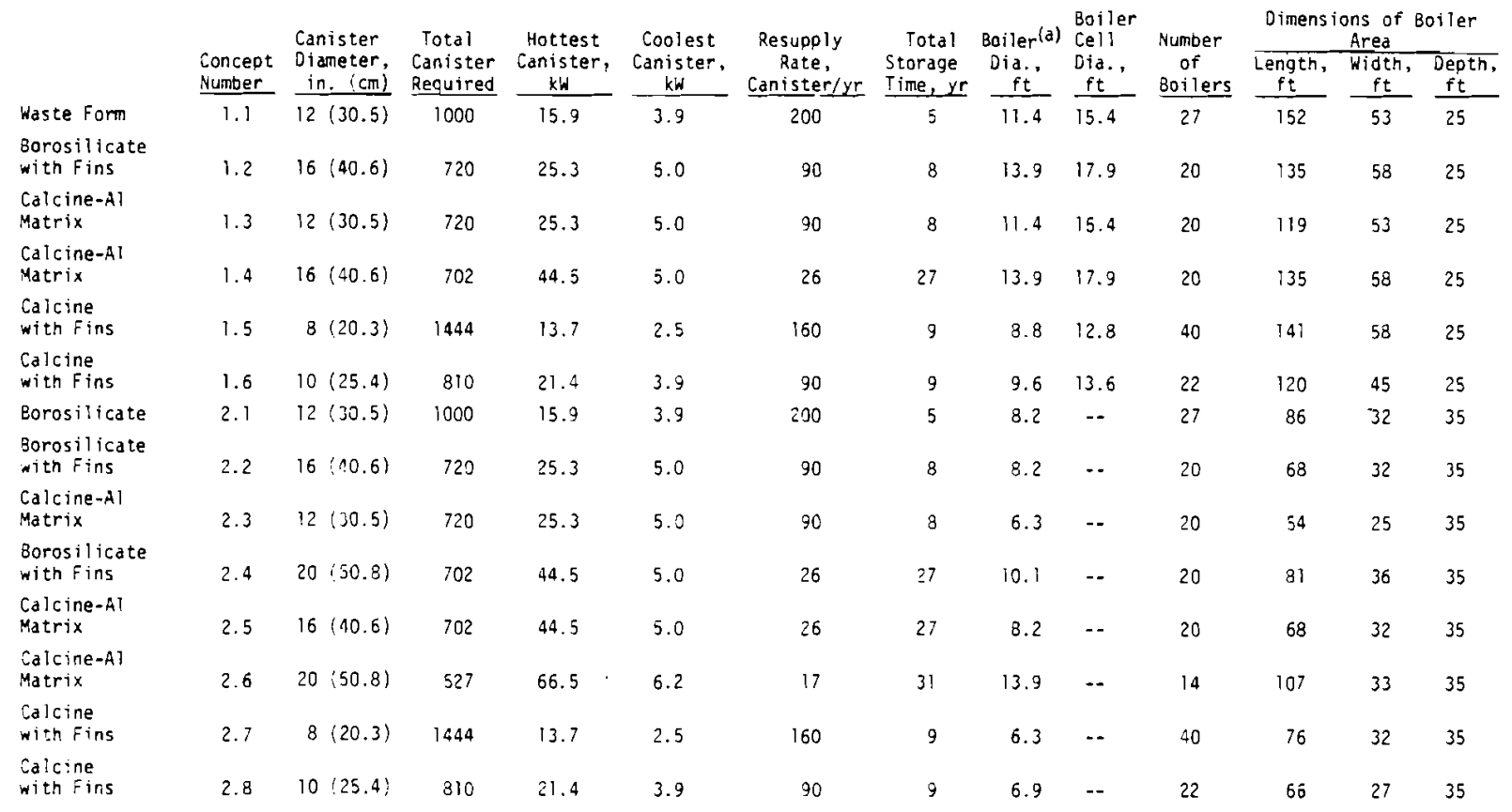

(a) Distance betmeen boiler tubes is $3 \mathrm{in}$.
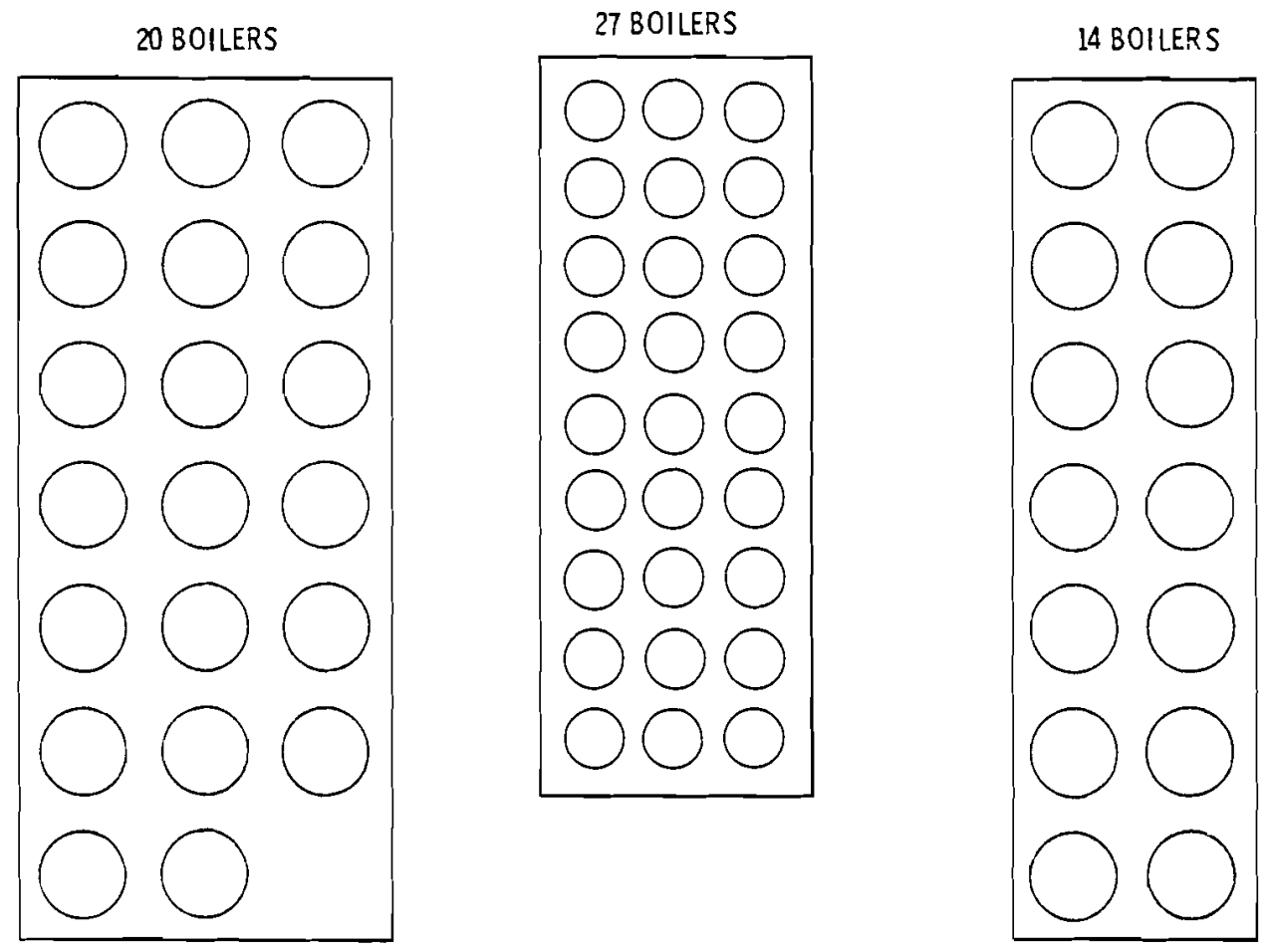

FIGURE 8.5. Boiler Layout 
Concept 1 and $35 \mathrm{ft}$ for Concept 2. Concept 1 includes a cell dimension which allows $2 \mathrm{ft}$ around the boiler sides for inspection and possible removal of the boiler for maintenance. For the boiler area dimensions (length and width) $2 \mathrm{ft}$ of concrete is included around the outer sides and $1 \mathrm{ft}$ is included between the boilers.

The total boiler facility for both concepts includes such items as a pipe trench, a building around the boilers, and a 50-ton crane. In Figure 8.6 the specific dimensions for Concept 2.2 are given. This is based on the work of the Atlantic Richfield Hanford Co. (ARHCO) on the RSSF Water Basin Concept. (For more detailed drawings the reader is referred to Figures 11-20 to 11-25 in ARH-2888 Rev. Reference 4.) In Figure 8.7, the details of the boiler of Concept 1.2 are presented (which are the same for Concept 1.4).
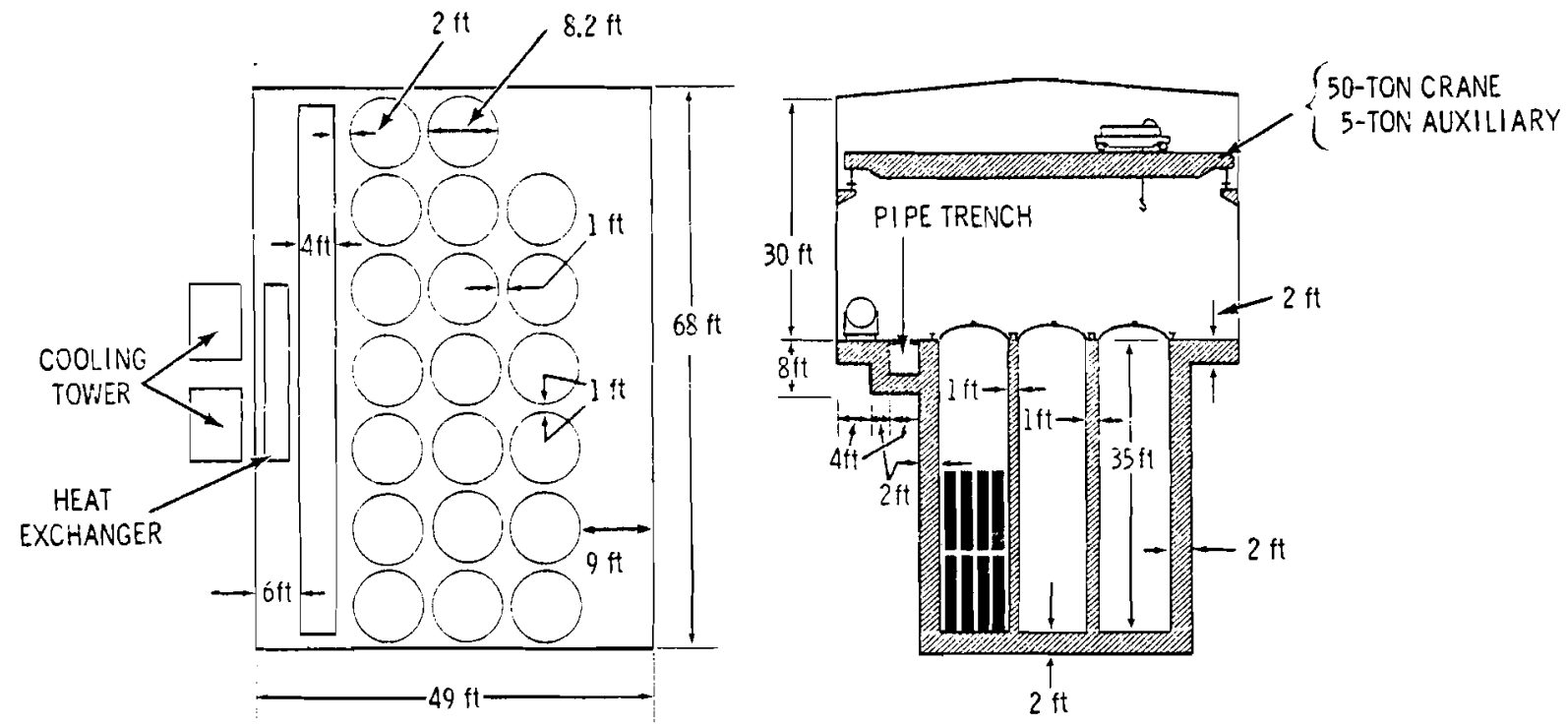

FIGURE 8.6. Boiler Facility (Details of Concept 2.2) 


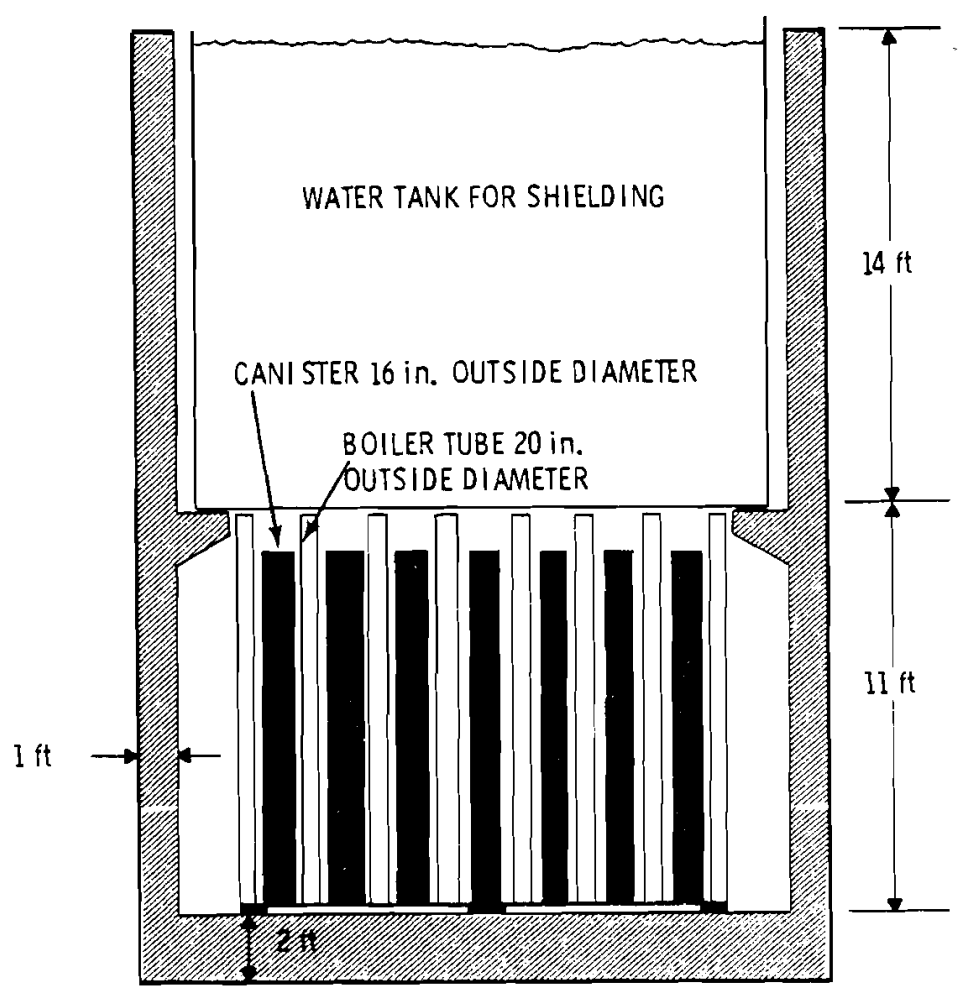

$13.9 \mathrm{ft}$

$17.9 \mathrm{ft}$

FIGURE 8.7. Boiler with Water Tank for Shielding (Details for Concept 1.2 and 1.4)

As discussed in Section 7.0 entitled "Licensing and Safety", the canister Receiving Facility base design will use a water basin for transfer of canisters between the shipping cask to the transport cask. The details of this water basin are given in Figure 8.8. Stainless steel lines the entire basin and impact absorbers are placed in each cask well. The layout and size of the entire Receiving Facility is presented in Figure 8.9. This is once again based on ARHCO'S RSSF work with modifications made to the RSSF Receiving Facility, namely: the facility size is reduced to account for a much smaller rate of canister delivery/shipment at the Army steam plant in which cranes are used totally for cask handling, and the cask transfer is accommodated by the water basin. Special doors are required for the Receiving Facility in Figure 8.9 to enable the 125- and 50-ton cranes to enter 

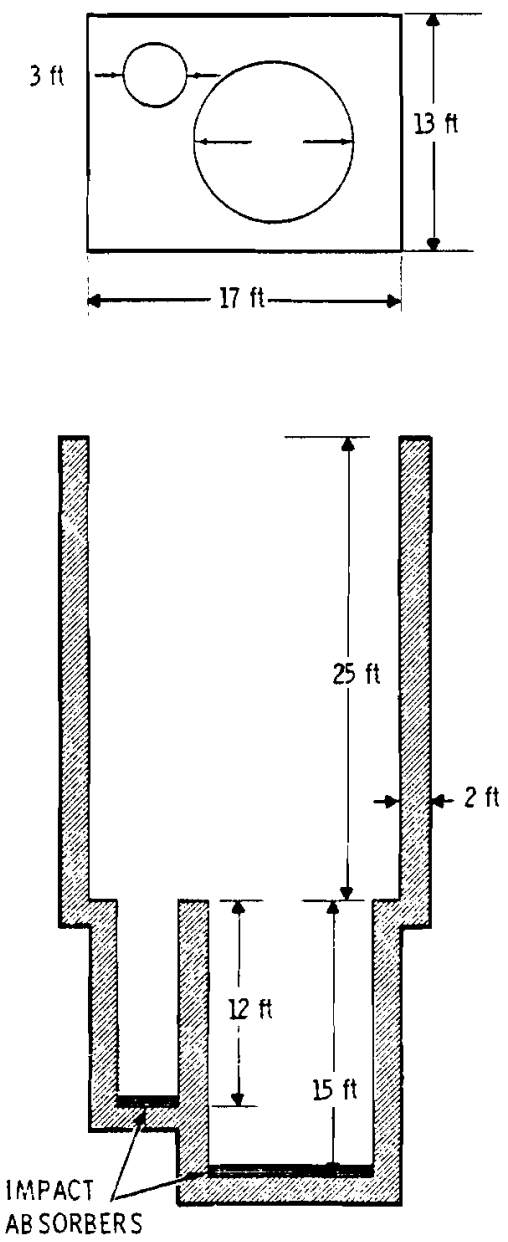

FIGURE 8.8. Water Basin for Canister Handling

the cask transfer area. The 36- by 25-ft doors are required to seal off the area when handling potential leaking canisters. Another item, which is stainless stee 1 lined is the 15 - by 20 - by 5 -ft decontamination pit; the transport cask is placed in the pit for decontamination, inspection, and c001down. The walls of critical areas (electrical, operating, and generator and battery) have 1-ft thick concrete walls and roofs. All other structures are the same as for the Boiler Facility Building; if further information on certain features of this modified Receiver Facility are desired, the reader is referred to Figures $11-21$ and 11-29 of ARH-2888 REV. (4) 


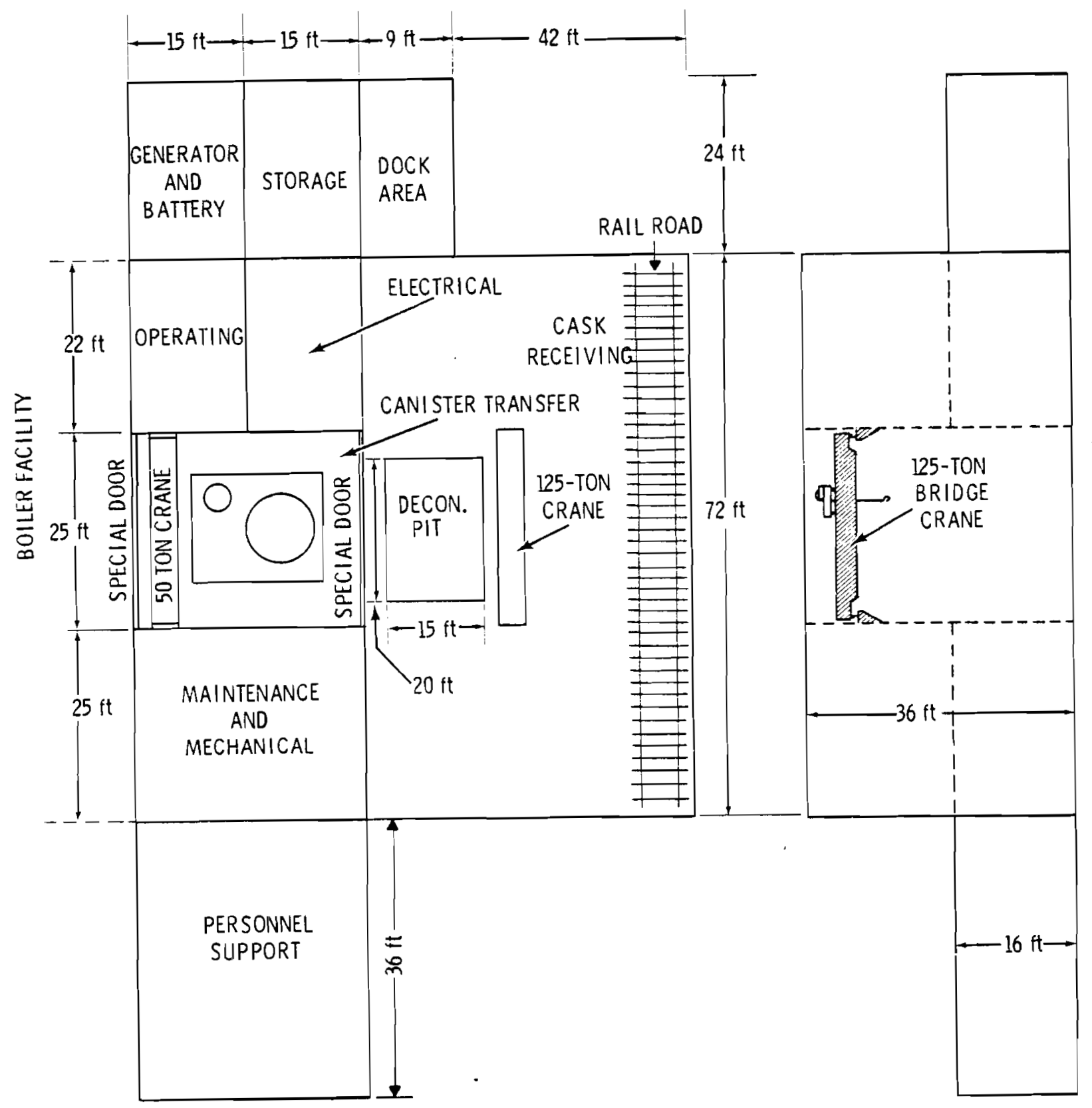

FIGURE 8.9. Receiver Facility 
As mentioned previously, the RSSF Receiver Facility contained a hot cell and more elaborate capabilities than those provided for the facility shown in Figure 8.9. This latter facility is considered to be the minimum acceptable from a licensing/safety standpoint provided the receipt of contaminated canisters and the leaking of canisters during storage are extremely infrequent occurrences. This assumption is strongly dependent on the canister design and qualification program. If it is desirable to build an Army steam plant before the canister qualification program is completed or if future decisions so regulate, a Receiving Facility similar to the RSSF hot cell receiving may be required (see Figure 11-21 and others in ARH-2888 REV.) ${ }^{(4)}$ Therefore, a cost estimate (see Section 10) for the RSSF type receiving facility along with one for the minimum facility shown in Figure 8.9 will be included in the present analysis.

\subsection{STEAM PLANT OPERATION}

The receiving and shipping of the HLW canisters are identical for both Concepts 1 and 2. A rail car carrying the transport cask will enter the facility on the tracks, where it will be uncoupled from the locomotive. A roll-down door will seal the Cask Receiving area. Then, the 125-ton crane will remove the cask from the rail car and place it in the decontamination pit. The outside of the cask will be monitored, the road dirt will be washed down, and the cask will be decontaminated and cooled down if necessary. A check will be made on the integrity of the canisters still sealed in the cask; the method will depend on cask design. Any canisters suspected of poor integrity will be returned to the fuel reprocessing plant, although this is assumed to be an infrequent occurrence. The lid of the transport cask will then be loosened and readied for opening. Next, the special door between the Cask Receiving area and the Canister Transfer area will be opened and the 125-ton crane will carry the transport cask into the Canister Receiving area, the special door will be closed, and the cask will be placed in the large cask well in the water basin. The cask lid will be removed by the 125-ton crane. The canister will be removed by a 5-ton auxiliary crane, monitored once more, and placed in the transfer cask (which is already in 
position). The transfer cask will be closed, decontaminated as it is removed from the water basin by the 50-ton crane, and transported through the open special door into the Boiler Facility. Here, the main 50-ton crane for the Boiler Facility, which is on a more elaborate rail system in order to service the larger boiler area, will take the transfer cask to the boiler being refueled. The fresh canister will be placed in the boiler, and an aged canister will be removed. The transport cask will be returned to the water basin and the canister will be put into the large transport cask. If needed there is available space in the water basin (see Figure 8.8) to store both aged canisters and fresh canisters. The transport cask will be filled with aged canisters, the lid replaced, decontaminated as it leaves the water basin, further decontaminated and prepared for shipment in the decontamination pit, and then shipped to the high-level waste disposal site with its load of aged canisters.

The following capabilities will be provided for both Concepts 1 and 2 and will be similar to the RSSF Water Basin Concept design:

- Emergency cooling and excess heat dump will be by a secondary cooling loop employing pumps, plate type heat exchangers, and cooling towers.

- Water basin decontamination will use ion exchangers and waste tanks.

- Emergency power will be provided by diesel generators.

- Basin water and primary system water will be maintained at less than $10 \mathrm{ppm}$ chloride concentration by a water treatment system.

- Interior walls of the Boiler Facility and Canister Transfer area will receive a special coating to assist potential decontamination procedures.

- Low-level radioactive waste processing will employ cement filled containers (if experience indicates that considerable contaminated liquid waste requires handling, a waste concentrator may be installed at a later time).

- The ventilation system for the Receiver and Boiler Facility will have HEPA filters and radiation monitors.

Refueling in Concept 1 will take place by first cooling the working fluid boilers and canisters by using the cooling tower system. The boiler 
cell will be filled to provide shielding. The shielding tank may be either emptied by a portable pump and allowed to float up as the cell is filled or a plug can be removed from the tank bottom; in the latter case the shielding tank will empty as it is removed by the 50-ton crane. The crane will transfer the shielding tank to the side area for storage. The water in the basin cell and boiler will be maintained at $120^{\circ} \mathrm{F}$ or below by the cooling system. A transfer cask will be lowered into the water filled boiler cell by the 50-ton crane and placed over the boiler tube. A cable and hook passing through the cask cavity will then be lowered and attached to a canister. The 5-ton auxiliary crane will raise the canister into the cask, the cask's lower end will be closed, and the 50-ton crane will remove the cask from the cell for transport to the Canister Transfer area. This transport cask will require special design to eliminate radiation shine around the cable which passes through the cask and special consideration for the bottom cap. The alternative to a specially designed transport cask is to have cask wells in each boiler cell as in the canister transfer water basin (see Figure 8.8). If cask wells were installed, an additional 10 to $11 \mathrm{ft}$ of depth to the boiler cell would be required to provide shielding as the canister is pulled out of the transfer cask and moved horizontally over a boiler tube. The incremental cost of providing cask wells for each boiler cell would be significant (increased stainless steel liner, concrete, etc.). Therefore, the existence of a special cask will be assumed. Also, the special transport cask would eliminate the need for a transport cask well in the transfer water basin, but in this case the cost savings would be minimal.

Refueling in Concept 2, would necessitate cooling the working fluid to $120^{\circ} \mathrm{F}$ and pressure reduction to atmospheric pressure. The secondary cooling loop will cool the liquid by the plate-type heat exchangers and cooling towers. This will, in turn, reduce the boiler pressure. Since the vapor and liquid in the boiler will be in equilibrium once $212^{\circ} \mathrm{F}$ is reached, vent air will be introduced into the boiler since further cooling would cause a vacuum. Once the boiler is cooled and depressurized, the boiler head can be unbolted, removed by the 50-ton crane, and stored in the side storage area. Cooling will be maintained while the head is off with 
the secondary cooling loop. The top row of canisters will be removed as in Concept 1 with a special transport cask. The second row will be removed by using gates in the storage racks. Since only a 3 in. clearance between canisters has been allowed in the boiler design, this spacing may need to be increased in future design for the storage racks. Also, a cask well could be used, in this boiler, instead of a special cask; however, extra depth to the boiler would not be required if a cask well were installed since gates in the storage rack could allow site entrance into the storage array.

\subsection{DESIGN UNCERTAINTIES}

Since this study is for economic feasibility and not detailed design, there are some design uncertainties which will be listed here and were accounted for in the cost estimates by uncertainty factors (the amounts are similar to those used in the RSSF estimates).

- Concrete temperature - the stability of 350 to $450^{\circ} \mathrm{F}$ concrete must be considered in future design. If this is a problem either insulation, special concrete, or concrete cooling could be used.

- Insulation - boiler insulation amounts and costs were not included, but would probably have a minimal impact on overall cost.

- Structure - the cell and boiler structure had $1 \mathrm{ft}$ of concrete between adjacent units to minimize costs. Either more than $1 \mathrm{ft}$ or a stronger (more costly) concrete may be required.

- Stainless steel liner as pressure vessel walls - this was assumed for Concept 2 cost estimates. Possibly a thicker walled liner may be required. If the entire boiler had to be prefabricated, the boiler costs could increase significantly.

- Materials - the corrosion and strength of the steels used in the boiling water environment must be considered. Boiling may promote stress corrosion cracking due to chlorine concentrating at the boiling surface. Chlorine concentration will probably have to be controlled below 10 ppm. (25) 
- Hydrogen Control - hydrogen buildup in the system will be caused by radiolysis of water. (4) Its removal must be assured.

- Secondary Containment Envelope - For licensing, either a soil impervious to water flow or a secondary containment envelope around the boiler facility may be required. (25) This would depend on the soil characteristics and hydrology at the specific site. If a secondary envelope were required, the cost increase could be significant.

- Hot Cell Receiving - For a 10-MW and 20-MW steam plant, a water basin receiving facility may not be able to accommodate the increased canister delivery rate; a hot cell receiving facility might be more economic than an expanded water basin receiving facility. Also, it may be easier to 1 icense a hot cell than a water basin receiver depending on the quality of canister and decontamination required. The cost of this change in design is included in Section 10 - Economics.

After a discussion on canister transportation, the costs of these plants are calculated. 
$+$

,

. 
9.0 TRANSPORTATION 


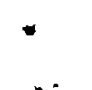

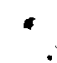
$\therefore$ 


\subsection{TRANSPORTATION}

This section considers the transportation of high-level waste canisters from: 1) a nuclear fuel reprocessing plant to postulated thermal power plants at seven U.S. Army installations and then following this use, onto two possible final disposal sites (indirect shipment), and 2) the nuclear fuel reprocessing plant directly to two possible final disposal sites (direct shipment).

Current regulations are described and a projection is made of potential future regulations pertaining to the shipment of radioactive materials and their possible effects on the total transportation costs. The costs of transportation are detailed for $40.6 \mathrm{~cm}$ (16 in.) diameter borosilicate glass canisters containing eight internal fins (Concepts 1.2 and 2.2) and transportation costs for the other concepts are summarized.

\subsection{REGULATIONS-TRANSPORTATION OF RADIOACTIVE MATERIALS}

Current Federal Regulations (see Part 50, Appendix F of Reference 7) require that high-level liquid radioactive wastes be converted to a dry solid not later than $5 \mathrm{yr}$ after the fission products have been separated from the irradiated fuel. The solidified waste must be shipped from the reprocessing plant to a Federal repository not later than $10 \mathrm{yr}$ after the waste has been separated from the fuel. Shipments of solidified high-level wastes must also conform to Federal regulations for the shipment of radioactive material.

\section{Federal Regulations}

The safety of shipping radioactive materials depends primarily on package designs of high integrity rather than control of the accident environment. (26) Regulations govern the transportation of radioactive materials to prevent the loss or dispersal of materials during shipment and to insure the safety of the public transportation workers. But, responsibility for regulating the safe transport or radioactive materials overlaps. 
The primary Federal responsibility lies with the Department of Transportation (DOT) Materials Transportation Bureau and the Nuclear Regulatory Commission (NRC). A "Memorandum of Understanding" between the two agencies signed in 1966 and revised in $1973^{(27)}$ calls for cooperation between DOT and NRC and delineates the responsibilities of each agency. DOT is responsible for promulgating and enforcing safety standards governing packaging and shipping containers, and for the labeling, classification and marking of all packages. DOT also implements safety standards for the mechanical condition of carrier equipment and qualifications of carrier personnel. NRC develops performance standards for package designs and reviews package designs for Type $B$, fissile and large quantity packages. DOT requires NRC approval to use these packages. (28)

The transportation or packaging for transport of radioactive material is subject to issuance of the appropriate licenses. Applicants for a license to package or to transport radioactive material must show by a combination of analysis and experiment that the proposed package or transport vehicle satisfies all the requirements set forth in the Code of Federal regulations. The application must describe proposed controls or precautions to be used in the loading, unloading, handling and transport of radioactive material and the procedures to be followed in the event of an accident or delay in shipment. Inspection and accountability procedures must also be described.

Significant regulatory constraints which affect high-level wastes shipment include:

- Type B packaging capable of satisfying the accident test criteria (summarized below) of 10 CFR $71^{(7)}$ and 49 CFR 173.398. (29)

- Limitation of the dose rate to $10 \mathrm{mrem} / \mathrm{hr}$ at a distance of $6 \mathrm{ft}$ from the external surface of the transport vehicle.

- Limitation of the accessible cask surface temperature to $82^{\circ} \mathrm{C}$.

Also hypothetical transportation accident tests are applied sequentially to determine cumulative effect on the package. These include the following: 
- Free drop - through a distance of $9.1 \mathrm{~m}$ onto an unyielding surface, striking the surface in the position which would produce maximum damage.

- Puncture - a free drop through a distance of $1 \mathrm{~m}$ onto a cylindrical steel bar $15.2 \mathrm{~cm}$ in diameter with the edge rounded to a radius of $6.4 \mathrm{~mm}$. The length of the bar is selected for maximum damage (minimum length is $20.3 \mathrm{~cm}$ ). The bar is mounted on an unyielding horizontal surface and the package is dropped in a position expected to produce maximum damage.

- Thermal - exposure to the equivalent of a $800^{\circ} \mathrm{C}$ fire for $30 \mathrm{~min}$ with no artificial cooling for $3 \mathrm{hr}$ after the exposure.

It is anticipated that the U.S. Regulations on radioactive material packaging will be changed in the near future to agree in substance with 1973 International Atomic Energy Agency (IAEA) Regulations. It is not expected that these relatively minor regulation changes will affect the economics of transporting the waste material.

State and Local Regulations

Although Federal agencies dominate the regulatory process for the transportation of radioactive materials, state and local governments also exercise some control over these shipments. State highway departments regulate gross vehicle weights, vehicular dimensions and other parameters for radioactive shipments just as they do for other kinds of shipments. About one half of the states have adopted the U.S. DOT Hazardous Materials Regulations to cover intra-state shipments. Several states have adopted or proposed additional regulations concerning radioactive materials. $(27,30)$ These include:

- Special routing of radioactive shipments

- Advance notification for shipments of large quantities of materials

- State inspections of some types of radioactive shipments

- Prohibition of certain types of radioactive shipments 
- Prior approval for radioactive shipments

- Requirement of exclusive vehicle use for radioactive shipments

- Use of pilot vehicles

- Speed restrictions for radioactive shipments

- Specific hours of movement

- Accompaniment of a 11 shipments by radiation monitoring personnel.

The variation of regulations between adjacent states could impede the waste shipments. There is a potential conflict between some of the proposed and existing state and local laws and the provisions of the National Transportation Act of 1974. (Public Law 93-633 signed in 1975). This law prohibits the states from adopting laws or regulations more stringent than Federal regulations unless the state regulations improve transportation safety. Even in this case, such rules can be adopted only if they do not unreasonably burden commerce. The legality of some of the state and local regulations is currently being contested in the courts.

Railroad Transport Constraints

The railroads are seeking to require that special trains be used to transport radioactive materials for reasons of public health and safety, even though special train service is not required by Federal regulations. The Association of American Railroads supports this position. The railroads argue that the stress and accident tests performed on the casks used for transportation of these materials do not approach actual railroad operating conditions. The major elements of special train service are as follows: 
- No other type of freight is handled on these special trains.

- Special train speeds are restricted to a 35 miles per hour maximum.

- When a train handling one of these shipments passes or is passed by another train, one train must come to a standstill while the other passes at no more than 35 miles per hour.

There are a number of proceedings ${ }^{(31)}$ pending before the Interstate Commerce Commission which involve the transportation by rail of radioactive materials. These proceedings involve the shipment of spent nuclear fuel and radioactive waste material. The main issues in these proceedings are to determine whether environmental and safety considerations justify the railroad's proposed requirement that spent nuclear fuel and radioactive waste material be moved in special trains as opposed to regular train service and to determine whether the practice by railroad companies not to participate in the tariff is lawful. Pressure may be applied to require the use of special trains, but it is not likely that nonparticipation practices by railroad companies will be found to be lawful.

\subsection{ARMY TRANSPORT DESCRIPTION}

The transportation of the canisters for concepts 1.2 and 2.4 will be detailed here and the results for other concepts will be summarized. The waste is solidified in stainless steel canisters with a 16 in. diameter and $10 \mathrm{ft}$ length. The waste is shipped to the Army facility at $2 \mathrm{yr}$ of age and then stored for $8 \mathrm{yr}$. Finally, the 10-yr-old waste is shipped to the disposal site. The initial heat loading of 2-yr-old borosilicate glass (with fins) in $40.6 \mathrm{~cm}$ (16 in.) diameter - $305 \mathrm{~cm}$ (10 ft) long canisters in $25.3 \mathrm{~kW} / \mathrm{can}$ and the heat loading of the $10-\mathrm{yr}$ old waste is $5.0 \mathrm{~kW} / \mathrm{can}$. The Army facility has a resupply rate of 90 canisters/ year when operating at steady-state conditions. The total number of canisters (ranging in waste age from 2 to $10 \mathrm{yr}$ ) required for a 5 - MW steam plant ( $80 \%$ efficient) is 720. After use, these canisters would meet the preliminary salt mine criteria. 
Radioactive material shipments in the United States are generally made by truck or train. Truck shipments are limited to a 73,000-1b total weight of the truck and the load. Without overweight permits a loaded cask for this mode can weigh a maximum of about 48,000 to $50,000 \mathrm{lb}$. The cask weight for carrying one canister exceeds this limit; therefore, this mode is not considered in this analysis.

Overweight truck transportation, involving vehicle weights of up to about 110,000 1b is possible. Overweight truck transportation requires obtaining an overweight permit in each state through which the cask is shipped; varying degrees of difficulty are encountered when obtaining these permits (e.g., some states will not issue overweight permits during spring thaw months). The extra costs, time delay, and restrictions associated with overweight truck shipment reduces the feasibility of this mode of transportation substantially. Therefore, overweight truck shipment is not considered in this analysis.

The casks used for rail shipment weigh approximately 100 tons. Rail shipments appear to have advantages over truck shipments since the larger casks improve the material to shipping container weight ratio.

The solidified waste form is assumed to be zinc borosilicate glass. A canister containing 2-yr-old waste with a $16 \mathrm{in}$. diameter and $10 \mathrm{ft}$ length requires a lead gamma shielding thickness of approximately 9 in. (32) The weight of the loaded cask is expected to be about 48 tons which exceeds the legal weight requirements of truck shipment. Thus, the mode of transportation used in this cost analysis is rail shipment.

A conceptual design of a high-level solid radioactive waste shipping cask and rail car assembly is shown in Figure 9.1 (provided by P. L. Peterson, PNL). The canisters are stored and transported in high-level waste shipping casks. One conceptual design for a high-level waste shipping cask is about $7 \mathrm{ft}$ in diameter and $15 \mathrm{ft}$ long and would accommodate six 16 in. diameter by $10 \mathrm{ft}$ long waste canisters. The maximum internal heat load of the cask is about $50 \mathrm{~kW}$. 


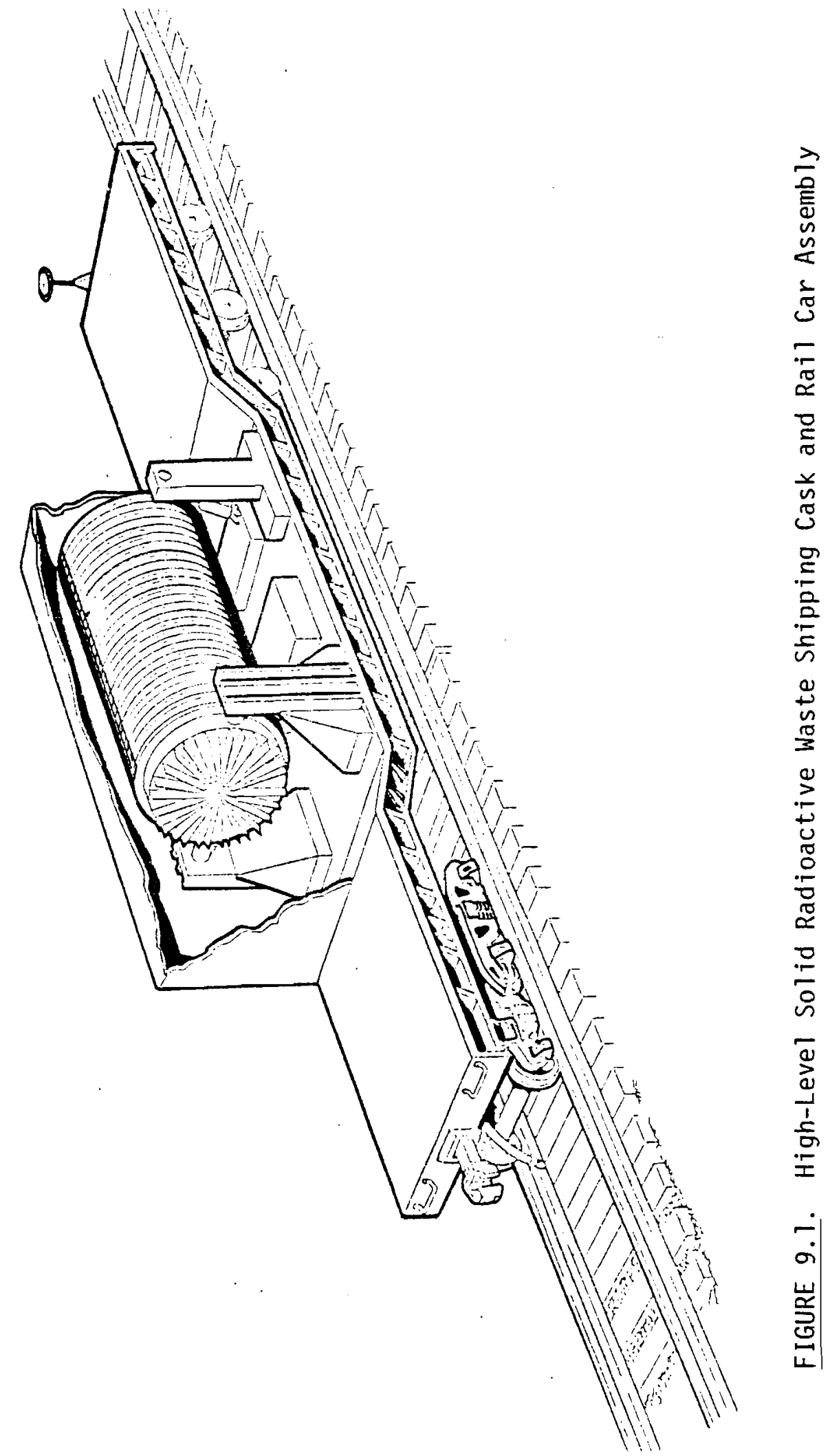


The transportation cost estimates are based on 1976 dollars. It is assumed that 2-yr-old waste is loaded at two canisters per cask. Thus, 45 cask-trips/yr are required for an Army facility operating at steadystate conditions. Each canister holds about 4.4 metric tons (MT) of waste. The 10-yr-old waste, because of its lower radiation levels and heat output, is assumed to be shipped at six canisters per cask and that special trains are required for the shipment of these casks; Table 9.1 summarizes the assumptions used in this study. The major elements of special train service are:

- No other type of freight is handled on these special trains.

- Special trains are restricted to a 35 miles per hour maximum.

- When a train handling one of these shipments passes or is passed by another train, one train must come to a standstill while the other moves past at no more than 35 miles per hour.

\section{TABLE 9.1. Summary of Assumptions Used in Cost Analysis}

1. Canister Features - $16 \mathrm{in.} \mathrm{diameter} \mathrm{and} 10 \mathrm{ft}$ long with internal fins

2. Waste Form - borosilicate glass

3. Age of Solidified waste $-2 \mathrm{yr}$

4. Waste Availability - Starting in 1976

5. Canisters per Cask - (2-yr-old waste) Two

$$
\text { - (10-yr-old waste) Six }
$$

6. Number of Steam Plants in Operation - One

7. Transportation of Waste - Rail shipment

- Special trains required for loaded and unloaded cask shipment

- 3 day turnaround time for all the casks at each end of shipment (a)

- Special train transit time is the same as regular train transit time

- Cask use charge, \$2500/day (loaded or empty)

- Class 40 rates apply for loaded cask shipment

- Class 37 1/2 rates apply for empty cask shipment

(a) The estimated time to load and unload three casks is about 3 days. 
Possible steam plant locations considered in this study are listed below which provide typical transportation distances.

- Red Stone Arsenal, Huntsville, Alabama

- Fort Bragg, Fayetteville, North Carolina

- Fort Benning, Columbus, Georgia

- Fort Hood, Killeen, Texas

- Fort Meade, Baltimore, Maryland

- Fort Carson, Colorado Springs, Colorado

- Fort Lewis, Tacoma, Washington

The fuel reprocessing plant location is based on the AGNS plant at Barnwell, South Carolina. Presently there are no permanent disposal sites for highlevel waste in the United States. But, in order to obtain characteristic transport distances, two possible sites, ${ }^{(33)}$ Alpena, Michigan, and Carlsbad, New Mexico, are used as representative permanent disposal site locations. The waste shipment origins and destinations used in this study are shown in Figure 9.2.

BARNWELL, SOUTH CAROLINA

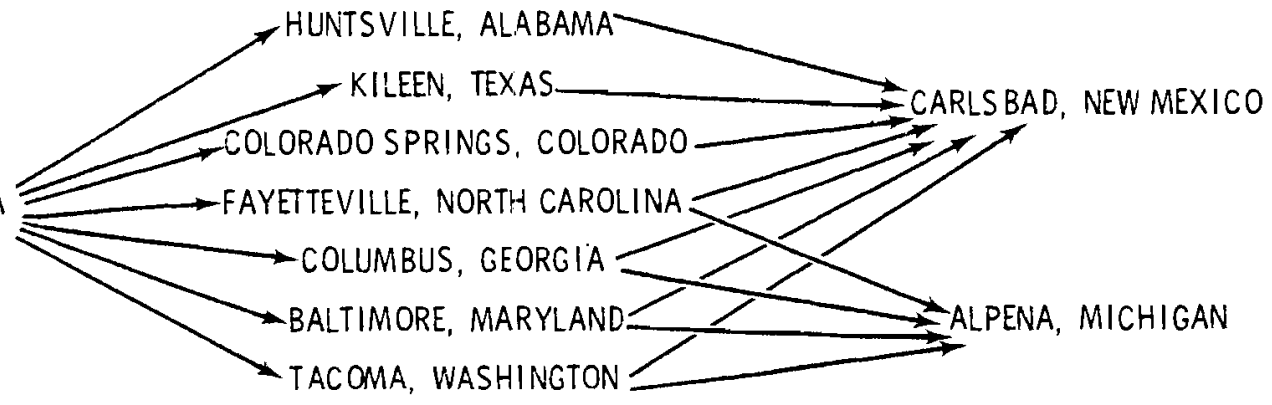

FIGURE 9.2. Transportation Origins and Destinations for Waste Canister Shipment 


\subsection{TRANSPORTATION COSTS}

A summary of estimated 1976 freight charges, train miles, special-train charges, and transit times $(a)$ is presented in Table 9.2. $(b)$ The railroad class rates applicable to the shipment of solidified high-ievel waste, special car and cask combination charges, are summarized below. $(b, c)$

A - Loaded: (1) Item 80762, Uniform Freight Classification 12 (UFC-12) Declared Valuation less than $\$ 0.40 / 1 \mathrm{~b}$ - Class 40 rate.

(2) Item $80768 \mathrm{~A}$, Note 3, UFC-12

Eastern Railroads plus a few others do not participate in the tariff and require a special contract.

(3) Item $80769 \mathrm{~A}$, Note 4 , UFC-12

Class rates apply against minimum net weight of $240,0001 \mathrm{~b}$ for each car.

(4) Item 80769.5 , Note 5 , UFC-12

Class rates are only applicable on shipments moving in special freight train service subject to provisions of applicable special freight train service tariffs.

B - UnToaded: (1) Item 81295B, UFC-12

Cars radioactive materials shipping, moved on own wheels Class $371 / 2$

Subject to $225,000 \mathrm{lb}$ minimum for each car.

(2) I tem $81297 \mathrm{~B}$, Note $51 / 2, \mathrm{UFC}-12$

Contains further description of car and cask combination.

(a) Assumes special train transit times are the same as regular train transit times.

(b) This information was obtained from the appropriate railroads.

(c) W. V. Loscutoff, PNL. 


\section{TABLE 9.2. Sunmary of Estimated Freight Charges, Train-Miles, Special-Train}

Charges, and Transit Times (1976)

\begin{tabular}{|c|c|c|c|c|c|c|c|c|c|c|}
\hline \multirow[b]{2}{*}{ Origin } & \multirow[b]{2}{*}{ Destination } & \multirow{2}{*}{$\begin{array}{l}\text { Originatjng } \\
\text { Railroad d) }\end{array}$} & \multicolumn{2}{|c|}{$\begin{array}{l}\text { Freight Rate, } \\
\$ / 1001 \mathrm{bs}(\mathrm{a}, \mathrm{b}) \\
\end{array}$} & \multicolumn{2}{|c|}{$\begin{array}{l}\text { Freight Charge, } \\
\$ / \text { car }(a, b, c)\end{array}$} & \multirow{2}{*}{$\begin{array}{c}\text { Estimated } \\
\text { Train- } \\
\text { Miles }\end{array}$} & \multirow{2}{*}{$\begin{array}{c}\text { Special Train } \\
\text { Charges }(e) \\
\$ / \text { Mile }\end{array}$} & \multirow{2}{*}{$\begin{array}{c}\text { Estimated } \\
\text { Special-Train } \\
\text { Charge, } \\
\$ 11-\text { Way }(a, b)\end{array}$} & \multirow{2}{*}{$\begin{array}{c}\text { Estimated } \\
\text { Iransit Time } \\
\text { Days }\end{array}$} \\
\hline & & & Class 40 & Class $37-1 / 2$ & Class 40 & Class $37-1 / 2$ & & & & \\
\hline $\begin{array}{l}\text { Barnwell } \\
\text { SC }\end{array}$ & $\begin{array}{l}\text { Carlsbad } \\
\text { NM }\end{array}$ & SCl. & 5.46 & 5.11 & 13,160 & 11,500 & 1475 & 13.96 & 27,970 & 10 \\
\hline $\begin{array}{l}\text { Barnwel1 } \\
\text { SC }\end{array}$ & $\begin{array}{l}\text { Alpena } \\
\text { MI }\end{array}$ & $\mathrm{SCL}$ & 4.62 & 4.33 & 11,090 & 9,740 & 1158 & 19.13 & 22,150 & 9 \\
\hline $\begin{array}{l}\text { Barnwe11 } \\
\text { SC }\end{array}$ & $\begin{array}{l}\text { Huntsville } \\
\text { AL }\end{array}$ & $S C L$ & 2.30 & 2.61 & 6,720 & 5,870 & 494 & 18.96 & 9,370 & 3 \\
\hline $\begin{array}{l}\text { Barnwell } \\
\text { SC }\end{array}$ & $\begin{array}{l}\text { Killeen } \\
\text { TX }\end{array}$ & SCL & 4.61 & 4. 31 & 11,060 & 9,700 & 1113 & 18.96 & 21,100 & $91 / 2$ \\
\hline $\begin{array}{l}\text { Barnwell } \\
\text { SC }\end{array}$ & $\begin{array}{l}\text { Colorado } \\
\text { Springs, co }\end{array}$ & SCL & 5.70 & 5.36 & 13,680 & 12,060 & 1865 & 18.96 & 35,360 & 8 \\
\hline $\begin{array}{l}\text { Barnwel 1 } \\
\text { SC }\end{array}$ & $\begin{array}{l}\text { Fayetteville } \\
\text { NC }\end{array}$ & $S C L$ & 1.94 & 1.81 & 4,660 & 4.070 & 200 & 18.96 & 3,790 & $1 / / 2$ \\
\hline $\begin{array}{l}\text { Barnwell } \\
\text { SC }\end{array}$ & $\begin{array}{l}\text { Columbus } \\
\text { GA }\end{array}$ & $\mathrm{SCl}$ & 2.19 & 2.03 & 5,260 & 4,680 & 369 & 18.96 & 7.000 & $21 / 2$ \\
\hline $\begin{array}{l}\text { Barnwell } \\
\text { SC }\end{array}$ & $\begin{array}{l}\text { Balt timore } \\
\text { MD }\end{array}$ & $\mathrm{SCL}$ & 3.17 & 2.99 & 7,610 & 6,730 & $45 ?$ & 18.96 & $10,090(f)$ & $31 / 2$ \\
\hline $\begin{array}{l}\text { Barnwe11 } \\
\text { SC }\end{array}$ & $\begin{array}{l}\text { Tacoma } \\
\text { WA }\end{array}$ & $\mathrm{SCL}$ & 10.12 & 9.49 & 24,290 & 21,350 & 3259 & 19.18 & 62,510 & 10 \\
\hline $\begin{array}{l}\text { Huntsville } \\
\text { AL }\end{array}$ & $\begin{array}{l}\text { Carlsbad } \\
\text { NM }\end{array}$ & 500 & 4.61 & 4.31 & 11,060 & 9,700 & 1113 & 18.96 & 21,100 & 7 \\
\hline $\begin{array}{l}\mathrm{Ki} \text { illeen } \\
\mathrm{TX}\end{array}$ & $\begin{array}{l}\text { Carlsbad } \\
\text { NM }\end{array}$ & ATSF & 2.71 & 2.54 & 6,500 & 5,720 & 451 & 19.32 & 8,710 & $31 / 2$ \\
\hline $\begin{array}{l}\text { Colorado } \\
\text { Springs, Co }\end{array}$ & $\begin{array}{l}\text { Carlsbad } \\
\text { NM }\end{array}$ & ATSF & 3.61 & 3.43 & 8,660 & 7,720 & 650 & 19.32 & 12,560 & $41 / 2$ \\
\hline $\begin{array}{l}\text { Fayetteville } \\
\text { NC }\end{array}$ & $\begin{array}{l}\text { Carlsbad } \\
\text { NM }\end{array}$ & SOU & 5.88 & 5.52 & 14.110 & 12.420 & 1646 & 18.96 & 31,210 & 9 \\
\hline
\end{tabular}




\section{TABLE 9.2. (contd)}

\begin{tabular}{|c|c|c|c|c|c|c|c|c|c|c|}
\hline Origin & Destination & $\begin{array}{l}\text { Originating } \\
\text { Railroad(d) }\end{array}$ & $\begin{array}{r}\text { Frei } \\
\$ / 1 \\
\text { llass } 40 \\
\end{array}$ & $\begin{array}{l}\text { hit Rate, } \\
\frac{\text { o los }(a, b)}{\operatorname{class} 37-1 / 2}\end{array}$ & $\begin{array}{r}\text { Freigh } \\
\$ / \text { car } \\
\text { Class } 40 \\
\end{array}$ & $\begin{array}{l}\text { Charge, } \\
, 6, c) \\
\text { (lass } 33-1 / 2\end{array}$ & $\begin{array}{c}\text { Est imated } \\
\text { Tra in- } \\
\text { Miles } \\
\end{array}$ & $\begin{array}{c}\text { Special Train } \\
\text { Charges(e) } \\
\$ / \text { Mile }\end{array}$ & $\begin{array}{c}\text { Estimated } \\
\text { Special-Train } \\
\text { Charge, } \\
\$ / 1 \text {-Wayla,b) }\end{array}$ & $\begin{array}{c}\text { Estimated } \\
\text { Transit Time, } \\
\text { Days }\end{array}$ \\
\hline Columbus & $\begin{array}{l}\text { Carlsbad } \\
\text { NM }\end{array}$ & sou & 4.78 & 4. 30 & 11,470 & 9,680 & 1198 & 18.96 & 22,710 & $\begin{array}{ll}8 & 1 / 2\end{array}$ \\
\hline $\begin{array}{l}\text { Balt i imore, } \\
\text { MO }\end{array}$ & $\begin{array}{l}\text { Carlsbad } \\
\text { NM }\end{array}$ & BO & b.70 & 5.36 & 13,680 & 12,060 & 1863 & 20.74 & 38,640 & $81 / 2$ \\
\hline $\begin{array}{l}\text { Tacoma } \\
\text { Wh }\end{array}$ & $\begin{array}{l}\text { Carlsbad } \\
\text { MM }\end{array}$ & $B N$ & 8.35 & 7.83 & 20,040 & 17,620 & 2396 & 18.96 & 45,430 & $81 / 2$ \\
\hline $\begin{array}{l}\text { Fayet tevil le } \\
\text { NC }\end{array}$ & $\begin{array}{l}\text { Alpena } \\
\text { MI }\end{array}$ & $\mathrm{SCL}$ & 4.47 & 4.23 & 10,730 & 9,520 & 1276 & 18.96 & 24,190 & 9 \\
\hline $\begin{array}{l}\text { Col umbus } \\
\text { GA }\end{array}$ & $\begin{array}{l}\text { Alpena } \\
M 1\end{array}$ & sou & 4.57 & 4.28 & 10,970 & 9,630 & 1269 & 18.96 & 24,060 & 9 \\
\hline $\begin{array}{l}\text { Bait i imore } \\
\text { Mi) }\end{array}$ & $\begin{array}{l}\text { Alpena } \\
\mathrm{HI}\end{array}$ & BO & 3.92 & 3.68 & 9,410 & 8,280 & 952 & 20.74 & 19,740 & $51 / 2$ \\
\hline de dema & $\begin{array}{l}\text { Alpena } \\
\text { MI }\end{array}$ & $B N$ & 8.78 & 8.23 & 21.070 & 18,520 & 2679 & 18.96 & 50,790 & 9 \\
\hline
\end{tabular}

d) Listed freight rates and charges and special-train charges include all increases through $x$ - 330 . Special train charges are additive to freight charges.

b) Eastern railroads do not participate in these tariffs and require that the movement of nuclear waste material be conducted under contract. Thus, the listed freight rates and charges and special-train charges may not be applicable for the eastern railruads.

c) Assume: Class 40 minimum net weight $=240,000$ lbs; Class $371 / 2$ minimum net weight $=225,000$ lbs.
d) SCL-Seaboard Coastline; SOU-Southern; BO-Bdltimore \& Ohio; BN-Burlington Northern; ATSF-Atchison, Topeka and Santa Fe.

e) Weighted average for change or territury:

1) Western territory - $\$ 19.32 /$ train-mile

2) Southern territory - $\$ 18.96 /$ train-mile

f) 45 niles - Richiond to Baltimore - $\$ 2282.27$ (minimum charye)

412 miles - Barrwell to Richmond a \$18.96/train mile. 
Based on the history of railroad freight rates, Figure $9.3^{(34)}$ presents the price index for total railroad freight for a 11 commodities from January 1969 through January 1976; this information is presented here for future reference. During this $7 \mathrm{yr}$ period, the price index increased from 100 to 180 which is equivalent to an average annual increase of approximately $8.8 \%$. If we assume that freight rates continue to increase at this rate, then the 1983 freight rates are projected to be about double the 1976 rates.

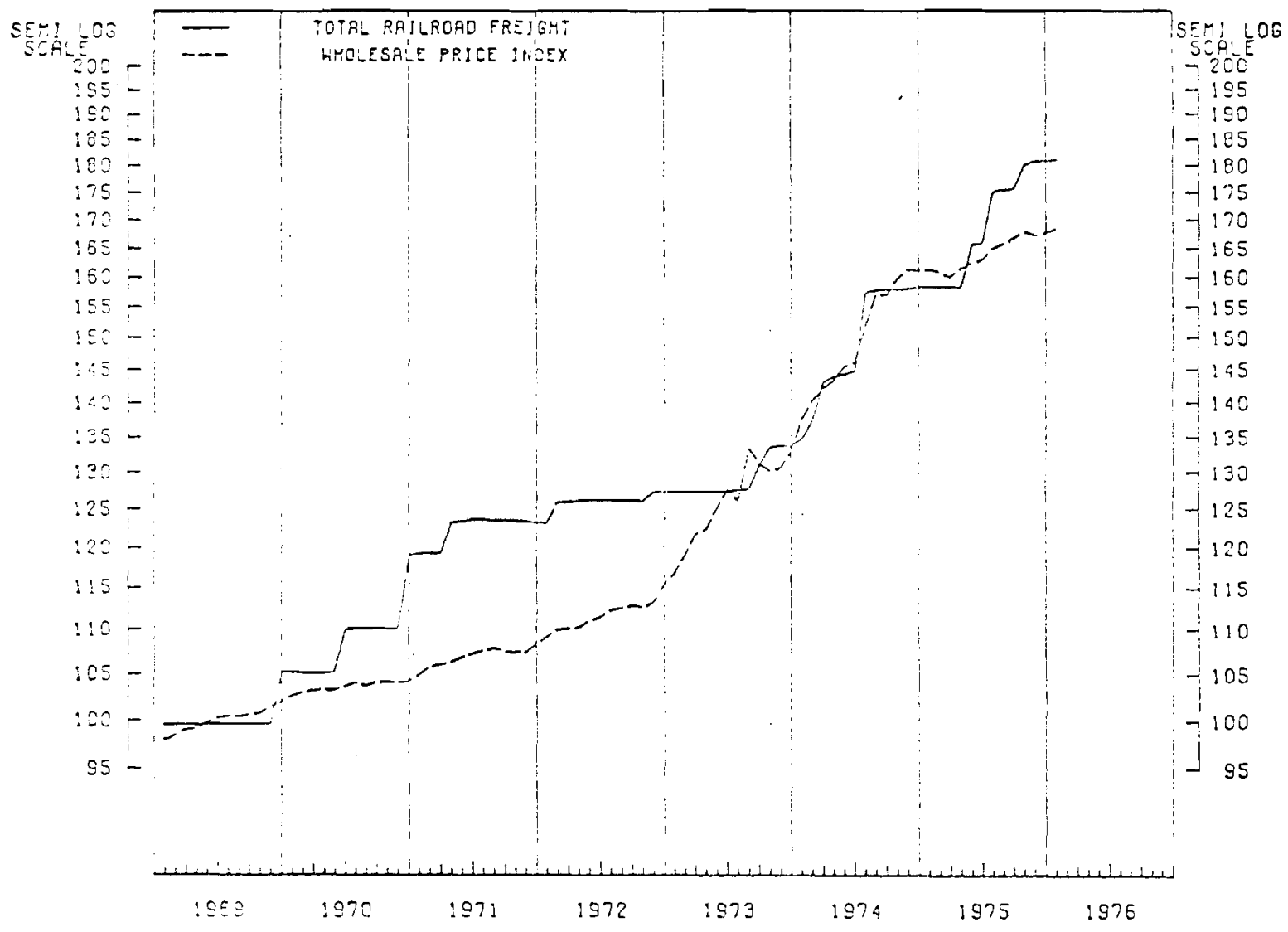

FIGURE 9.3. Price Indexes for Total Railroad Freight and Wholesale Price Index, A11 Commodities $(1969=100)$

For one Army facility operating at steady-state conditions in 1976, a resupply rate of 90 canisters/yr is required to maintain a 5-MW steam plant. The 2-yr-old waste is loaded and shipped to the Army facility at two canisters 
per cask. Forty-five cask trips are required to maintain the steady-state operation of the steam plant. Because of its lower radiation levels and heat output the 10-yr-old waste is shipped at six canisters per cask.

In this analysis we estimated the round trip costs of transporting the casks. The casks are assumed to be based at the fuel reprocessing plant. It is estimated by P. L. Peterson, PNL, that the casks have a $30 \mathrm{yr}$ life and a capital cost of $\$ 3 \mathrm{million} /$ cask. Due to the high capital cost of each cask, it is expected that the fuel reprocessor would strive for full utilization of the casks. Therefore, he will only own three or four casks. Thus, the Army can transport only three or four casks per train shipment. The high-level waste cask use charges are assumed to be similar to those for the NLI 10/24 spent fuel casks. Thus, the cask use charge supplied by $W$. V. Loscutoff, PNL, for casks owned by the fuel reprocessor used in this study is $\$ 2,500 /$ day/cask in 1976 dollars.

An alternative to the fuel reprocessor owning the casks is for the Army to own them. Based on a capital recovery factor of 0.125 and use of the casks for 365 days/yr, the cask use charge would be $\$ 1,030 /$ day. Both use charges $\$ 1030$ and $\$ 2500 /$ day will be used in the following analyses of transportation costs. In using $\$ 1030 /$ day, it is assumed that if the casks are not in use for supplying a particular Army steam plant, they can be used for transporting to disposal canisters not used by the Army or for supplying other Army plants.

Table 9.3 summarizes the transit times and distances of the various routes used in this analysis. It should be noted that of the 45 casks that arrive at the Army facility during the year, only 15 casks are used to transport the 10-yr-old waste from the Army facility to the disposal site. The empty casks are then shipped from the disposal site back to the fuel reprocessing plant. The remaining 30 casks are unloaded at the Army facility and are shipped directly back to the fuel reprocessing plant. It has been assumed that: 1) special trains are required for loaded and unloaded cask shipments, 2) the special train transit time is the same as regular train 
TABLE 9.3. Estimated Round Trip Transit Times and Distances of Representative Transportation Routes

\begin{tabular}{|c|c|c|c|}
\hline Route No. & Route & $\begin{array}{c}\text { Transit } \\
\text { Time } \\
\text { (Days) } \\
\end{array}$ & $\begin{array}{l}\text { Distance } \\
\text { (Miles) }\end{array}$ \\
\hline 1 & * Barnwell--1-1 & 26 & 2950 \\
\hline 2 & * Barniwel1-1 & 24 & 2316 \\
\hline 3 & 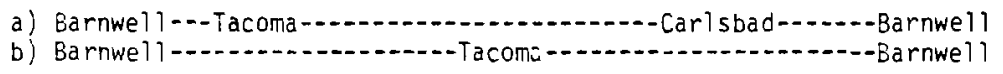 & $\begin{array}{l}34.5 \\
26\end{array}$ & $\begin{array}{l}7130 \\
6518\end{array}$ \\
\hline 4 & 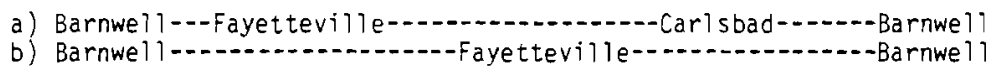 & $\begin{array}{c}26.5 \\
9\end{array}$ & $\begin{array}{r}3321 \\
400\end{array}$ \\
\hline 5 & 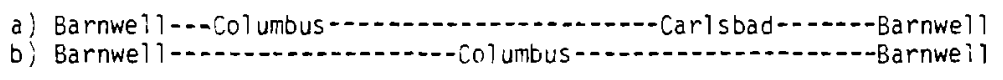 & $\begin{array}{l}27 \\
11\end{array}$ & $\begin{array}{r}3042 \\
738\end{array}$ \\
\hline 6 & 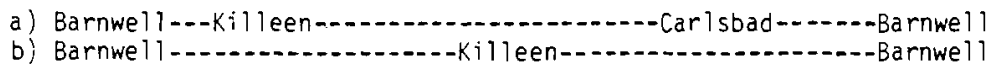 & $\begin{array}{l}26 \\
25\end{array}$ & $\begin{array}{l}3039 \\
2226\end{array}$ \\
\hline 7 & 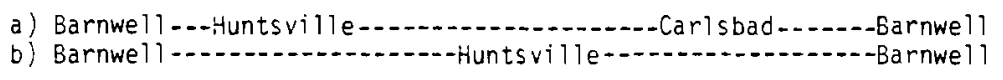 & $\begin{array}{l}29 \\
12\end{array}$ & $\begin{array}{r}3082 \\
988\end{array}$ \\
\hline 8 & 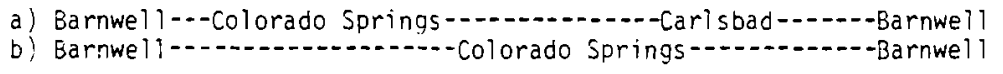 & $\begin{array}{l}31.5 \\
22\end{array}$ & $\begin{array}{l}3990 \\
3730\end{array}$ \\
\hline 9 & 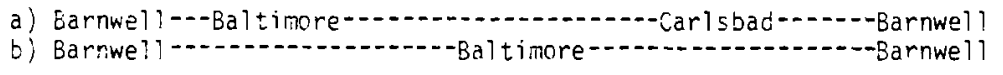 & 28 & $\begin{array}{r}3795 \\
914\end{array}$ \\
\hline 10 & 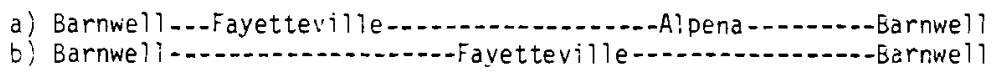 & $\begin{array}{c}31.5 \\
9\end{array}$ & $\begin{array}{r}2634 \\
400\end{array}$ \\
\hline$!$ & 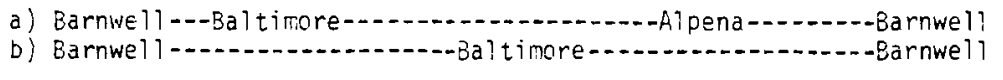 & $\begin{array}{l}28 \\
13\end{array}$ & $\begin{array}{r}2567 \\
914\end{array}$ \\
\hline 12 & 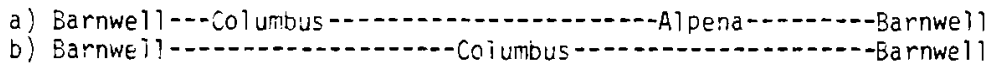 & $\begin{array}{l}29.5 \\
11\end{array}$ & $\begin{array}{r}2796 \\
738\end{array}$ \\
\hline 13 & 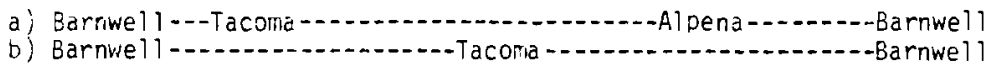 & $\begin{array}{l}37 \\
26\end{array}$ & $\begin{array}{l}7096 \\
6518\end{array}$ \\
\hline
\end{tabular}

* These routes are only shipping $10-y r$-old waste from the reprocessing plant.

transit time, and 3) the turnaround time for the casks is 3 days at each end of the shipment. Direct shipment costs are based on a 1500 MTHM/day fuel reprocessor producing 340 canisters/yr. To deliver this number of canisters to a disposal site in 1 yr, 4 casks would be required (4 casks/ train). The incremental cost (indirect minus direct) for the Army using the canisters divided by the fuel 011 required for a 5 -MW plant $\left(1.5 \times 10^{6}\right.$ ga1) gives the equivalent fuel oil price for canister transport; these are also included in Table 9.4. This assumes that the fuel reprocessor is willing to pay the Army the cost of direct canister shipment. For further 


\section{TABLE 9.4. Summary of Resupply Transportation Costs - Concepts 1.2 and 2.2 (5-MW Plant)}

Part A: Direct shipulent versus indirect shipment with West Coast disposal site.

\begin{tabular}{|c|c|c|c|}
\hline Route No & $\begin{array}{l}\text { No. of } \\
\text { Cask Used } \\
\text { Pershipment }\end{array}$ & $\begin{array}{r}\text { No. of } S \\
\text { Route } \\
\text { Req }\end{array}$ & 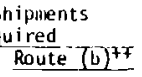 \\
\hline (0) 1 (Carlsbad) & 4 & $4^{*}$ & \\
\hline (I) 3 (Tacoind) & 4 & 4 & 8 \\
\hline (I) 4 (fayetteville) & 3 & 5 & 10 \\
\hline (1) 5 (Colunibus) & 3 & 5 & 10 \\
\hline (1) 6 (killeen) & 3 & 5 & 10 \\
\hline (1) 7 (Huntsville) & 3 & 5 & 10 \\
\hline (1) 8 (Colurado Springs & gs) & 5 & 10 \\
\hline (I) 9 (Baltinore) & 3 & 5 & 10 \\
\hline
\end{tabular}

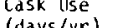
Regular Freight Special Train

Fuel Reprocessor Owns Casks Cask Use Total costs Fuel oil Price $\frac{(d a y s / y r)}{\text { Route }}(b)$

$\begin{array}{cc}369.000 & \text { (\$) } \\ 223,160\end{array}$

$\begin{array}{lr}330^{\star} & 369.000 \\ 139 & 208\end{array}$

223.160 Costs $(\$) \quad(\$)$ costs Fuel $(\$ /$ gal $)$

$325,000 \quad 1,417,760$

$3,460,000 \quad 7,357,560$

$390,650 \quad 1,672,500 \quad 2,776,400$

$\begin{array}{rrrrrr}133 & 90 & 713,250 & 390,650 & 1,672,500 & 2,776,400 \\ 135 & 110 & 721,650 & 428,400 & 1.837,500 & 2,987,550 \\ 130 & 250 & 1,038,700 & 710,900 & 2,850,000 & 4,619,600\end{array}$

$130 \quad 250 \quad 1,058,700$

710,900

$2.050,000 \quad 4,619,600$

816,9019

$\begin{array}{lll}.036,650 & 2,835,000 & 5,201,450\end{array}$

$585,300 \quad 2,025,000 \quad 3,532,350$

922.050

$177,200 \quad 750.000 \quad 1,239,650$

$326,450 \quad 1,860,000 \quad 2,822,600$

$461,700 \quad 2,025,000 \quad 3,318,300$

$406,050 \quad 1,935,000 \quad 3,028,300$

$1,541,460 \quad 3,560,000 \quad 7,444,040$
636,150
1331.600

6937,150

2. 342.080

(S/gal)

3.96

3.05

2.13

1. 24

1.41

-
1.06
1.39
1.19
4.14
Araly Owns Casks Equivatent Cask use Total Fuel Oil Pric

$1,425,520 \quad 4,040,080$ $689,070 \quad 1,792.170$ $757.050 \quad 1,907.100$ $1,174,200 \quad 2,943,800$ $818,850 \quad 2,115,350$ $1,168,020 \quad 3,534,470$ $834,300 \quad 2,341,650$

$t=$ Route (a) indicates the casks that are shipped from the Army facility to the disposal site and then back to the Reprocessing Plant. $\because$ = Route (b) indicates the casks that are shipped from the Artuy facility directly back to the Reprocessing Plant.

Route $(a)$ and route $(b)$ do not apply.

$D=$ Direct shipment.
$1=$ Indirect shipment. 
explanation of equivalent fuel oil price and fuel reprocessor payments to the Army see Section 10.5 "Overall Economics". Based on the assumptions above and the data in Table 9.2 and 9.3, we can estimate the total round trip cost of the casks for each route. The total resupply transportation costs for the various routes are presented in Table 9.4.

The major cost component of the transportation costs is the cask use costs (which led to considering Army cask ownership above). One additional method to reduce cask use costs is to lower the number of cask use days. With the assumption that the special train transit time is the same as the regular train transit time (which is probably somewhat optimistic), it is not probable that the casks use days will be lower than the values estimated here.

Understandably, the lowest transportation cost, \$0.91/gal fuel oil (Fuel Reprocessor's cask), is for a steam plant located at Fayetteville, North Carolina which is only 200 miles from Barnwell, South Carclina. The next grouping of costs are for route $5,7,10$, and 12 and lie between $\$ 1.05$ to $\$ 1.25 /$ gal fuel oil (Fuel Reprocessor's casks). Route 12 (steam plant at Columbus, Georgia and disposal site at Alpena, Michigan) at $\$ 1.19 / 9 a 1$ will be used to represent this cost range in further analysis and Route 4 (Fayetteville and Carlsbad) will be used to represent the lowest transportation cost. The other locations such as Tacoma, Washington; Kileen, Texas; and Colorado Springs, Colorado have transportation costs over $\$ 2.00 /$ gal for Fuel Reprocessor-owned casks and over $\$ 1.00 /$ gal for Army-owned casks; therefore, these locations will not be considered further.

Table 9.5 presents the total resupply transportation costs for all the concepts. Since the storage times in Concepts $1.4,2.5,2.4$, and 2.6 are greater than $10 \mathrm{yr}$, the direct transportation costs have been taken to be the same as in Concepts 1.2 and 2.2; the former concepts assume that the Army can store high-level waste more than $10 \mathrm{yr}$ since it is essentially a Federal repository where the fuel reprocessor cannot. For example, the storage time in Concept 1.4 is $27 \mathrm{yr}$ with a canister diameter of $16 \mathrm{in}$, calcine-Al matrix waste form, and a final head load of $5 \mathrm{~kW}$. A fuel reprocesor is limited by law to $10 \mathrm{yr}$ storage (see Part 50, Appendix F Reference 7); 


\section{TABLE 9.5. Annual Resupply Transportation Costs - All Concepts}

\begin{tabular}{|c|c|c|c|c|c|}
\hline \multirow[b]{2}{*}{ Concept No. } & \multirow[b]{2}{*}{ Route No. } & \multicolumn{2}{|c|}{ Fuel Reprocessor Casks (a) } & \multicolumn{2}{|c|}{ Army Casks (a) } \\
\hline & & $\begin{array}{c}\text { Total Cost } \\
(5 \mathrm{MW} \text { Plant) } \\
\$ \times 10^{6} \\
\end{array}$ & $\begin{array}{c}\text { Equivalent Fye } \\
0 \text { il Price, } \\
\$ / \text { gal } \\
\end{array}$ & $\begin{array}{c}\text { Total Cost } \\
(5 \mathrm{MW} \mathrm{Plant)} \\
\$ \times 10^{6} \\
\end{array}$ & $\begin{array}{c}\text { Equivalent Fye }) \\
0 \text { il Price, } \\
\text { S/gal } \\
\end{array}$ \\
\hline $1.1,2.1$ & $\begin{aligned} & 1 \text { (Carlsbad) } \\
& 4 \text { (Fayetteville) } \\
& 2 \text { (Alpena) } \\
& 12 \text { (Columbus) }\end{aligned}$ & $\begin{array}{l}2.09 \\
2.99 \\
1.77 \\
3.31\end{array}$ & $\begin{array}{l}0 . \overline{60} \\
1 . \overline{03}\end{array}$ & $\begin{array}{l}2 . \overline{18} \\
-\overline{32}\end{array}$ & $\begin{array}{l}0 . \overline{-} \\
\overline{-} \\
0.37\end{array}$ \\
\hline $1.2,2.2$ & $\begin{array}{r}1 \\
4 \\
2 \\
12\end{array}$ & $\begin{array}{l}1.42 \\
2.78 \\
1.24 \\
3.03\end{array}$ & $\begin{array}{c}- \\
0.91 \\
- \\
1.19\end{array}$ & $\begin{array}{l}-\overline{79} \\
1 . \overline{89}\end{array}$ & $\begin{array}{l}0 . \overline{25} \\
0 . \overline{43}\end{array}$ \\
\hline $1.3,2.3$ & $\begin{array}{r}1 \\
4 \\
2 \\
12\end{array}$ & $\begin{array}{l}0.96 \\
1.93 \\
0.86 \\
2.21\end{array}$ & $\begin{array}{l}- \\
0.65 \\
- \\
0.90\end{array}$ & $\begin{array}{l}1 . \overline{41} \\
- \\
1.57\end{array}$ & $\begin{array}{l}0 . \overline{30} \\
\overline{-} \\
0 . \overline{4}\end{array}$ \\
\hline $1.4,2.5$ & $\begin{array}{r}1 \\
4 \\
2 \\
12\end{array}$ & $\begin{array}{l}1.42 \\
1.33 \\
1.24 \\
1.49\end{array}$ & $\begin{array}{c}-0.06 \\
\overline{-} \\
0.17\end{array}$ & $\begin{array}{c}-\overline{98} \\
- \\
1.14\end{array}$ & $\begin{array}{l}-0 . \overline{29} \\
- \\
-0.07\end{array}$ \\
\hline $1.5,2.7$ & $\begin{array}{r}1 \\
4 \\
2 \\
12\end{array}$ & $\begin{array}{l}0.75 \\
1.79 \\
0.66 \\
1.89\end{array}$ & $\begin{array}{c}\overline{-} \\
0.69 \\
-\overline{82}\end{array}$ & $\begin{array}{l}-5 \\
1.34 \\
1.35\end{array}$ & $\begin{array}{l}-\overline{-} \\
0.39 \\
-\overline{46}\end{array}$ \\
\hline $1.6,2.8$ & $\begin{array}{r}1 \\
4 \\
2 \\
12\end{array}$ & $\begin{array}{l}0.75 \\
1.77 \\
0.66 \\
2.06\end{array}$ & $\begin{array}{c}-\overline{68} \\
-\overline{9} \\
0.93\end{array}$ & $\begin{array}{l}1 . \overline{28} \\
1.47\end{array}$ & $\begin{array}{l}- \\
0.36 \\
-\overline{54}\end{array}$ \\
\hline 2.4 & $\begin{array}{r}1 \\
4 \\
2 \\
12\end{array}$ & $\begin{array}{l}1.42 \\
1.53 \\
1.24 \\
1.69\end{array}$ & $\begin{array}{c}-\overline{07} \\
- \\
0.30\end{array}$ & $\begin{array}{l}\overline{19} \\
\overline{-} \\
1.29\end{array}$ & $\begin{array}{c}-0 . \overline{15} \\
-\overline{03}\end{array}$ \\
\hline 2.6 & $\begin{array}{r}1 \\
4 \\
2 \\
12\end{array}$ & $\begin{array}{l}1.42 \\
1.05 \\
1.24 \\
1.14\end{array}$ & $\begin{array}{c}- \\
-0.25 \\
-0.07\end{array}$ & $\begin{array}{l}0 . \overline{82} \\
0 . \overline{87}\end{array}$ & $\begin{array}{c}-\overline{40} \\
-0 . \overline{25}\end{array}$ \\
\hline
\end{tabular}

(a) Maximum number of canisters per cask are 20,12,9,6, and 4 for $8,10,12,16$, and 20 in. diameter canisters, respectively.

(b) Equivalent fuel oil price includes credit to the Army from the fuel reprocessor for not incurring the costs of shipping the canisters directly to the disposal site (Routes 1 and 2) if the Amy uses the canisters. In some cases this credit is larger than the Army cost (Routes 4 and 12) resulting in a negative equivalent fuel 0 il price.

direct shipment from the fuel reprocessor site to a disposal site after 27 yr of storage is not possible according to current Federal regulations. Therefore, direct transportation costs are based on Concept 1.2 and 2.2 which have a canister storage time less than $10 \mathrm{yr}$. Due to the longer decay time for 27 yr storage the direct transportation charges from Concept 1.2 and 2.2 are more than the indirect charges in some cases, and the transportation costs are negative. Similar reasoning was used to estimate the potential 
credit to the Army for eliminating the fuel reprocessor storage facility (see Section 10.4). It might appear that using the transportation costs of Concepts 1.2 and 2.2 for direct shipment will be a major advantage to Concepts $1.4,2.5,2.4$, and 2.6 , but the reduced credit for storage (the fuel reprocessor's capital investment for a storage facility for 10-yr storage is much less than for 27-yr storage) tends to balance out the transportation cost advantage. Similar reasoning was used to estimate the potential credit to the Army for eliminating fuel reprocessor storage requirements. Thus, in these cases of greater than $10 \mathrm{yr}$ storage, the difference between indirect and direct shipment is negative or a credit to the Army.

Based on Routes 4 and 12, the transport costs for the initial canister loading of a new Army steam plant will be calculated using Concepts 1.2 and 2.2 as an example. There exist several alternatives dependent on the age of the solidified waste: 1) the canisters initially available all contain 2-yr-old waste, and 2) the canisters are available in the ages between 10 and $2 \mathrm{yr}$ so the initial loading results in the normal operating waste age distribution for the Army steam plants. The actual situation would probably be between these two alternatives unless the Army plant is not available to accept canisters of 2-yr waste age. This latter case would require a fuel reprocessor to have some canister storage capacity (probably not as large as required for $8 \mathrm{yr}$ storage) which would decrease the Army's credit for storage. In assuming Army storage of all canisters, the actual waste age available may not be the ideal case; there may be more canisters containing waste of 9-yr age than the 90 canisters needed for a 5-MW plant (Concept 1.2 and 2.2). Thus, the steam plant would run at an output lower than $5 \mathrm{MW}$ for the first few years reducing the initial savings which could probably be recovered over the life of the plant. However, alternatives 2 will be used as a basis for the initial loading costs.

The total number of cask deliveries needed to supply 720 canisters containing waste ages between 2 and 9 yr $(90-2$ yr old, $90-3$ yr old ...90 - 9 yr old) is 176 as shown in Table 9.6. With 3 casks/train, 
TABLE 9.6. Initial Loading Costs - Concepts 1.2 and 2.2 (1976 \$)

\begin{tabular}{|c|c|c|c|}
\hline $\begin{array}{c}\text { Waste Age, } \\
\text { yr }\end{array}$ & $\mathrm{kW} /$ Canister & $\operatorname{ers} / \operatorname{Cask}^{(a)}$ & $\begin{array}{c}\text { Number } \\
\text { of Casks }\end{array}$ \\
\hline 2 & 25.3 & 2 & 45 \\
\hline 3 & 16.0 & 3 & 30 \\
\hline 4 & 11.2 & 4 & 23 \\
\hline 5 & 8.6 & 5 & 18 \\
\hline 6 & 7.3 & 6 & 15 \\
\hline 7 & 6.3 & 6 & 15 \\
\hline 8 & 5.7 & 6 & 15 \\
\hline \multirow[t]{2}{*}{9} & 5.3 & 6 & $\underline{15}$ \\
\hline & & Total & 176 \\
\hline \multicolumn{4}{|c|}{ Special Trains $=176$ casks $/(3$ cask $/$ train $)=59$} \\
\hline \multicolumn{4}{|c|}{ Route 4 (Barnwell to Fayetteville): } \\
\hline \multicolumn{4}{|c|}{ Freight Cost $=176 \times(\$ 4,660+\$ 4,070)=\$ 1,536,480$} \\
\hline \multicolumn{4}{|c|}{ Special Train Charge $=59 \times 2 \times \$ 3,790=\$ 447,220$} \\
\hline \multicolumn{2}{|c|}{ Cask Use Charge $=176 \times 6 \times \$ 2,500$} & $=\$ 2,640,000$ & \\
\hline \multicolumn{2}{|c|}{ Tota 1} & $=\$ 4,623,700$ & \\
\hline Annual 0 & st $(C R F=0.125)$ & $=\$ 577,960$ & \\
\hline $\begin{array}{l}\text { Equivale } \\
\text { (Fuel }\end{array}$ & $\begin{array}{l}\text { nt Fuei Dil Price, } \$ 1 / g a l \\
\text { Reprocessor Casks) }\end{array}$ & $=0.39$ & \\
\hline $\begin{array}{l}\text { Equivale } \\
\text { (Army }\end{array}$ & $\begin{array}{l}\text { nt Fuel Oil Price } \$ / g a l \\
\text { (asks) }\end{array}$ & $=0.26$ & \\
\hline
\end{tabular}

59 special trains would be required. Using the information in Tables 9.2 and 9.3, the costs for initial delivery can be calculated as shown in Table 9.6 for Route 4 . It is assumed initial delivery costs can be treated as a capital investment.

Table 9.7 summarizes the canister transportation costs in equivalent fuel oil price for all the concepts for initial loading. These are the same for 5-, 10-, and 20-MW steam plants since the number of canisters required and the fuel oil saved for 10- and 20-MW plants are multiples of the 5-MW plant.

These transportation costs will be used to study the overall economics of Army steam plants which is presented in the next section. 
TABLE 9.7. Initial Loading Transportation Costs All Concepts, Equivalent Fuel 011 Price, \$/gal (1976\$)

\begin{tabular}{|c|c|c|c|c|c|}
\hline \multirow[b]{2}{*}{ Waste Form } & \multirow{2}{*}{$\begin{array}{l}\text { Concept } \\
\text { Number }\end{array}$} & \multicolumn{2}{|c|}{ Fuel Reprocessor Casks } & \multicolumn{2}{|c|}{ Army Casks } \\
\hline & & Fayetteville & Columbus & Fayetteville & Columbus \\
\hline Borosilicate & $1.1,2.1$ & 0.45 & 0.54 & 0.28 & 0.34 \\
\hline Borosilicate & $1.2,2.2$ & 0.39 & 0.53 & 0.26 & 0.33 \\
\hline Calcine-Al & $1.3,2.3$ & 0.34 & 0.47 & 0.23 & 0.30 \\
\hline Calcine-Al & $1.4,2.5$ & 0.35 & 0.53 & 0.22 & 0.33 \\
\hline Calcine & $1.5: 2.7$ & 0.33 & 0.46 & 0.22 & 0.29 \\
\hline Calcine & $1.6,2.8$ & 0.30 & 0.43 & 0.21 & 0.27 \\
\hline Borosilicate & 2.4 & 0.35 & 0.53 & 0.22 & 0.33 \\
\hline Calcine-Al & 2.6 & 0.30 & 0.48 & 0.22 & 0.31 \\
\hline
\end{tabular}




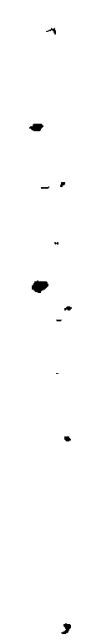

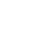


10.0 ECONOMICS OF ARMY STEAM PLANTS 


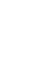

-

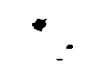




\subsection{ECONOMICS OF ARMY STEAM PLANTS}

The economics of Army steam plants will be divided into five parts: 1) capital investment, 2) operating costs, 3) fuel oil boiler capital and operating costs, 4) fuel reprocessor savings - Army credit for canister storage, and 5) overall economics. The costs for transportation of canisters has been treated in the previous section. Items 3 and 4 recognize two factors; a steam plant fueled with canisters would eliminate the costs for a fuel oil boiler and the use of the canisters by the Army would ideally eliminate the costs to the fuel reprocessor of storing the canisters. The costs are developed for 5-, 10-, and 20-MW size plants.

\subsection{STEAM PLANT CAPITAL COSTS}

Cost estimates for steam plants were based on the work of Kaiser Engineers, Oakland, CA and the Atlantic Richfield Hanford Company (ARHCO) on the RSSF water basin concepts. $(4,5)$ For example, their price for concrete and the stainless steel basin liner was used directly. The costs of certain items (such as curb anchors and stainless steel channels) were estimated by factoring them with the ratio of the surface areas of the RSSF and the steam plants requiring stainless steel liners. Once the capital cost was found based on Kaiser Engineers' unit costs, the costs were escalated to 1976 \$ by using Chemical Engineers Plant cost Index. ${ }^{(35)}$ As examples, the details of the cost estimates for Concepts 1.2 and 2.2 are contained in Appendix C.

The cost for the cooling system, Receiving Facility, emergency generators, and handling equipment will be identical for both concepts 1 and 2 . Table 10.1 reports these costs for the Water Basin Receiving Facility and Table 10.2 reports the costs for the Hot Cell Receiving Facility. The 1.44 factor for the electrical, pipework, etc. was calculated from the more detailed RSSF design.

The capital costs for the Boiler Facility will be developed for each case: six cases for Concept 1 and eight cases for Concept 2. The costs for concrete, stainless steel, and other typical items are also based on 
TABLE 10.1. Capital Costs of the Water Basin Receiving Facility (1976\$)

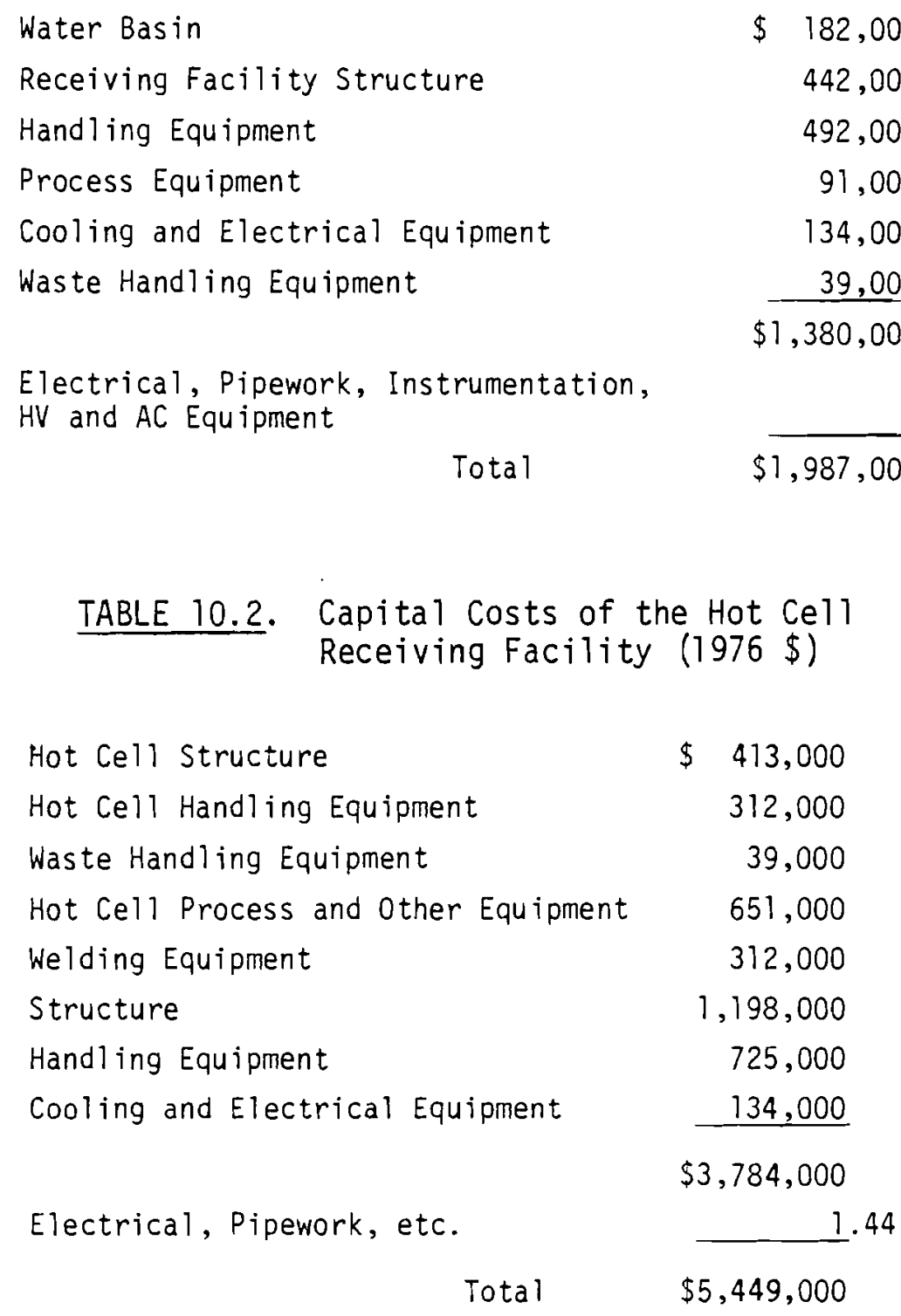

the RSSF work. For special equipment, such as the boilers in Concept 1, a manufacturer, Alaskan Copper Works, was contacted for stainless steel costs and costs for carbon steel boilers were based on those results. The cost estimate of the large pressure heads was supplied by Lukens Steel co. For the details of the design and cost estimates on these special equipment items 
see Appendix D. Also included in this Appendix is information on the design and cost of the secondary heat exchangers of Concept 2.

Costs for either concept will be similar for sitework, yardwork, exhaust fan and filter house, and communications and alarm systems; these costs are presented in Table 10.3. Included in sitework are site clearing and grading, yard lighting, roads and parking, fencing, drainage, plant railroad, and soil stabilization and sterilization. Yardwork includes raw water and fire main piping, Class I emergency water supply, sanitary sewer, waste water, electrical substation, and electrical distribution. For simplification, the sitework costs have been obtained by ratioing the estimated acreage for the steam plant ( 2 acres) to the RSSF water basin concept acreage (15 acres). The estimate of yardwork also takes into account the smaller plant size. Also, some items such as a 250,000 gal water storage tank and two Class I wells are considered to be identical requirements. However, the waste water pond was reduced from $11,200 \mathrm{yd}^{3}$ excavation in the RSSF design to $3000 \mathrm{yd}^{3}$ for the Army steam plant. Also, the steam plant was assumed to require only one electrical substation where the RSSF design required three. Pipework was reduced in length due to the smaller site size, i.e., the water main ( 8 in. diameter) length was reduced from $2300 \mathrm{ft}$ to $1000 \mathrm{ft}$; the latter length was assumed to include pipe to supply water to the site. The exhaust fan and filter house was reduced by $50 \%$ in size and capacity since both the Boiler Facility and Receiving Facility (water basin transfer) are about 1/2 the volumes of the RSSF water basin concept facilities. Communications and alarm capabilities were also reduced by $50 \%$. An exception was the stack and monitor room which remained the same size.

TABLE 10.3. Capital Cost for Sitework, Yardwork, Exhaust Fan and Filter House, and Communications and Alarm 5-MW Plant (1976 \$)

$\begin{array}{lr}\text { Sitework } & \$ 81,000 \\ \text { Yardwork } & 535,000 \\ \text { Exhaust Fan and Filter House } & 208,000 \\ \text { Communications and Alarm } & \frac{118,000}{10 t a 1} \\ & \$ 942,000\end{array}$


The total capital costs and annual capital costs for Concepts 1 and 2 are summarized in Table 10.4 for 5-, 10-, and 20-MW plants. The annual capital costs were obtained by multiplying the total capital cost by an annual capital recovery factor. (35) The capital recovery factor, $\alpha=0.125$, is the sum of two parts: $\alpha_{1}$ which equals 0.086 (a 7\% loan for $25 \mathrm{yr}$ ) and $\alpha_{2}$ which equals 0.039 (for maintenance).

The cost estimates in Table 10.4 for the 10-ilW and 20-MW plants were obtained by multiplying the 5-MW plant capital costs (excluding that for the Receiving Facility) by 2 and 4 , respectively since the major costs for the Storage Facilities are dependent on the plant size or number of canisters stored, i.e., concrete, boilers, and stainless steel liner. The plant size is directly proportional to steam plant thermal output. This is somewhat simplified since the cost for the building could be reduced by elimination of walls and piping costs could be less. However, the major costs will be directly proportional to thermal output. Also, for a 20-MW plant the Receiver Facility may need to be expanded since the canister delivery rate will be four times as large. The effect of expanding the Receiver Facility will be considered in Section 10.5. Other costs such as sitework and yardwork were also scaled by the ratio of thermal output. Details of capital costs for the concepts which employ 16 in. diameter canisters filled with borosilicate glass and eight fins are presented in Table 10.5. These canisters are used as an example because they are considered to be the most likely canister to be produced initially.

The differences in capital costs for the various waste forms and canister diameters for a particular concept with the same material used for special equipment are not extreme. As expected, substantial savings are realized when the special equipment of Concept 1 (boilers and shield tanks) are made from carbon stee1. However, Concept 2 apparently has the lowest capital costs with the present design. It also has the advantages of double barriers which can be monitored as previously discussed in Section 8.1. Concept 1 could use a secondary heat transfer loop; the additional heat exchanger costs would be minimal, but the higher boiler pressure (thicker 
TABLE 10.4. Summary of Capital Costs, $\$ \times 10^{6}$ (1976\$)

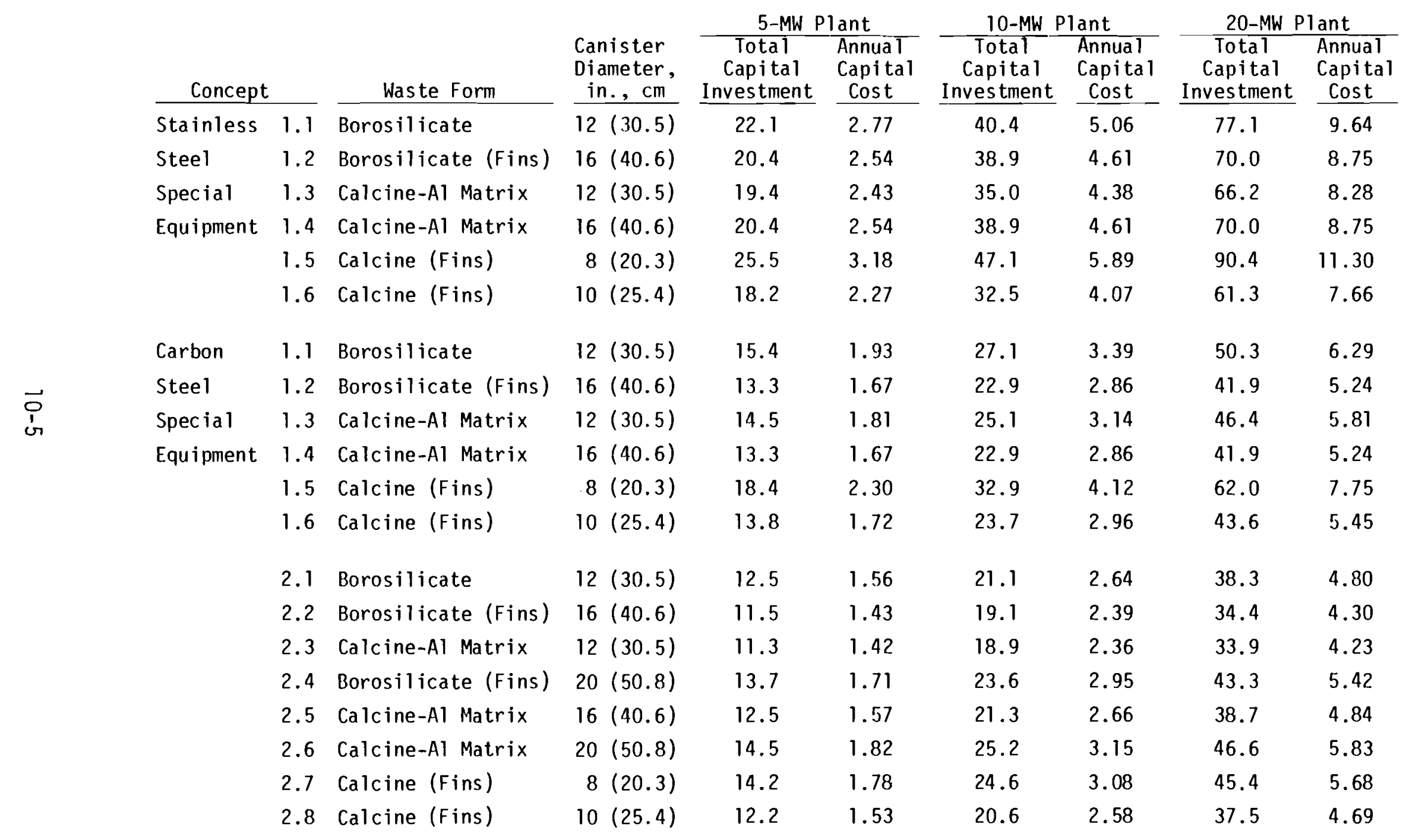


TABLE 10.5. Capita1 Costs for Concepts Using Canisters 16 in. Diameter, Borosilicate Glass with Fins, 5-MW Plant, $\$ \times 10^{3}$ (1976\$)

\begin{tabular}{|c|c|c|c|}
\hline & $\begin{array}{c}\text { Concept } \\
1.2, \\
\text { Stainless } \\
\text { Steel } \\
\end{array}$ & $\begin{array}{c}\text { Concept } \\
1.2, \\
\text { Carbon } \\
\text { Steel } \\
\end{array}$ & $\begin{array}{l}\text { Concept } \\
2.2 \\
\end{array}$ \\
\hline $\begin{array}{l}\text { Receiving Facility } \\
\text { (Water Basin) }\end{array}$ & 1,987 & 1,987 & 1,987 \\
\hline Boiler Facility & 4,284 & 4,284 & 2,688 \\
\hline Special Equipment & 4,642 & 990 & 451 \\
\hline $\begin{array}{c}\text { Exhaust Fan and } \\
\text { Filter House }\end{array}$ & 208 & 208 & 208 \\
\hline Communications and Alarm & 118 & 118 & 118 \\
\hline Sitework & 81 & 81 & 81 \\
\hline Yardwork & 535 & 535 & 535 \\
\hline Total Direct Costs & 10,601 & 6,949 & 5,968 \\
\hline Indirect Costs, $20 \%$ & 2,120 & 1,390 & $\underline{1,194}$ \\
\hline Total Construction Costs & 12,721 & 8,339 & 7,162 \\
\hline Design and Engineering, $30 \%$ & 3,816 & 2,502 & 2,148 \\
\hline Design Uncertainties, $20 \%$ & 2,544 & 1,668 & 1,432 \\
\hline Contingency, $10 \%$ & 1,272 & 834 & 716 \\
\hline Total Capital Cost & 20,354 & 13,342 & 11,458 \\
\hline
\end{tabular}

wa11s) would increase boiler costs. Concept 2 capital costs assumed no additional costs for making the boiler cell stainless steel liners adequate as pressure vessel walls and no special flanges for pressure head removal. Thus, the capital costs for Concept 2 may be low. These costs must be further detailed if plans proceed for Army use of these canisters in steam plants.

\subsection{OPERATING COSTS}

The major costs for operating are labor, electricity, water, and nuclear waste disposa1. The estimated annual labor costs for a 5-MW plant are presented in Table 10.6. Some of the craft services, as noted in Table 10.6, are borrowed from other facilities. The labor cost for personnel to unload casks and reload boilers with canisters has not been included. These tasks could be hancled by the operators working some overtime, since canisters would not be transferred/processed every day. The labor costs for larger plants has 
TABLE 10.6. Labor Costs, 5-MW Plant (1976\$)

\begin{tabular}{lc} 
Operations: & \\
\hline (7 days/week - 4 Shifts tota 1$)$ & Total $\$ \mathrm{~K} / \mathrm{yr}$ \\
Shift Supervisor $(\$ 25 \mathrm{~K} / \mathrm{yr})$ & 100 \\
Operating Engineer $(\$ 20 \mathrm{~K} / \mathrm{yr})$ & 80 \\
2-Operators $(\$ 15 \mathrm{~K} / \mathrm{yr})$ & 120 \\
Radiation Monitor $(\$ 15 / \mathrm{yr})$ & $-\frac{60}{360}$
\end{tabular}

Craft Services:

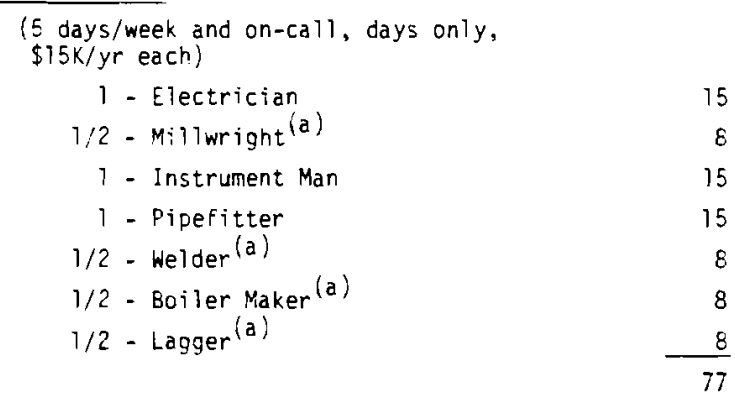

Management:

\begin{tabular}{lr}
\hline (5 days/week-days on 7 ) & \\
Plant Mariager & 30 \\
Chief Engineer & 25 \\
QA-QC Inspector & 20 \\
Craft Foreman & 20 \\
Secretary & $\frac{7}{102}$ \\
& 1,078
\end{tabular}

(a) Borrowed from other installation

been scaled using the 0.25 exponential factor $(35)$ on operations and craft services; management costs have been assumed to be the same as for the 5-MW plant. Thus, the annual labor costs for a 10-MW and 20-MW plant are $\$ 1,248 \mathrm{~K}$ and $\$ 1,444 \mathrm{~K}$, respectively.

The electrical requirements for the Army plants were estimated by suming up the requirements for pumps, instrumentation, lighting, cranes, etc., for the present design. Information from the RSSF design was used as a basis for specific items. It was assumed that pumps and cranes would run $25 \%$ of the time. The Receiver Facility electrical requirements were taken to be the same for each size plant. The Storage Facility requirements were obtained for the 10- and 20-MW plants by multiplying the 5-MW plants value by the ratio of thermal output ( 2 and 4 , respectively). The nuclear waste and raw 
water requirements were obtained by scaling the requirements for the RSSF water basin concept which were given as the year 2010 requirements for storing 75,014 canisters. ${ }^{(4)}$ As mentioned in the 1 and requirements, the eight basin size RSSF for the year 1990, storing 4000 canisters, is about twice the size of a 5-MW plant. Thus, the requirements were estimated by using a scaling factor of plant size to the 0.6 exponent which equals $0.114=(4000 / 75$, $014 \times 1 / 2)^{0.6}$. This scaling factor was used rather than the direct ratio of plant size because the Receiver Facilities (which would consume a major portion of these utilities) are assumed to be the same for each plant size. The 10- and 20-MW plants were scaled to the 5-MW plant by factors of $2^{0.6}$ and $4^{0.6}$, respectively. On these bases, utilities for the 5-, 10- and 20-MW steam plants and the associated costs were estimated (Table 10.7). The electric rate used was $\$ 0.025 / \mathrm{kW}-\mathrm{hr}$ which can depend significantly on location. Raw water and nuclear waste rates were escalated from ARH-2888 Rev. (4) Table 10.7 also summarizes the yearly total operating costs for the $5-, 10-$ and 20-MW steam plants.

\section{TABLE 10.7. Utilities and Total Annual Operating Costs} for Army Steam Plants (1976\$)

\begin{tabular}{|c|c|c|c|c|c|c|c|}
\hline \multirow[b]{2}{*}{ Service } & \multirow[b]{2}{*}{ Unit Cost } & \multicolumn{2}{|c|}{$5 \mathrm{MW}$} & \multicolumn{2}{|c|}{$10 \mathrm{MW}$} & \multicolumn{2}{|c|}{$20 \mathrm{MW}$} \\
\hline & & Quantity & Cost, $\$ \times 10^{3}$ & Quantity & Cost, $\$ \times 10^{3}$ & Quantity & Cost, $\$ \times 10^{3}$ \\
\hline Electricity & $\$ 0.025 / \mathrm{kW}-\mathrm{hr}$ & $2.6 \times 10^{6}$ & 65 & $4.5 \times 10^{6}$ & 113 & $8.1 \times 10^{6}$ & 203 \\
\hline Raw Water & $\$ 64 / 10^{6}$ gal & 170 & 11 & 250 & 16 & 390 & 25 \\
\hline Nuclear Waste & $56 / \mathrm{ft}^{3}$ & 2600 & 16 & 4000 & 24 & 6000 & 36 \\
\hline Total & & & 92 & & 153 & & 264 \\
\hline Labor & & & 1,078 & & 1,248 & & 1,444 \\
\hline Total Operating & & & 1,170 & & 1,401 & & 1,708 \\
\hline
\end{tabular}

10.3 FUEL OIL BOILER CAPITAL AND OPERATING COSTS

An Army steam plant fueled with HLW canisters could replace conventional steam generating systems, which would result in a cost advantage to the HLW plant. This savings will be estimated based on a fuel oil boiler.

A 5-MW boiler is estimated to cost $\$ 60,000$ installed plus $\$ 10,000$ for fuel tank and pump. ${ }^{(35)}$ It wi11 be assumed that for a 10- and 20-MW plant the costs would be $\$ 140,000$ and $\$ 280,000$, respectively. Operating labor, annual capital cost, and the total annual cost excluding fuel are summarized 
in Table 10.8. The fuel oil requirements for 5-, 10-, and 20-MW will be about $1.5 \times 10^{6}, 3.0 \times 10^{6}$, and $6.0 \times 10^{6} \mathrm{gal} / \mathrm{yr}$ based on a fuel oil heat value of $120,000 \mathrm{Btu} / \mathrm{gal}$ and $80 \%$ efficiency.

TABLE 10.8. Fuel 011 Boiler Capital and Operating Costs (197.6\$)

\begin{tabular}{|c|c|c|c|}
\hline & $\begin{array}{c}\text { Annual } \\
\text { Operating, } \\
\$ K \\
\end{array}$ & $\begin{array}{l}\text { Annual } \\
\text { Capital } \\
\text { Cost, \$K } \\
\end{array}$ & $\begin{array}{l}\text { Total } \\
\text { Annual } \\
\text { Cost \$K }\end{array}$ \\
\hline Operator ( $\$ 20 \mathrm{~K}$ ea, 4 shifts, 7 days/week) & 80 & & \\
\hline Assistant Operator $(15 \mathrm{~K}$ ea $)$ & 60 & & \\
\hline $100 \%$ Overhead & 140 & & \\
\hline 5-MW Plant & 280 & 9 & 289 \\
\hline 10-MW Plant (a) & 330 & 18 & 348 \\
\hline 20-MW Plant (a) & 400 & 35 & 435 \\
\hline
\end{tabular}

(a) Based on exponential 0.25 scaling factor

\subsection{FUEL REPROCESSOR SAVINGS - ARMY CREDIT FOR CANISTER STORAGE}

If proper planning and scheduling are coordinated it may be feasible to benefit the fuel reprocessor by decreasing (or, ideally, eliminating) their requirements for canister storage by using the waste canisters in Army steam plants. The $16 \mathrm{in.} \mathrm{diameter} 10 \mathrm{ft}$ long borosilicate glass canisters containing the waste from reprocessing 4.4 MTHM will be used as an example. This corresponds to Concept 1.2 and 2.2 with canister storage times of $8 \mathrm{yr}$. A 1500 MTHM/hr fuel reprocessing plant will produce 270016 in. diameter borosilicate glass canisters in $8 \mathrm{yr}$, and would require storage for the same number. The RSSF water basin concept-overpack was for about $300016 \mathrm{in}$. 0.D. canisters through the year 1990 which is similar to what a 1500 MTHM/yr reprocessing plant would require. Therefore, ideal1y, the Army steam plants could save the reprocessor the capital required for the storage facility and the associated operating costs of a RSSF water basin concept-overpack. (4) The Receiver Facility would still be required for the reprocessing plant to decontaminate and process the canisters for shipment, and a small storage area would be needed. 
The cost estimate for the fuel reprocessor's water basin storage is presented in Table 10.9. Sitework and yardwork were assumed to be $50 \%$ of the RSSF estimate and total cost was added for the Exhaust Air and Communications Systems. The total capital savings would be $\$ 20.7 \times 10^{6}$. Labor savings for the fue 1 reprocessor were estimated to be $\$ 1.24 \times 10^{6} / \mathrm{yr}$ which is the same as a 20-MW steam plant excluding management costs; these latter costs would already be required for the reprocessor's waste solidification plant. Utility savings for the reprocessor would also be about the same as for the 20-MW steam plant $(264,000 / y r)$ since a $20-M W$ plant would contain 2,880 16 in. diameter canisters (Concept 1.2 of 2.2) and a reprocessor's storage would have 2,700 canisters.

TABLE 10.9. Fuel Reprocessing Plant's Storage Facility Cost Savings

\begin{tabular}{lr}
\multicolumn{1}{c}{ Description } & \multicolumn{1}{c}{ Amount } \\
\cline { 2 - 2 } Sitework & 180,000 \\
Yard Work & 500,000 \\
Receiving Facility & Existing \\
Storage Area & $7,460,000$ \\
Waste Concentration & Existing \\
Exhaust Air System & 220,000 \\
Communications & 160,000 \\
Operations Building & Existing \\
Total Direct Costs (1973 $\$$ ) & $8,520,000$ \\
CE Plant Construction Index (August 1976) & 1.35 \\
& $11,502,000$ \\
Indirect Construction Costs (20\%) & $2,300,000$ \\
Total Construction Costs & $13,802,000$ \\
Design and Engineering (30\%) & $4,141,000$ \\
Design Uncertainties (20\%) & $2,760,000$ \\
Contingency (10\%) & $1,380,000$ \\
\cline { 2 - 2 } & $\$ 20,703,000$
\end{tabular}


The fuel reprocessor's savings must be distributed among the number of steam plants required to accept the reprocessing plant's total canister output. This is dependent on waste form and canister resupply rate for the steam plant. For example, using a $1500 \mathrm{MTHM} / \mathrm{yr}$ fuel reprocessing plant as a basis, the 16 in. diameter borosilicate glass canisters for Concepts 1.2 and 2.2 would each contain waste from about 4.4 MTHM. In 1 yr 340 canisters would be produced which would supply about four 5-MW, two 10-MW, or one 20-MW steam plant (resupply rate for 5-MW plant is 90 canisters/yr). The same type of calculation has been done for each concept; the results are given in Table 10.10. In estimating the savings for other waste forms, the fuel reprocessor's storage facility size will vary. This can be accounted for by multiplying the storage facility capital investment by the ratio of storage time and waste density to the 0.6 exponent. For example, to obtain the savings for Concepts 1.5 and 2.7, the capital investment for Concept 1.2 and 2.2 is multiplied by $(9 / 8)^{0.6}$, ratio of storage time, and multiplied by $(0.92 / 2.0)^{0.6}$, ratio of waste density of borosilicate glass to calcineA1 matrix; the result is $\$ 13.9 \times 10^{6}$ for the capital investment. The operating costs will be assumed to be equal for all concepts.

TABLE 10.10. Number of Army Steam Plants Required to Eliminate Fue? Reprocessor Canister Storage

\begin{tabular}{|c|c|c|c|c|c|c|c|c|c|}
\hline Concept & Waste Form & $\begin{array}{l}\text { Canister } \\
\text { Diameter, } \\
\text { in. }(\mathrm{cm})\end{array}$ & $\begin{array}{l}\text { Waste }(a) \\
\text { Contained/ } \\
\text { Canister, } \\
\text { MTHM } \\
\end{array}$ & $\begin{array}{c}\text { Canister }(b) / \\
\text { yr from } \\
\text { FRP } \\
\end{array}$ & $\begin{array}{c}\text { Canister } \\
\text { Resupply } \\
\text { per yr, } \\
5 \mathrm{MW} \\
\end{array}$ & $\begin{array}{l}\text { Number } \\
\text { Plants } \\
5 \text { Mi }\end{array}$ & $\begin{array}{l}\text { of St } \\
\text { Requi } \\
10 \mathrm{MW} \\
\end{array}$ & $\frac{\operatorname{eam}(c)}{20 \mathrm{MW}}$ & $\begin{array}{l}\text { FRP Storage } \\
\text { Facility } \\
\text { Capital } \\
\text { Investment, } \\
\$ \times 10^{6}(1976 \$)\end{array}$ \\
\hline $1.1,2.1$ & Borosilicate & $12(30.5)$ & 2.5 & 600 & 200 & 3 & 1.5 & 0.75 & 15.6 \\
\hline $1.2,2.2$ & Borosilicate & $16(40.6)$ & 4.4 & 340 & 90 & 4 & 2 & $i$ & 20.7 \\
\hline $1.3,2.3$ & Calcine-Al & $12(30.5)$ & $4.4^{(d)}$ & 340 & 90 & 4 & 2 & 1 & 15.6 \\
\hline $1.4,2.5$ & Calcine-Al & $16(40.6)$ & 6.9 & 217 & 26 & 8 & 4 & 2 & 20.7 \\
\hline $1.5,2.7$ & Caicine & $8(20.3)$ & 2.4 & 625 & 160 & 4 & 2 & 1 & 13.9 \\
\hline $1.6,2.8$ & Calcine & $10(25.4)$ & 3.8 & 395 & 90 & 4 & 2 & 1 & 13.9 \\
\hline 2.4 & Boros 11 icate & $20(50.8)$ & 6.9 & 217 & 26 & 8 & 4 & 2 & 20.7 \\
\hline 2.6 & Calcine-Al & $20(50.8)$ & 10.8 & 139 & 17 & 8 & 4 & 2 & 20.7 \\
\hline
\end{tabular}

(a) The amount of waste contained in a canister in MTHM processed.

(b) $1500 \mathrm{MTHM} / \mathrm{yr}$ production rate from fuel reprocessing plant (FRP).

(c) Number of steam plants required to el iminate the need for FRP canister storage.

(d) Assumed to be equal to concepts 1.2 and 2.2 ; may be closer to 4.0 MTHM/canister. 
For the concepts where the storage times are much larger than $8 \mathrm{yr}$, the situation is more complicated. On one hand, it could be assumed that the fuel reprocessor would be required to store the canisters the same time such as 27 years in Concepts 1.4 and 2.4. However, federal regulations state that within $10 \mathrm{yr}$ after separation of the HLW, a reprocessor has to ship the waste to a federal repository (see Appendix F, Reference 7). And, since the alternatives to $27 \mathrm{yr}$ storage by the fuel reprocessor are probably less costly, it will be assumed that the greatest savings would be for Concepts 1.2 and $2.2\left(\$ 20.7 \times 10^{6}\right)$ since the fuel reprocessor cannot store canisters longer than $10 \mathrm{yr}$. To credit the fuel reprocessor's savings to the Army, some method of payment for canister storage must be made by the fuel reprocessor. The payments should be devised to benefit both the Army and the fuel reprocessor. Differences exist between private industry and government economics. The fuel reprocessor would require a return on investment such as 15\%/yr which would in turn be paid by the utility users. Also, borrowed money for private industry is usually at a higher interest rate and for a shorter time than 7\% over $25 \mathrm{yr}$ for Army economics. If the Army stores the canisters, the risk of investing capital will also be eliminated. At this time, it will be assumed that the amount the fuel reprocessor would be willing to pay the Army will be the capital cost at $7 \%$ over $25 \mathrm{yr}$, the annual operating cost, and the maintenance costs for the fuel reprocessor's conceptual storage facility. Also, the potential transportation costs from the fuel reprocessor to the disposal site will be paid as discussed in Section 9.3 on Transportation. The benefit to the Army is credit for storage. The benefits to the reprocessor are reduced capital risk, the use of government economics (10wer interest rate over longer period) and being relieved of management of canister storage. The fuel reprocessor may decide to charge a fee (which would eventually be paid by the utility users) equal to the annual service charge paid to the Army, but this has no bearing on the Army plant economics. 
There exist many other methods to calculate fuel reprocessor payments to the Army. At this time the one presented here seems simple and fair to both parties. Future more detailed analysis with input by all affected parties may be warranted before decisions are made to proceed with plans for canister storage by the Army.

The credits to the Army paid by the fuel reprocessor are presented in Table 10.11. The distribution for the various concepts and plant sizes are based on the information in Table 10.10. TABLE 10.11. Annual Cost of Canister Storage to the Fuel Reprocessor -
Potential Credit to the Army, $\$ \times 10^{3}(1976 \$)$

\begin{tabular}{|c|c|c|c|c|}
\hline Concept & $\begin{array}{c}\text { Plant Size, } \\
\text { MW }\end{array}$ & Operating & Capital & Total \\
\hline $1.1,2.1$ & $\begin{array}{r}5 \\
10 \\
20\end{array}$ & $\begin{array}{r}500 \\
1000 \\
2000\end{array}$ & $\begin{array}{r}650 \\
1300 \\
2600\end{array}$ & $\begin{array}{l}1160 \\
2300 \\
4600\end{array}$ \\
\hline $1.2,2.2$ & $\begin{array}{r}5 \\
10 \\
20\end{array}$ & $\begin{array}{r}375 \\
750 \\
1500\end{array}$ & $\begin{array}{r}650 \\
1300 \\
2600\end{array}$ & $\begin{array}{l}1025 \\
2050 \\
4100\end{array}$ \\
\hline $1.3,2.3$ & $\begin{array}{r}5 \\
10 \\
20\end{array}$ & $\begin{array}{r}375 \\
750 \\
1500\end{array}$ & $\begin{array}{r}488 \\
975 \\
1950\end{array}$ & $\begin{array}{r}863 \\
1725 \\
3450\end{array}$ \\
\hline $\begin{array}{l}1.4,2.5 \\
2.4,2.6\end{array}$ & $\begin{array}{r}5 \\
10 \\
20\end{array}$ & $\begin{array}{l}188 \\
375 \\
750\end{array}$ & $\begin{array}{r}323 \\
647 \\
1294\end{array}$ & $\begin{array}{r}511 \\
1022 \\
2044\end{array}$ \\
\hline $\begin{array}{ll}1.5, & 2.7 \\
1.6,2.8\end{array}$ & $\begin{array}{r}5 \\
10 \\
20\end{array}$ & $\begin{array}{r}375 \\
750 \\
1500\end{array}$ & $\begin{array}{r}434 \\
869 \\
1738\end{array}$ & $\begin{array}{r}810 \\
1619 \\
3238\end{array}$ \\
\hline
\end{tabular}

\subsection{OVERALL ECONOMICS}

The analysis of the overall economics of Army steam plants fueled with high-level waste canisters will be based on equivalent fuel oil price. The oil price is defined here as the price that fuel oil would have to be or would have to increase to in order for steam plants fueled with HLW canisters to economically compete with fuel oil boilers. The annual capital and operating costs for steam plants are divided by the fuel $0 i 1$ requirements 
$\left(5-, 10-\right.$, and $20-\mathrm{MW}$ require $1.5 \times 10^{6}, 3.0 \times 10^{6}$, and $6.0 \times 10^{6} \mathrm{ga} 1 / \mathrm{yr}$, respectively). Then yearly transport costs are also divided by the fuel oil requirement (see Section 9.3); the transport costs in price/gal fuel oil are identical for all plant sizes for each concept. The annual capital and operating savings for replacing a fuel oil boiler (not including the fuel oil) and the storage credit for eliminating fuel reprocessor canister storage are also divided by the appropriate fuel oil requirement. In this manner, the contribution of each cost factor can be expressed in equivalent price (or value) of fuel oil. For further explanation of this method of economic comparison, the following equations apply:

For economic feasibility on an annual basis, HLW Canister Plants Costs (Capital Cost + Operating Cost + Indirect Canister Transport Cost + Initial Canister Loading Cost) - Credit from Fuel Reprocessor for Canister Storage (Capita 1 Cost + Operating Cost + Direct Transportation Cost) $=$ Fuel $0 i 1$ Plant Cost [Capital Cost + Operating Cost + (Fuel $0 i 1$ Required x Fuel $0 i 1$ Price)].

Using abbreviations,

$C_{H L W}+0_{H L W}+I T_{H L W}+I C L_{H L W}-C_{F R}-O_{F R}-D T_{F R}=C_{F O}+0_{F O}+(F O \times \$ / g a 1)$

Then rearranging Overall Cost in Equivalent Fuel $0 i 1$ Price, $\$ / g a l=$ $\left(C_{H L W}+0_{H L W}+I T_{H L W}+I C L_{H L W}-C_{F R}-0_{F R}-D T_{F R}-F_{F O}+0_{F O}\right) / F O$.

The overall cost in equivalent fuel oil price could be defined as the "break-even" price for fuel oil. Any fuel oil price less than this value indicates fuel $0 i 1$ systems are more economical, and any price higher indicates HLW canister steam plants are more economical.

The overall costs will be presented for all the concepts for the most cost effective situation which assumes:

1) The fuel reprocessor's need for a canister storage facility is eliminated and the savings are credited to the Army based on a capital recovery factor of $0.125(0.086$ for a $7 \%$ interest rate over $25 \mathrm{yr}$ and 0.039 for maintenance). Transportation costs of the fuel reprocessor are credited. 
2) The Army owns the transport casks and charges $\$ 1030 /$ cask/day. The casks are used 365 days/yr by a combination of the Army, fuel reprocessor, and waste disposal facility.

3) The receiving facility designed for the 5-MW plant is adequate for the 10- and 20-MW plants.

Table 10.12 summarizes the plant costs for $5-, 10-$, and $20-M W$ plants based on the above assumptions and steam plants located at Fayetteville, North Carolina and Columbus, Georgia and disposal facilities at Carlsbad and Alpena, respectively (transport routes 4 and 12).

The highest overall costs are for Concept 1 with stainless steel special equipment. These are followed by concept 1 with carbon steel special equipment. The lowest costs are for concept 2. In all cases, the overall costs are reduced as plant size is increased.

The 12 in. diameter borosilicate glass canister, Concept 2.i, appears to be the most cost competitive due to the relatively low transportation costs. A 20-MW plant located at Fayetteville would have an overall cost of $\$ 0.58 /$ gal fuel 011 . The actual cost for concept 2.1 would be somewhat higher than $\$ 0.58 /$ gal because a plant the size of Barnwell could only supply a 15-MW plant (see Table 10.10) or canisters would be needed from another, possibly more distant, fuel reprocessing plant to supply a 20-MW plant. The same plant at Columbus would require fuel oil prices of $\$ 0.95 / g a l$ to be cost competitive. Thus, the location of the plant in relation to the fuel reprocessor is important. The 16 in. diameter glass canister, Concept 2.2, which is considered to be the most likely canister produced initialiy has an overall cost of $\$ 0.76 / \mathrm{gal}$ (20-MW at Fayetteville) and \$1.01/gal (20-MW at Columbus). Concept 2.5 and 2.6 show Calcine-Al matrix to provide potential low overall costs of $\$ 0.61 / \mathrm{gal}$ and $\$ 0.66 / \mathrm{gal}$ (20-MW at Fayetteville). However, for these latter costs to be achieved, two 20-MW plants would need to be located within 200 miles of the fuel reprocessing plant in order to fully eliminate a reprocessor's storage requirement (see Table 10.10). 


\section{TABLE 10.12. Overall Steam Plant Cost in Equivalent Fuel 0il Price $(1976 \$)^{(a)}$}

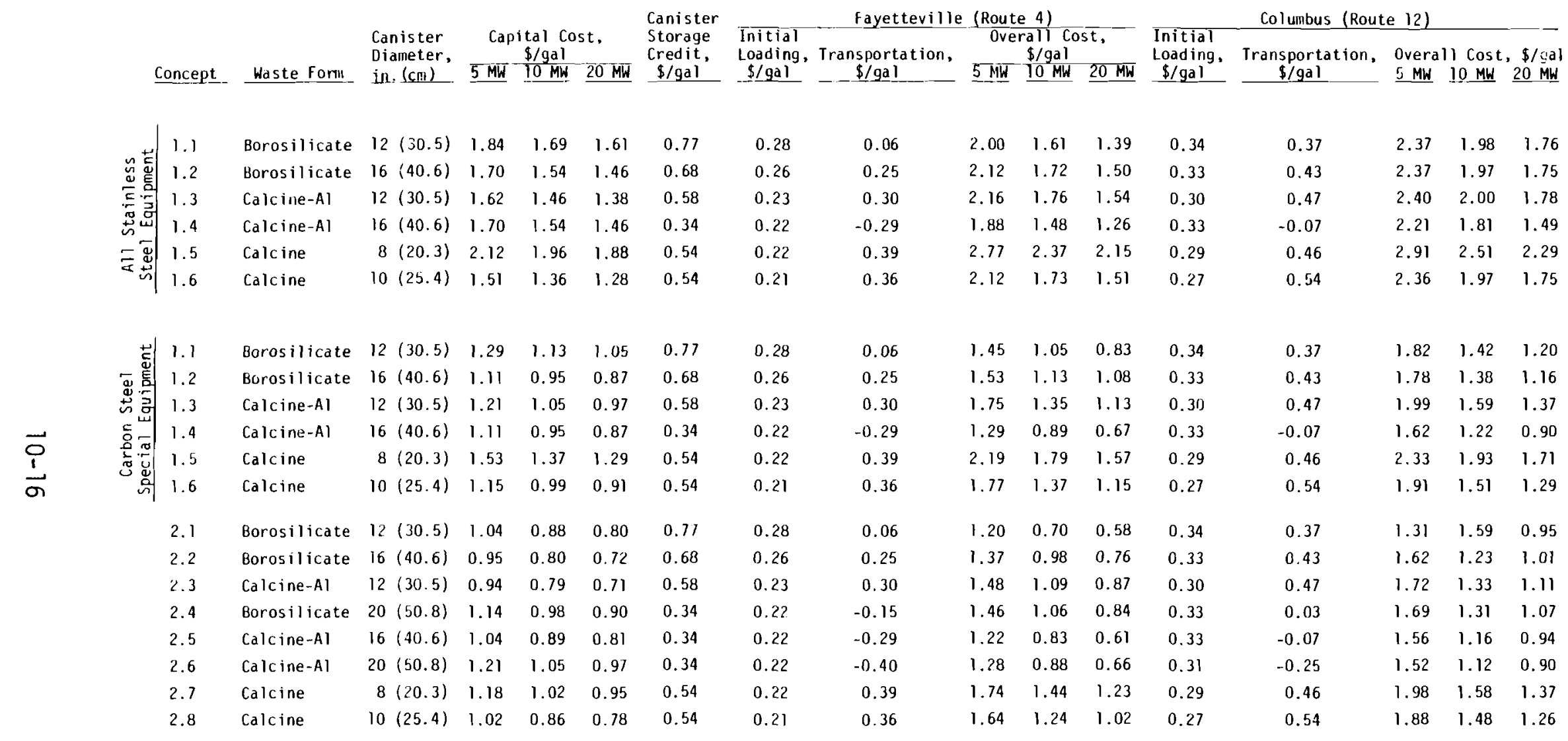

(a) Army owns casks.

Overall Steam Plant Cost $=$ Steam Plant Capital Cost

+ Operating Cost - Fuel 0il Boiler Savings (Capital and Operating)

- Credit for Storage + Initial Canister Loading cost + Canister Transportation Cost

Steam Plant Operating Costs are $0.78,0.47$, and $\$ 0.28 /$ gal and Fuel 0 il Boiler Savings are

$0.19,0.12$, and $\$ 0.07 / \mathrm{gal}$ for 5,10 , and $20 \mathrm{MW}$ steam plants, respectively. 
Recent information (January 1977) available from Sandia Laboratories' conceptual design of the Waste Isolation Pilot Plant recent salt mine limits may be reduced to $3.5 \mathrm{~kW}$ in a $13.1 \mathrm{in} .(33.3 \mathrm{~cm})$ internal diameter canister. The effect of reducing the diameter and heat load from 16 in. and $5 \mathrm{~kW}$ which was used as a basis for cost estimates in Table 10.12 to these lower values would increase the costs of a steam plant. A 5-MW plant would require a total of 1120 canisters stored for $8 \mathrm{yr}$, and the canister resupply rate would be 150/yr. Based on the other cost estimates, the overall cost would probably be close to $\$ 1.00 /$ gal for a 20 -MW plant located at Fayetteville if these canister restrictions are imposed.

The credit for storage of the canisters is extremely important. In Concept 2.1 , the storage credit is $\$ 0.77 / \mathrm{gal}$ which is about equal to the capital cost of a $20-\mathrm{MW}$ plant $(\$ 0.80 /$ gal) and the final equivalent overall cost $\$ 0.58 / \mathrm{gal}$. Thus without credit or only partial credit for storage, the overall equivalent cost would be between $\$ 0.58$ and $\$ 1.35 /$ gal. If the transportation credit of $\$ 1.39 / \mathrm{gal}$ were not fully received the overall cost would increase to between $\$ 0.58$ and $\$ 1.97 / \mathrm{gal}$. If both these preceding credits were not received, overall cost would be $\$ 2.74 /$ gal. The dependency of all the other concepts on these credits is similar. Without storage credit the $20-\mathrm{MW}$ plant in Concept 2.2 overall equivalent cost would increase between $\$ 0.76$ to $\$ 1.44 /$ gal and loss or reduction of transportation credit would increase equivalent overall costs by $\$ 0.95 /$ ga 1 , between $\$ 0.76$ and $\$ 1.71 /$ gal. Loss of both credits would result in a cost of $\$ 2.39 / \mathrm{gal}$. Another important factor is ownership of casks by the Army. If the fuel reprocessor owns the casks the base overall cost in Concept 2.2 for 20-MW would be $\$ 1.41 /$ gal instead of $\$ 0.76 /$ gal. Concept 2.1 would be $\$ 1.02 /$ ga 1 instead of $\$ 0.57 / g a 1$. Related to cask ownership is the assumption of full cask use if the Army owns them. If these are not fully used, for example 1 month/yr they are idle, the additional equivalent cost in Concept 2.2 for three casks would be $\$ 0.06 / \mathrm{gal}$. Other costs for research and development and 1 icensing could add another $\$ 0.04$ to $\$ 0.08 /$ gal. Another factor is the Receiving Facility. If a hot cell type receiving facility were needed for either handling the relatively high canister delivery rate of the $20-\mathrm{MW}$ 
size plants or for licensing, the incremental costs would be $\$ 0.27 / \mathrm{gal}$, $\$ 0.13 / \mathrm{gal}$, and $\$ 0.07 / \mathrm{gal}$ for $5-, 10$ - and $20-\mathrm{MW}$ plants, respectively.

The final question is should these plants be built? Based on today's fuel oil prices of about $\$ 0.45 / \mathrm{gal}$, the steam plants are not cost competitive and should not be built. However, fuel oil prices are increasing and in the future these plants could be competitive. A prediction of when this will occur is complicated since the cost of the materials used in the steam plant, transportation costs, etc. are all increasing. The fuel oil cost must increase faster than the other costs (such as $8.8 \%$ for rail transport). Since the present economy is strongly dependent on 011 prices, it may be 5 to $10 \mathrm{yr}$ before these plants could be economically justified. Also, many factors would be involved in building and operating an economic steam plant fueled with high-level waste canisters at the earliest possible date. These are:

- The need for canister storage by the fuel reprocessor must be el iminated and the fuel reprocessor must be willing to pay the Army some portion of the storage costs (capital, operating, and transportation).

- The steam plant will need to be about 20-MW and located within 200 miles of the fuel reprocessing plant.

- The capital cost for a 20 -MW plant should be about $\$ 40 \times 10^{6}$ or less in 1976 dollars.

The preceding economic analys is shows that the concept of fueling steam plants with HLW canisters may have merit for future implementation, but requires cautious analysis. In other words, this present study does not definitely rule out the possibility of this concept being economically feasible in the future. On this basis, the next section discusses development plans.

The final section updates some of the assumptions made in the previous sections (which were made during 1976), discusses the impact of this update on the economic feasibility of these plants, and makes recommendations. 
11.0 DEVELOPMENT PLANS 


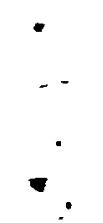




\subsection{DEVELOPMENT PLANS}

A major conclusion of the previous section on economics is that the fue 1 reprocessor must pay the Army for storage and transport of the canisters to ensure the economic feasibility of Army steam plants fueled with HLW canisters. Therefore, development plans for these steam plants must coincide with fuel reprocessor schedules to eliminate the latter's canister storage requirements.

The estimates for the time required to build an RSSF-water basin con-

cept $^{(8)}$ are 6 to 9 months to complete the conceptual design; 9 to 12 months to complete the design criteria, select an architect-engineer, and start the preliminary design; and an additional $6 \mathrm{yr}$ to complete the design and construction. The total time to complete the above tasks is 7 to $8 \mathrm{yr}$. The conceptual design of the RSSF is further along than the Army steam plant conceptual design; and the technology of the RSSF design is well known (where there are some uncertainties in the Army concepts, see Section 8.6). The time to complete an Army steam plant is estimated at 8 to $10 \mathrm{yr}$ including 1 to $2 \mathrm{yr}$ for conceptual design and testing.

It is expected that the first reprocessing plant to produce HLW canisters is AGNS which may begin operation in 1979, and produce the first 2-yrold solidified waste in 1983. It was estimated that the NFS plant would begin operation in 1983 and produce 5-yr-old waste for $10 \mathrm{yr}$. However, the NFS plant may never operate again; a possibility is AGNS reprocessing the spent fuel that NFS was going to process. If this occurred, it could be 1987 before AGNS would produce 2-yr-old waste. The question about whether the Army could use AGNS canisters economically depends on the canister storage requirements and the number of canisters needed for pilot studies of permanent disposal methods. If AGNS needed a relatively large canister storage facility before 1985, an Army steam plant's economic feasibility would be reduced. AGNS will need a storage facility before 1985 unless waste disposal pilot-plants can use the canisters which are produced. Since it is not expected that the pilot-plants will be ready until 1985 (see Section 6.0) it is likely that an Army steam plant could not be ready in time to eliminate AGNS canister storage requirements. 
The next plant that would begin operation in 1984 at the earliest would be a $1500 \mathrm{MTHM} / \mathrm{yr}$ plant proposed by Exxon Nuclear Co., Inc.; (6) preliminary siting is Oak Ridge, Tennessee. Exxon will also probably reprocess "old" fuel for several years; 2-yr-old waste might be available as early as 1986 or 1987. With this timing, an Army steam plant could be ready to accept Exxon canisters, but the decision to proceed with detailed design and construction of an Army steam plant would have to be made by 1978 at the latest. That allows about 2 yr to confirm conceptual design and econcmic feasibility. For that reason, the following steps are recommended:

1. The fuel reprocessor's willingness to pay the Army for storing canisters and the appropriate amount to be paid should be determined.

2. The Nuclear Regulatory Commission should be consulted on steam plant licensing.

3. The economics should be revised based on Steps 1 and 2 above.

4. A research and development plan should be developed if the economics warrant further work.

5. Periodic reviews should be made of nuclear waste management, nuclear regulations, steam plant costs, etc., to be certain the plants are still uneconomical or economical, as the case may be.

The development plans outlined above are based on information gathered during 1976. The next section outlines more current information, how it affects the previous results and development plans, and recommendations are made on the concept of using solidified waste fission product canisters in an Army steam plant. 
12.0 UPDATE AND RECOMMENDATIONS 
$\cdot$
$-\cdot$
$\cdot$
$\therefore$ 


\subsection{UPDATE AND RECOMMENDATIONS}

Work started on this economic analysis in early March 1976 . Since that time, particularly from January 1977 onward, developments have occurred which significantly affect the results. These are:

1. The uncertainty of the future of nuclear fuel reprocessing; it may never occur or, at least, there will probably be more delays imposed on fuel reprocessing plant start-up and on the availability of solidified waste fission product canisters. On Apri1 7, 1977, President Carter made the following statement concerning nuclear power policy:

"First we will defer indefinitely the commercial reprocessing and recycling of the plutonium produced in U.S. nuclear power programs. From our own experience we have concluded that a a viable and economic nuclear power program can be sustained without such reprocessing and recycing. The plant at BarnwelI, SC, will not be completed as a reprocessing facility."

2. The decision to not resume operation of the Nuclear Fuels Services Inc. (NFS) fuel reprocessing plant located in West Valley, New York.

3. More definite plans and scheduling by ERDA-Office of waste Isolation on the pilot plants for waste disposal.

4. The possibility of reducing the maximum heat load of a canister deposited in salt mine final disposal to $3.5 \mathrm{~kW}$ (where $5.0 \mathrm{~kW}$ was used as a basis in this study).

The most influential of the items listed above is Item 1. At this time, there exists the possibility that canisters may never become available for fueling Army steam plants. On this basis and the fact that the economics today are borderline (see Section 10.0), the use of solidified waste fission products to fuel Army steam plants need not be considered further until a definite decision is made to reprocess spent nuclear fuel.

The effect of Item 2 is to increase the backlog of spent nuclear fuel in storage awaiting reprocessing by other plants (AGNS and Exxon). This will delay the availability of 2-yr-old solidified waste. In conjunction 
with present Administration's policy (see Item 1) the availability of 2-yrold waste will be further delayed. Both of these facts may eliminate the availability of canisters containing 2-yr-old waste; when fuel reprocessing plants would begin operation, they may never "catch-up" with the backlog of spent fuel. The result will be an increase in the steam plant's inventory of canisters needed for a specific power output, an increase in plant size, and an overall increase in the equivalent fuel oil price for the steam plant (price of fuel oil at which a steam plant fueled with waste canisters would economically compete). The effects of Items 3 (see Section 6.0) and 4 (see Section 10.0) increase the likelihood of a delay in canister availability and an increase in steam plant costs.

The idea of using waste heat from radioactive waste is basically sound. However, because of the uncertainties which envelop the nuclear fuel cycle, the further near-term consideration of using solidified waste fission products to fuel Army steam plants need not be made. In light of the items listed above, it is recommended that this concept not be considered again until a firm fuel reprocessing plant start-up schedule has been established. Once that occurs the development plans outlined in Section 11.0 would be justified following an update of the entire present study.

In conclusion, it is hoped that the present study can be used as a basis for future work. Since delays in fuel reprocessing are likely, increased quantities of spent nuclear fuel elements, which also generate heat, will require storage. It may be feasible to apply the concepts (and cost estimates) outlined here to considering steam plants fueled with spent nuclear fuel elements. The design of this type of plant would need to address factors such as criticality control, release of radioactive gases from leaking fuel elements, and secondary encapsulation of leaking fuel elements (see Section 7.4). 
13.0 ACKNOWLEDGMENTS 


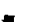

-

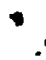




\subsection{ACKNOWLEDGMENTS}

This work was sponsored by the U.S. Army, Facilities Engineering Support Agency, Fort Belvoir, VA, and the Energy Research and Development Administration-Division of Nuclear Research and Applications.

A number of Battelle, Pacific Northwest Laboratory's staff contributed to this report. W. J. Bjorklund was assisted by C. C. Chapman and S. C. Slate with the portions of this report dealing with Philosophies, Forecast of Solidified Waste Supply, Present Waste Solidification Strategy, and Alternate Solidification Strategies and Processes. N. A. Brooks with review by R. J. Hall provided the section on Transportation. R. J. Cena assisted with boiler heat transfer analysis and $S$. W. Wilson computed canister temperature distributions. L. M. Browne assisted with equipment design. Overa11 program management was provided by J. H. Jarrett. The detailed review of this report by M. O. Cloninger and H. T. Fullam was appreciated. Report editing was provided by J. L. Simmons and typing by D. J. Kennedy and M. V. Heid.

An important contribution was made by J. R. La Riviere; ${ }^{(a)}$ Atlantic Richfield Hanford Company, in supplying information on the Retrievable Surface Storage Facility and in reviewing the use of that information in this report.

(a) Presently with Scientific Applications, Inc., Richland, WA. 


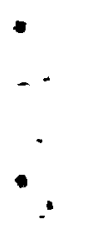

$\therefore$ 
APPENDIX A

BASES FOR PROJECTIONS OF CAPACITY, MATERIALS FLOWS, AND WASTE GENERATION INVOLVING LIGHT WATER REACTORS (LWRS) 
$\cdot$
$\ldots$
$\cdot$
$\therefore$ 
APPENDIX A

BASES FOR PROJECTIONS OF CAPACITY, MATERIALS FLOWS, AND WASTE

GENERATION INVOLVING LIGHT WATER REACTORS (LWRS) ${ }^{(8)}$

Projections of parameters have been selected to characterize the Light Water Reactor (LWR) fuel cycle in the period 1976 through 2000. (a) The assumptions upon which these projections are based ${ }^{(36)}$ are presented, as a collection, in this section. These parameters include LWR operating capacity, the flow and accumulation of primary wastes, and the flow of various other materials necessary to the operation of a complete LWR fuel cycle.

The ratio of Pressurized Water Reactors (PWRs) to Boiling Water Reactors (BWRs) $=2: 1$. Plant factors are $40 \%$ during the pre-operational period between fuel loading and commercial operation, 65\% during the first $2 \mathrm{yr}$ of commercial operation, $70 \%$ for years 3 through 15, and following the 15th year, decline at 2 percentage points per year to a minimum of $40 \%$. Uranium is recycled as soon as material can be returned through normal fuel cycle timing. Plutonium is recycled beginning with $25 \%$ of the reactors in $1981,50 \%$ of reactors in 1982, $75 \%$ of reactors in 1983, and without constraint in following years except that sufficient plutonium is withheld for use in Fast Breeder Reactors (FBRs). Average burnup at discharge and power level during irradiation will differ slightly for BWRs and PWRs and will increase somewhat during the period 1975 to 2000. The burnup of fuel at discharge determines several factors of importance to waste management including the composition, thermal power, and gamma power of high level waste. Most of the planning for an LWR fuel cycle has been done on the basis of a fuel burnup of 33,000 MWd/MTHM. (b) This burnup level is expected to be characteristic of future LWR fuel, and the average burnup of fuel discharged to the present, now in storage and slated for processing between 1975 and 2000, will be lower. Calculations of projections are presently available only for a burnup of 33,000 MWd/MTHM, and these numbers are the

(a) The projections presented here are outdated as of April 1977. Future work should use more current projections.

(b) Megawatt day/metric tonne heavy metal. 
basis for the projections presented. Since higher burnup will increase the amounts of longer-lived radioisotopes to be found in waste, these projections will be conservative in that estimates of activities associated with the wastes will tend to be high. Plutonium recycle in the PWR assumed selfsustaining recycle that uses a mixture of assemblies that contain either enriched uranium (PWR-U) or plutonium mixed with natural uranium (PWR-Pu). These assemblies are assumed to be shipped and reprocessed together, such that the plutonium product and wastes will be blended. LWR fuel is assumed to be reprocessed after a postirradiation decay time of 150 days.

High-level wastes are those aqueous wastes resulting from the operation of the first cycle solvent extraction system, or equivalent, and the concentrated wastes from subsequent extraction cycles, or equivalent, in a facility for reprocessing irradiated reactor fuels. These wastes contain virtually all of the nonvolatile fission products, several tenths of one percent of the uranium and plutonium originally in the spent fuels, and all the other actinides formed by transmutation of the uranium and plutonium in the reactors. Present regulations call for these wastes to be solidified within 5 years after they are generated and for the resultant stable solids to be shipped to a Federal repository within $10 \mathrm{yr}$ after the liquids are generated. (37) In the characterization of these wastes, reprocessing flowsheets were assumed that minimized, wherever possible, the additions of chemicals which might be particularly troublesome in subsequent waste management operations, specifically, sodium and sulfate ions. Product losses are taken as $0.05 \%$ of the Pu to the LWR cladding; $0.1 \%$ of the Pu and $U$ to be aqueous raffinates; ${ }^{(a)}$ and $0.01 \%$ of the $\mathrm{Pu}$ and $U$ to the solvent during stripping (which ultimately appears in the solvent regenerants). The actual volumes of high-level waste will depend on many factors that must be resolved through actual operating experience. Although waste management economics will tend to force the final volumes toward smaller values, additional wastes arising from maloperations, equipment decontamination, etc., will tend to increase them. Similarly, possible future requirements for

(a) This level of residual contamination is adequate for projections, similar to the 33,000 MWd/MTHM burnup. 
higher-quality waste products (less leachable in water, more radiationresistant) may also result in higher volumes of waste per ton of fuel processed. In view of these possibilities, an upper-limit volume for solidified high-level waste of $6 \times 10^{4} \mathrm{~cm}^{3} /$ MTHM processed (based on waste in the form of oxides with minor additions of $\mathrm{NaOH}$ or $\mathrm{B}_{2} \mathrm{O}_{3}$ to prevent volatilizing of some components) is used in the calculation of volumes of solidified highlevel waste.

Although solidification of commercial high-level wastes has not as yet been practiced, indications are that these materials may be packaged in steel canisters typically $\sim 30 \mathrm{~cm}$ in diameter by $300 \mathrm{~cm}$ long. As many as 12 such canisters (each containing $2 \times 10^{5} \mathrm{~cm}^{3}$ of $10-y \mathrm{r}$-0ld solidified waste) could be shipped by rail in a single cask. $(38,39)$

Based on the above assumptions, projected LWR operating capacity, and predicted fuel reprocessor capacity, the following tables are presented:

- Table A.1 - Projected Nuclear LWR Operating Capacity

- Table A.2 - Predicted Distribution of LWR Spent Fuel Reprocessing Among U.S. Facilities in the Near Term

- Table A.3 - Comparison of Reprocessing Requirements and Activities

- Table A.4 - Predicted LWR High-Level Waste Addition and Accumulation

- Table A.5 - Containers of 10-year-old LWR High-Level Waste Shipped

- Table A.6 - Projected Accumulation of Solidified LWR High-Level Wastes at a Federal Repository 
TABLE A.1. Projected Nuclear LWR Operating Capacity(a)

$\begin{array}{lr}\text { Year } & \text { GWe } \\ 1975 & 38.0 \\ 1976 & 44.3 \\ 1977 & 51.3 \\ 1978 & 58.4 \\ 1979 & 65.5 \\ 1980 & 75.5 \\ 1981 & 92.3 \\ 1982 & 112.7 \\ 1983 & 133.9 \\ 1984 & 157.4 \\ 1985 & 179.4 \\ 1986 & 202.0 \\ 1987 & 225.6 \\ 1988 & 254.0 \\ 1989 & 284.0 \\ 1990 & 315.6 \\ 1991 & 348.7 \\ 1992 & 382.7 \\ 1993 & 416.6 \\ 1994 & 450.7 \\ 1995 & 483.9 \\ 1996 & 516.2 \\ 1997 & 547.6 \\ 1998 & 579.1 \\ 1999 & 609.7 \\ 2000 & 638.6\end{array}$

(a) Reference 40 , based on assumptions summarized in text. 
TABLE A.2. Predicted Distribution of LWR Spent Fuel Reprocessing Among U.S. Facilities in the Near Term (a)

\begin{tabular}{|c|c|c|c|c|c|}
\hline \multirow[b]{2}{*}{ Year } & \multicolumn{5}{|c|}{ MTHM/yr } \\
\hline & $\operatorname{AGNS}^{(b)}$ & $\mathrm{NFS}^{(c)}$ & Exxon & $\begin{array}{c}\text { New } \\
\text { Capacity } \\
\end{array}$ & Total \\
\hline 1977 & 500 & & & & 500 \\
\hline 1978 & 1000 & & & & 1000 \\
\hline 1979 & 1500 & & & & 1500 \\
\hline 1980 & 1500 & 300 & & & 1800 \\
\hline 1981 & 1500 & 600 & & & 2100 \\
\hline 1982 & 1500 & 600 & & & 2100 \\
\hline 1983 & 1500 & 600 & 500 & & 2600 \\
\hline 1984 & 1500 & 600 & 1000 & & 3100 \\
\hline 1985 & 1500 & 600 & 1500 & & 3100 \\
\hline 1986 & 1500 & 600 & 1500 & 1000 & 4100 \\
\hline 1987 & 1500 & 600 & 1500 & 1000 & 5100 \\
\hline
\end{tabular}

(a) See following table for projected reprocessing schedules to year 2000.

(b) Allied-General Nuclear Services.

(c) Nuclear Fuel Services. The future of this plant is not certain; it may not operate again (see Section 4.0). 
TABLE A.3.
Comparison of Reprocessing
Requirements and Activities

\begin{tabular}{|c|c|c|}
\hline Year & $\begin{array}{c}\text { Actual LWR } \\
\text { Reprocessing Load } \\
\text { (MTHM) } \\
\end{array}$ & $\begin{array}{l}\text { LWR Fuel } \\
\text { Reprocessed } \\
\text { (MTHM) }\end{array}$ \\
\hline 1975 & 494.7 & \\
\hline 1976 & 712.9 & \\
\hline 1977 & 900.3 & 500.0 \\
\hline 1978 & $1,075.2$ & $1,000.0$ \\
\hline 1979 & $1,259.5$ & $1,500.0$ \\
\hline 1980 & $1,435.2$ & $1,800.0$ \\
\hline 1981 & $.1,631.5$ & $2,100.0$ \\
\hline 1982 & $1,910.0$ & $2,100.0$ \\
\hline 1983 & $2,298.4$ & $2,600.0$ \\
\hline 1984 & $2,762.0$ & $3,100.0$ \\
\hline 1985 & $3,284.0$ & $3,100.0$ \\
\hline 1986 & $3,840.2$ & $4,100.0$ \\
\hline 1987 & $4,397.3$ & $5,027.5$ \\
\hline 1988 & $4,965.4$ & $4,965.4$ \\
\hline 1989 & $5,577.8$ & $5,577.8$ \\
\hline 1990 & $6,250.3$ & $6,250.3$ \\
\hline 1991 & $6,961.0$ & $6,961.0$ \\
\hline 1992 & $7,719.4$ & $7,719.4$ \\
\hline 1993 & $8,515.0$ & $8,515.0$ \\
\hline 1994 & $9,314.4$ & $9,374.4$ \\
\hline 1995 & $10,153.8$ & $10,153.8$ \\
\hline 1996 & $10,975.9$ & $10,975.9$ \\
\hline 1997 & $11,744.9$ & $11,744.9$ \\
\hline 1998 & $12,515.3$ & $12,515.3$ \\
\hline 1999 & $13,267.7$ & $13,267.7$ \\
\hline 2000 & $14,044.8$ & $14,044.8$ \\
\hline
\end{tabular}

(a) Based on assumptions summarized in text. 


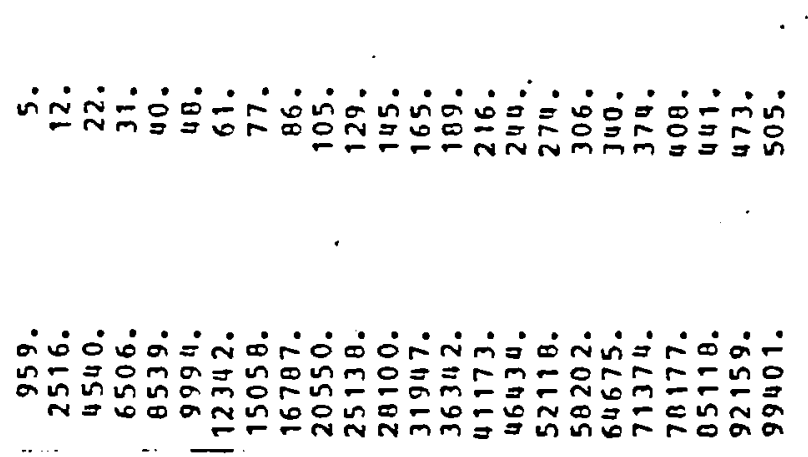

nummonorn=omaomrmamromno

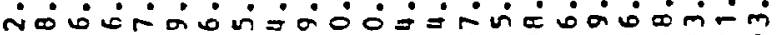

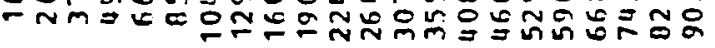

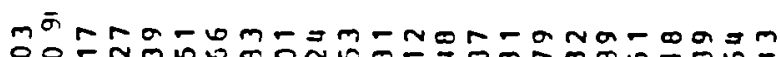

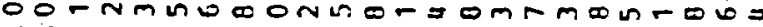

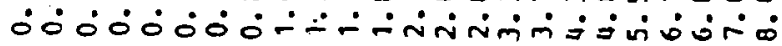

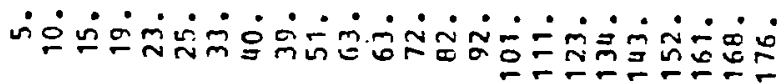

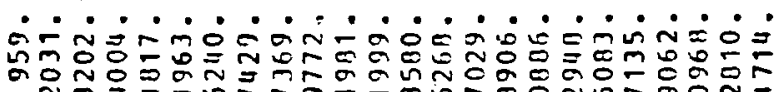

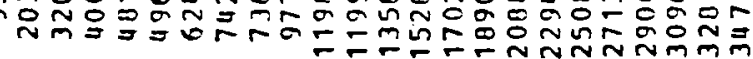

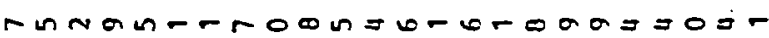

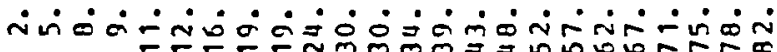

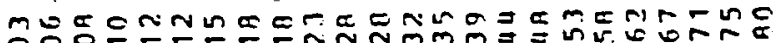
ó $\dot{0} \dot{0} 0 \dot{0} \dot{0} \dot{0} 0 \dot{0} \dot{0} 0 \dot{0} 0 \dot{0} 0 \dot{0}$

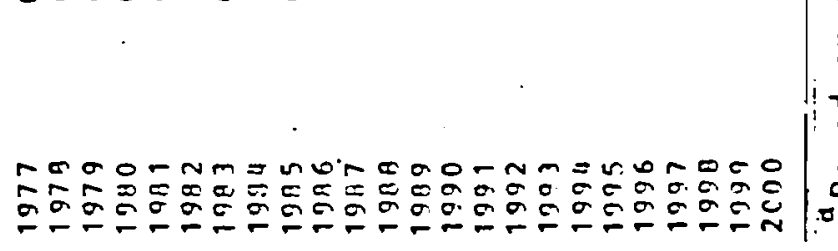


TABLE A.5. Containers of 10-yr-old LWR High-Leve l Waste Shipped (a)

\begin{tabular}{cc} 
Year & $\begin{array}{c}\text { Number of } \\
\text { Containers }\end{array}$ \\
\hline 1987 & 159.2 \\
1988 & 318.5 \\
1989 & 477.7 \\
1990 & 573.3 \\
1991 & 668.8 \\
1992 & 668.8 \\
1993 & 828.1 \\
1994 & 987.3 \\
1995 & 987.3 \\
1996 & $1,305.8$ \\
1997 & $1,601.3$ \\
1998 & $1,581.5$ \\
1999 & $1,776.5$ \\
2000 & $1,990.7$ \\
2001 & $2,217.1$ \\
2002 & $2,458.6$ \\
2003 & $2,712.0$ \\
2004 & $2,966.6$ \\
2005 & $3,234.0$ \\
2006 & $3,495.8$ \\
2007 & $3,740.8$ \\
2008 & $3,986.1$ \\
2009 & $4,225.8$ \\
2010 & $4,473.3$ \\
& \\
\hline 194 &
\end{tabular}

(a) Based on assumptions summarized in text. 


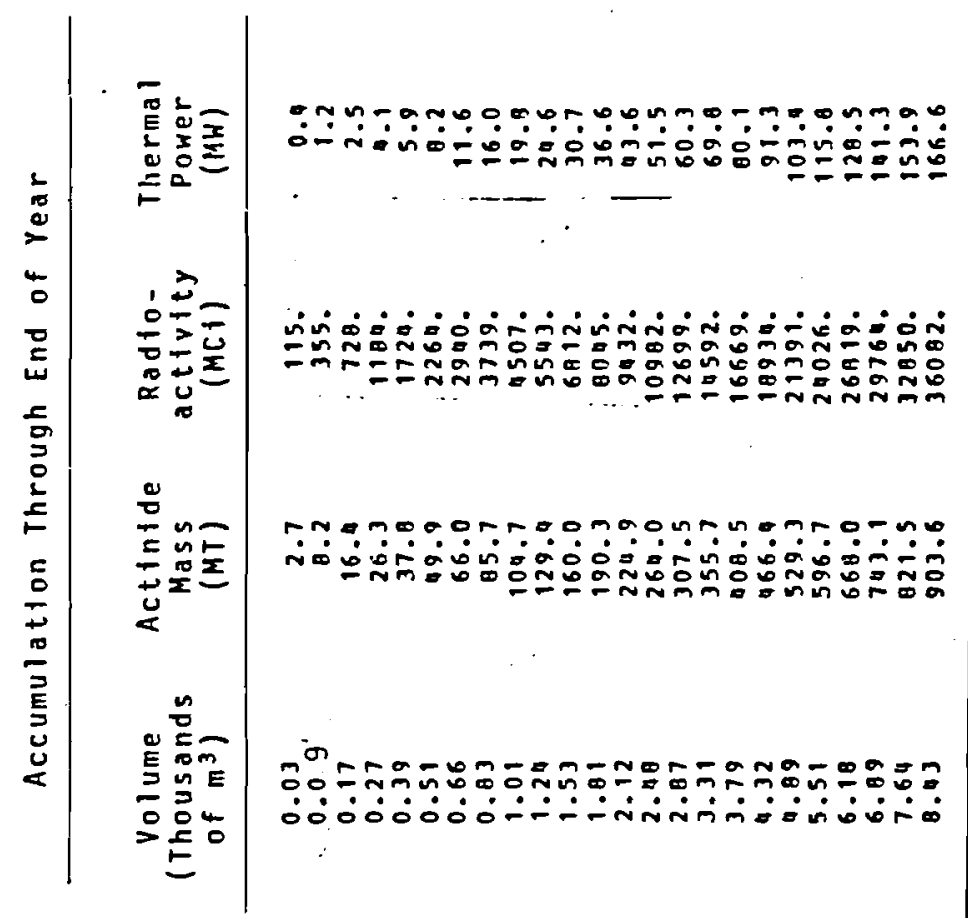

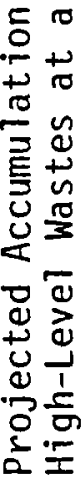

\begin{tabular}{l}
$\dot{0}$ \\
$\dot{\sigma}$ \\
$\overrightarrow{0}$ \\
\hline \multirow{E}{*}{$\mid$}
\end{tabular}

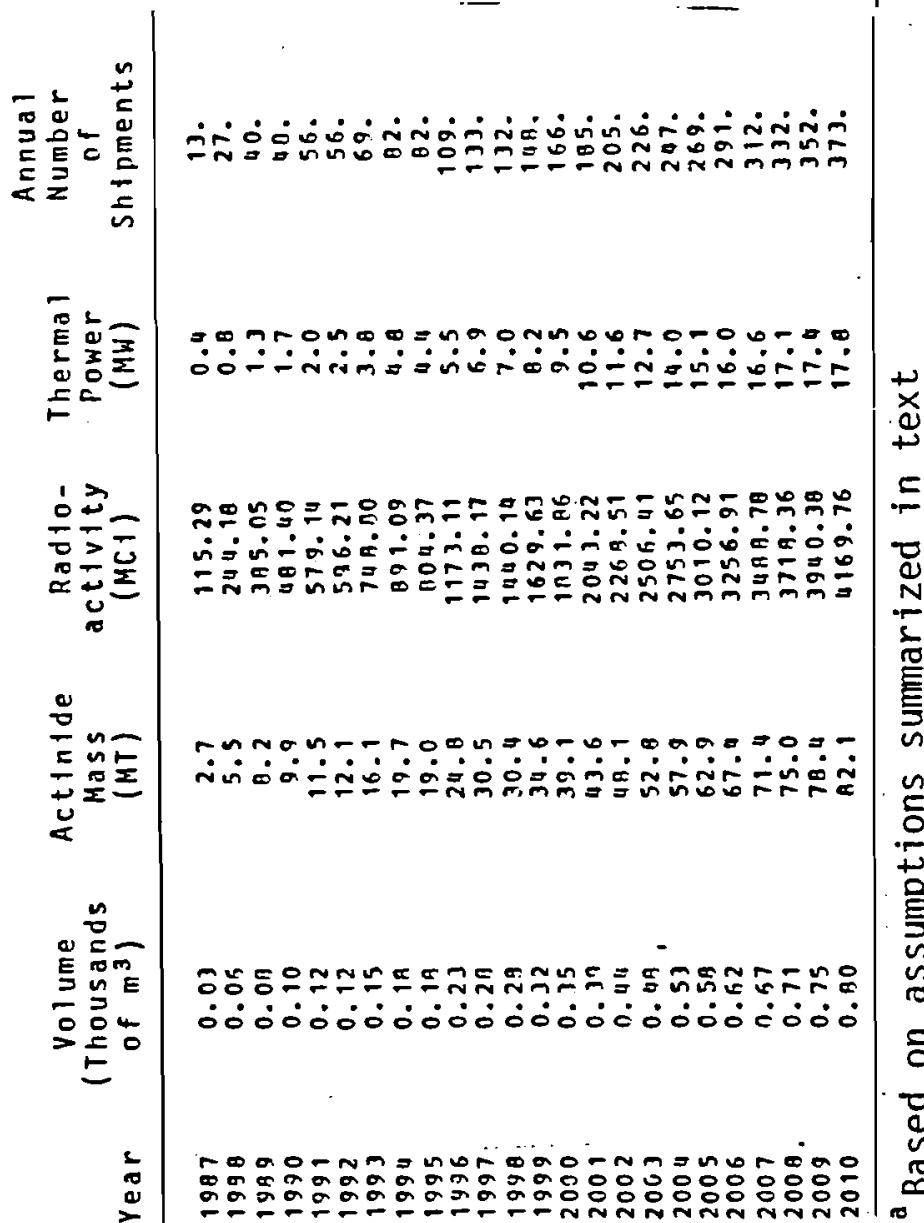


$\boldsymbol{c}$

" 
APPENDIX B

DETAILS OF CANISTER TEMPERATURE DISTRIBUTIONS 


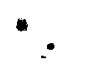


APPENDIX B

\section{DETAILS OF CANISTER TEMPERATURE DISTRIBUTIONS}

The canister temperature distributions for the borosilicate glass with fins and calcine with fins were calculated by S. W. Wilson of PNL's Engineering Physics Department using a computer code named HEAT4; this is a slightly modified version of a code, HEATING3, which was developed at Oak Ridge National Laboratory. ${ }^{(40)}$ HEAT4 includes radiation, conduction, convection, variations in physical properties with temperature, and internal fins. Table B 1 presents the results of al1 the cases which were analyzed; HEAT4 was used for Cases 1 through 57 . The maximum centerline temperature for borosilicate glass and calcine is $1472^{\circ} \mathrm{F}$. In some cases, heat generation rates of waste less than $2 \mathrm{yr}$ of age were considered. In general, these all increased the canister centerline temperature above the maximum. Also, the effect of helium in the overpack gap was found to have negligible effect on centerline temperature. In several cases an increase in canister outer wall temperature caused a supposed decrease in centerline temperature (see Cases 1 and 4 - an increase in wall temperature from 350 to $400^{\circ} \mathrm{F}$ decreased the canister centerl ine temperature from 1383 to $1364^{\circ} \mathrm{F}$ ). These discrepancies are probably caused by inaccuracies in internal fin modeling which could be corrected by a finer model, but would result in increased computer costs. A decision was made that at this stage of concept development including the uncertainty in waste disposal criteria (canister size), a more refined analysis was not warranted.

S. W. Wilson also calculated the temperature distributions for borosilicate glass waste without fins (Cases 57 through 93) using a finite difference model that is less involved than HEAT4, but still includes the variation in physical properties with temperature.

In Cases 94 through 141 calcine-al matrix is considered. The computer code used was a slightly modified form of a code (Radhot, Reference 41) 


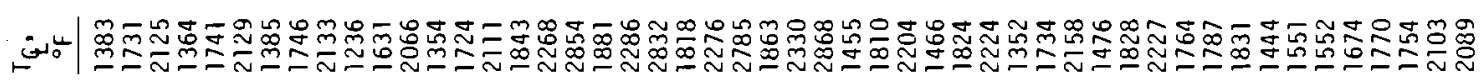

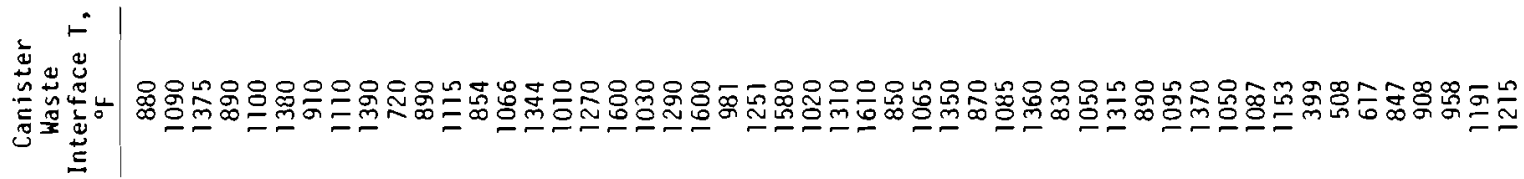
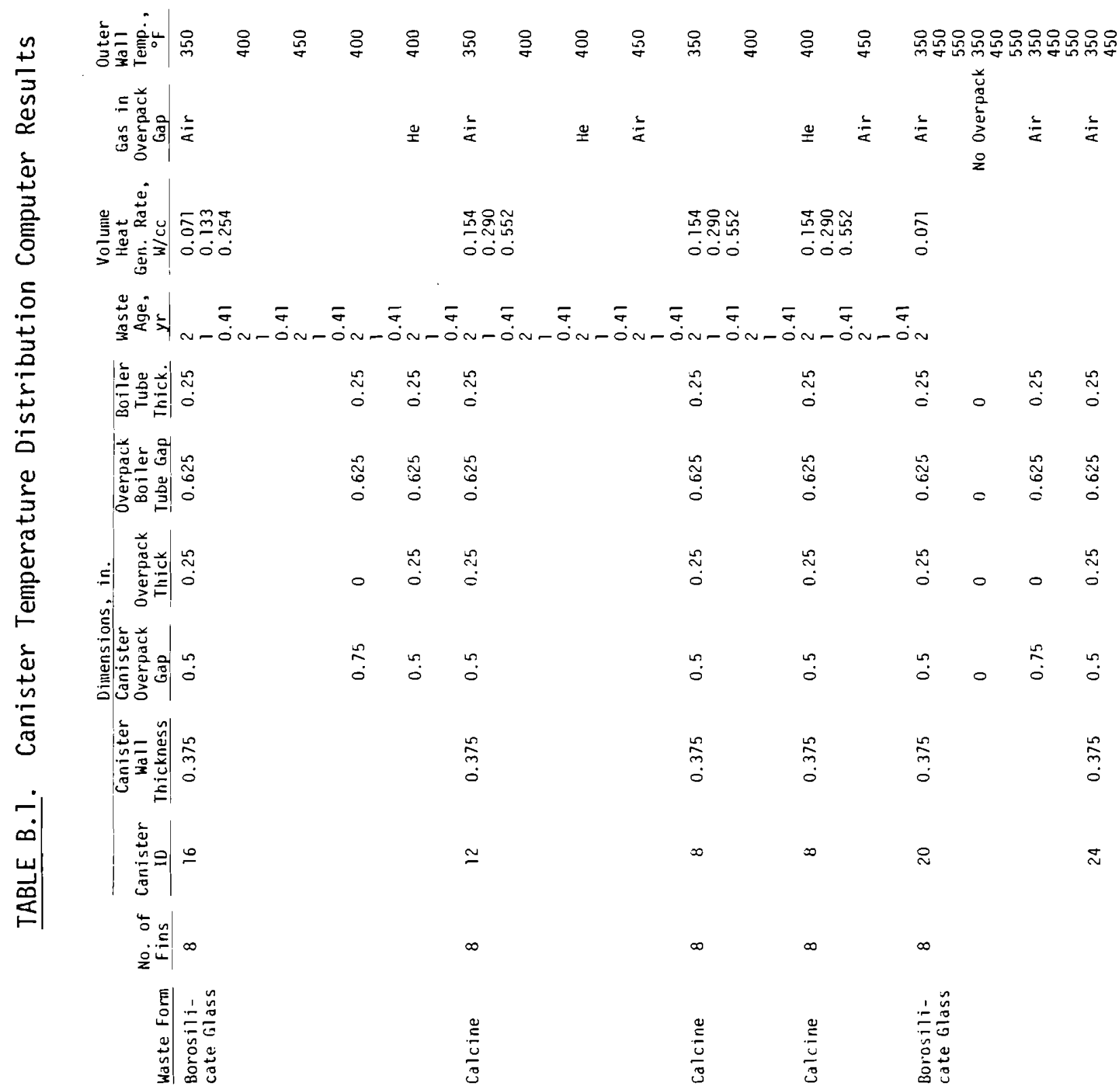

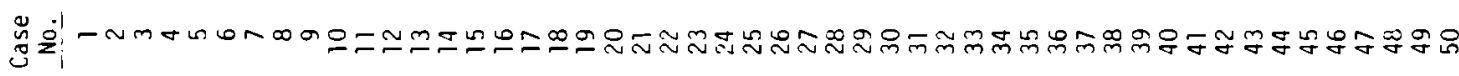




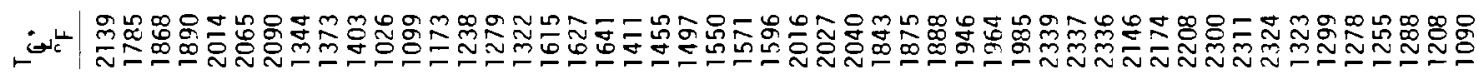

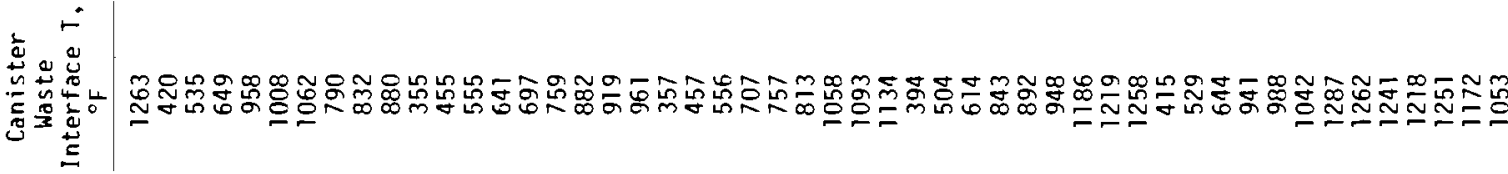

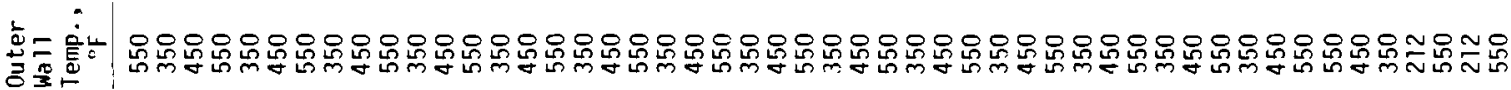

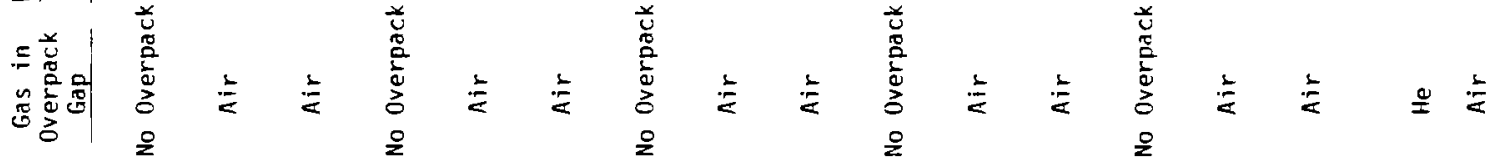

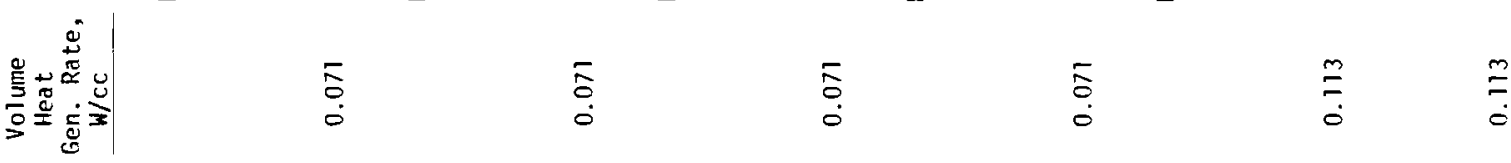

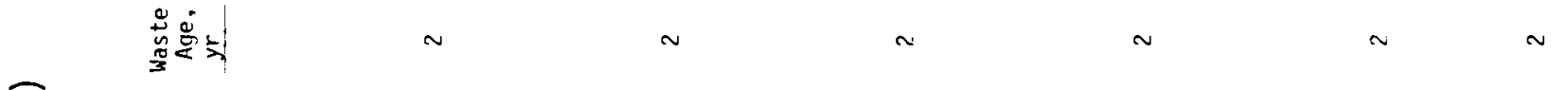

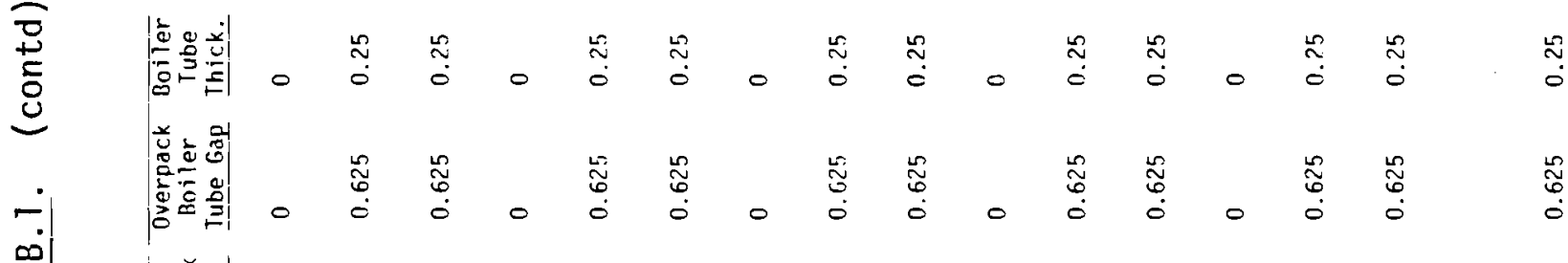

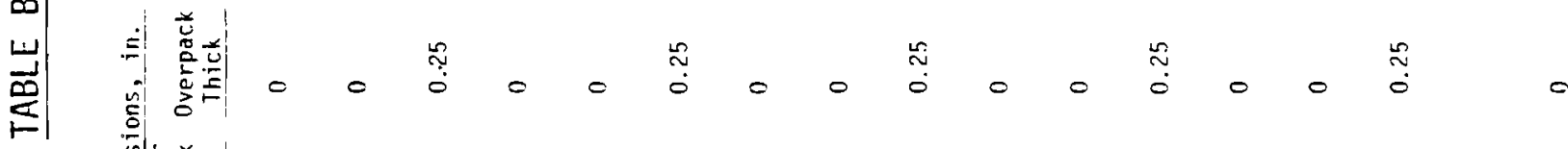

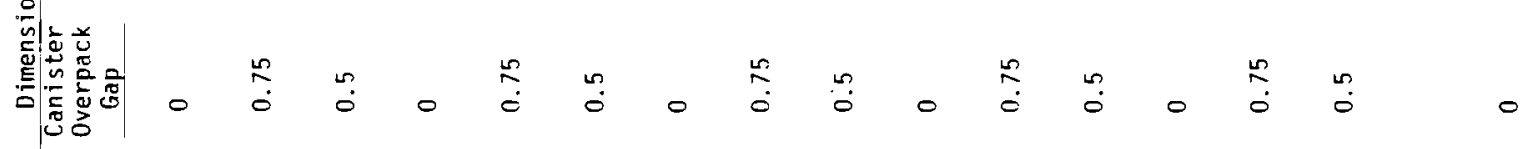

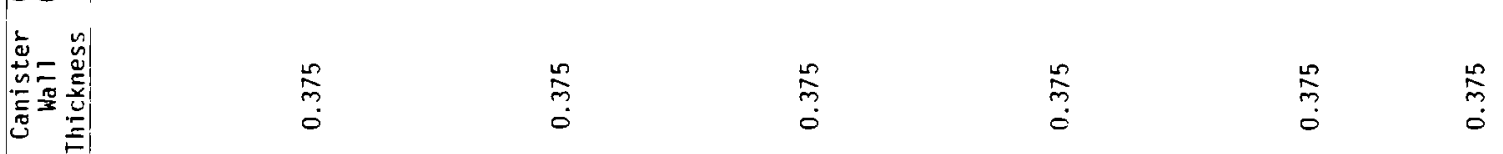

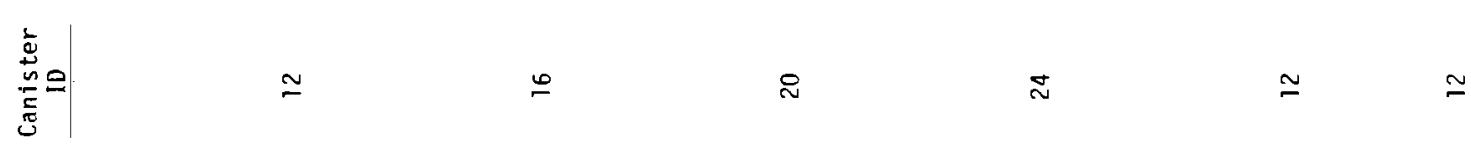

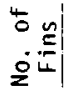
$\circ$
$\circ \quad 0$
$\circ \quad 0$

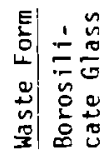

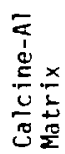

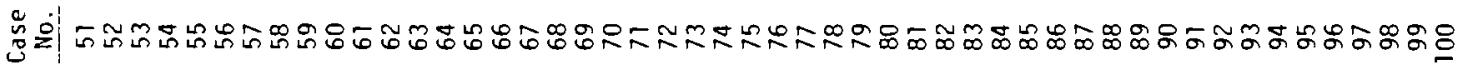


TABLE B.1. (contd)

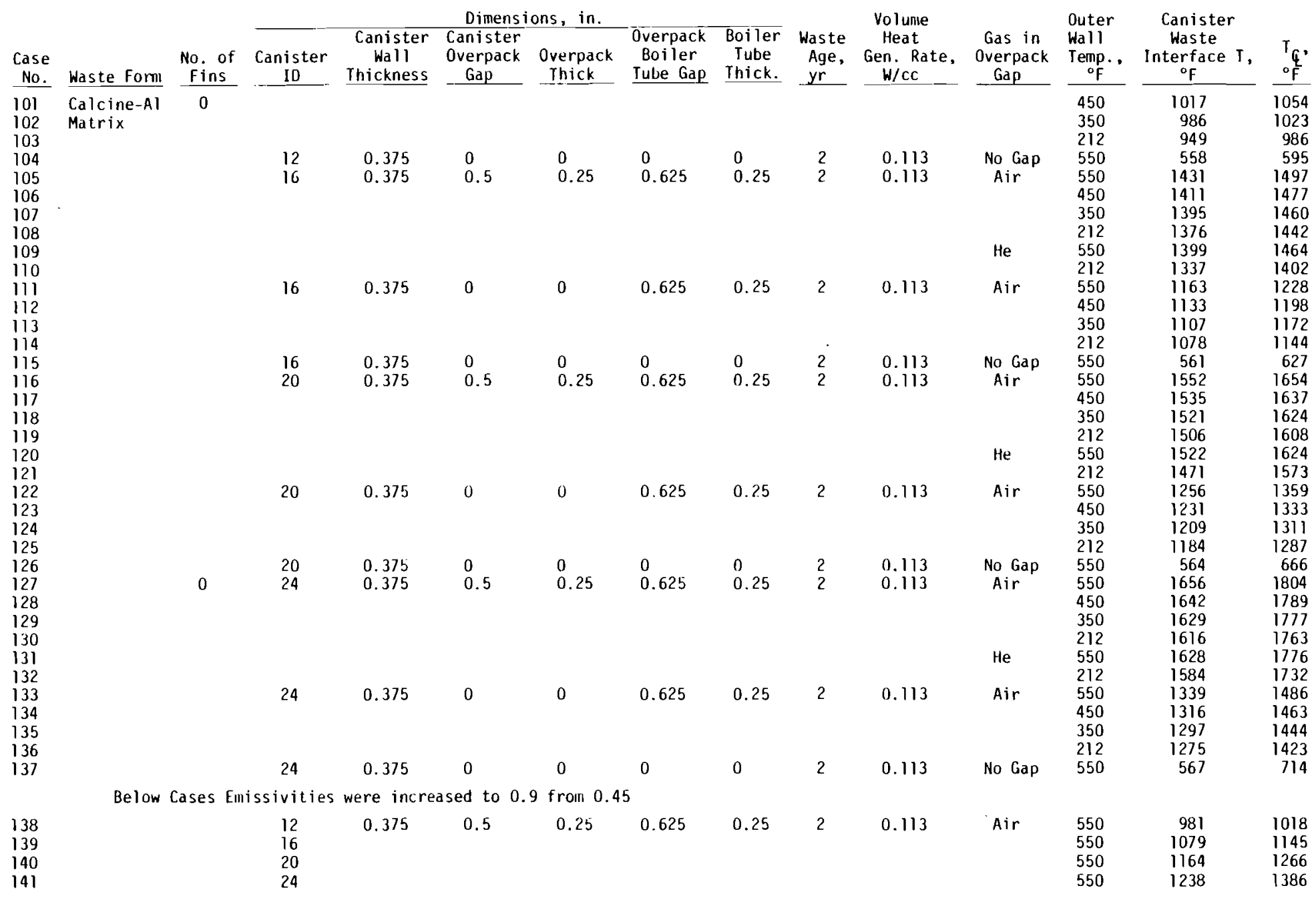


that was developed as part of PNL's "Beneficial Isotopes Utilization Program" which is funded by ERDA-NRA. The theory behind the code is presented in Reference 41. Temperature dependencies of physical properties are not included; they are not known for the matrix.

As expected, the diameter of the bare canister (calcine-al matrix) can be as large as $24 \mathrm{in}$, have a wall temperature of $550^{\circ} \mathrm{F}$, and still maintain a centerline temperature below the maximum $\left(1220^{\circ} \mathrm{F}\right)$. The addition of an overpack limits canister diameter to 16 in. With an overpack and boiler tube, helium in the overpack will limit the diameter to $12 \mathrm{in.,}$ but if the emissivities are increased to 0.9 by special treatment of all surfaces, the diameter limit would increase to $16 \mathrm{in}$. The thermal conductivity used in these calculations was $0.32 \mathrm{~W} / \mathrm{cm}^{\circ} \mathrm{C}$. When physical properties of this waste form are more certain, calculations including the temperature dependence of physical properties may be warranted, but the canister size limits may be set by disposal criteria such as salt temperature and heat loading instead of thermal conductivity. 
$\therefore$ 
APPENDIX C

DETAILS OF CAPITAL INVESTMENT 


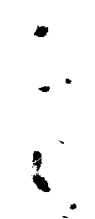


APPENDIX C

\section{DETAILS OF CAPITAL INVESTMENT}

The following cost estimates for 5-MW steam plants are provided in this Appendix:

Table C.1: Water Basin Receiving Facility

Table C.2: Hot Cell Receiving Facility

Table C.3: Boiler Facility (Concepts 1.2 and 1.4)

Table C.4: Special Equipment (Concepts 1.2 and 1.4)

Table C.5: Boiler Facility (Concept 2.2)

Table C.6: Special Equipment (Concept 2.2)

Table C.7: Sitework, Yardwork, Exhaust Fan and Filter House, Communications and Alarm 
TABLE C.1. Water Basin Receiving Facility

Description

Transport Cask Unloading Basin

Excavation

Backfil1 - Compacted

S.S. Liner

$$
\text { - Regular }
$$

Anchors

Curb Anchors, etc.

S.S. Channels

Concrete

Impact Absorber - Transfer Cask - Transport Cask

Allowance for Undeveloped Design (10\%)

Total (1973\$)

CE Plant Cost Index (August 1976)

Tota 1

Structure

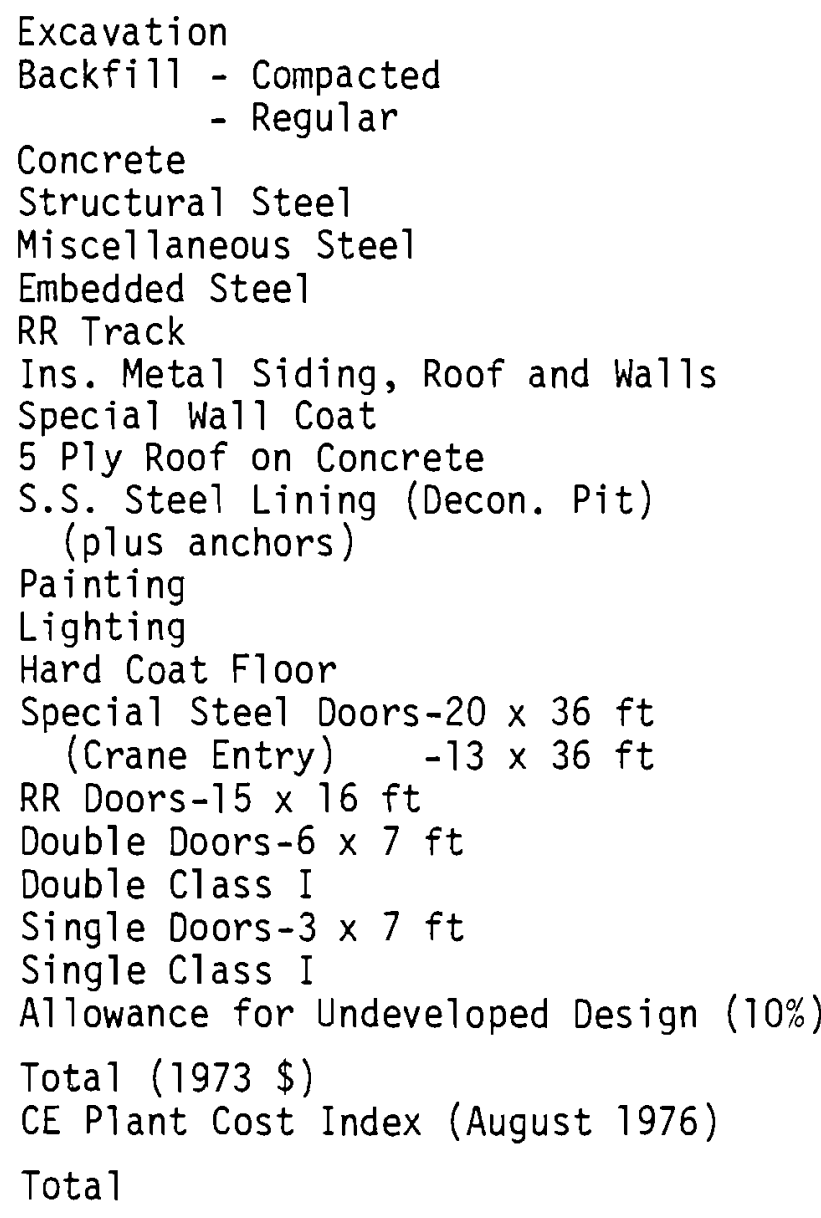

\begin{tabular}{|c|c|c|c|}
\hline Quantity & Unit Cost & \multicolumn{2}{|r|}{ Amount } \\
\hline $\begin{array}{r}330 \text { cy } \\
83 \text { cy } \\
165 \text { cy } \\
2,200 \text { sf } \\
2,5301 b \\
3,9301 b \\
8101 b \\
170 \text { cy } \\
1 \text { ea } \\
1 \text { ea }\end{array}$ & $\begin{array}{r}1.00 \\
4.50 \\
1.50 \\
30.00 \\
2.00 \\
1.00 \\
2.50 \\
140.00 \\
6,000.00 \\
15,000.00\end{array}$ & $\$$ & $\begin{array}{r}330 \\
370 \\
250 \\
66,000 \\
5,060 \\
3,930 \\
2,030 \\
23,800 \\
6,000 \\
15,000 \\
12,600\end{array}$ \\
\hline & & $\$$ & $\begin{array}{r}135,100 \\
1.35\end{array}$ \\
\hline & & $\$$ & 182,400 \\
\hline
\end{tabular}

\begin{tabular}{|c|c|c|c|c|}
\hline $\begin{array}{r}2,000 \\
830 \\
800 \\
570 \\
50 \\
12 \\
10 \\
72 \\
15,400 \\
4,700 \\
1,380 \\
350\end{array}$ & $\begin{array}{l}\text { cy } \\
\text { cy } \\
\text { cy } \\
\text { cy } \\
\text { tn } \\
\text { tn } \\
\text { tn } \\
\text { tf } \\
\text { sf }\end{array}$ & $\begin{array}{r}2.00 \\
4.50 \\
1.50 \\
130.00 \\
650.00 \\
750.00 \\
1,000.00 \\
30.00 \\
3.50 \\
2.00 \\
0.50 \\
35.00\end{array}$ & $\$$ & $\begin{array}{r}4,000 \\
3,700 \\
1,200 \\
74,100 \\
32,500 \\
9,000 \\
10,000 \\
2,220 \\
53,900 \\
9,400 \\
700 \\
12,300\end{array}$ \\
\hline $\begin{array}{r}30,000 \\
7,000 \\
7,000 \\
1\end{array}$ & $\begin{array}{l}\text { ea } \\
\text { ea } \\
\text { ea } \\
\text { ea } \\
\text { ea } \\
\text { ea } \\
\text { ea }\end{array}$ & $\begin{array}{r}0.06 \\
2.00 \\
0.50 \\
30,000.00 \\
20,000.00 \\
4,000.00 \\
500.00 \\
1,600.00 \\
300.00 \\
1,000.00\end{array}$ & & $\begin{array}{r}1,800 \\
14,000 \\
3,500 \\
30,000 \\
20,000 \\
4,000 \\
2,500 \\
3,200 \\
3,000 \\
2,000 \\
30,500 \\
\end{array}$ \\
\hline & & & & $\begin{array}{r}327,500 \\
1.35 \\
\end{array}$ \\
\hline & & & & 442, \\
\hline
\end{tabular}




\section{TABLE C.1. (contd)}

Description

Handling Equipment

Bridge Crane $125 \mathrm{~T}$

Bridge Crane $50 \mathrm{~T}$

Transfer Cask

Allowance for Undeveloped Design (10\%)

Installation (20\%)

Total (1973\$)

CE Plant Cost Index (August 1976)

Total

Process Equipment

Impact Wrench

Crane Mounted Air Hose Reel

Spray Pump and System

Spray Catch Tank $3 \mathrm{ft} \phi \times 5 \mathrm{ft}$

Suspect Waste Tank - Sparge Air

Hot Waste Tank - Sparge Air

Ion Exchange Portable

Hot Waste Pump - SS

AMV Chem. Mix Tanks

Acid Storage Tank

Pumps SS

Allowance for Undeveloped Design (10\%) Installation (20\%)

Total (1973\$)

CE Plant Cost Index (August 1976)

Total

Cooling and Electrical Equipment

Cooling Towers

Cooling Tower Pumps

Plate Type Heat Exchangers

Diesel Generator \& Dampers

Fuel 0il Tank \& Pumps

Installation (20\%)

Allowance for Undeveloped Design (10\%)

Total (1973 \$)

CE Plant Cost Index (August 1976)

Total
Quantity Unit Cost Amount

1 ea $\$ \quad 145,000 \$ 145,000$

1 ea $\quad 75,000 \quad 75,000$

1 ea $\quad 60,000 \quad 60,000$

28,000

56,000

$\$ 364,000$

1.35

$\$ 491,400$

\begin{tabular}{|c|c|c|c|}
\hline \multirow[t]{3}{*}{$\begin{array}{l}\text { ea } \\
\text { ea } \\
\text { ea } \\
\text { ea } \\
\text { ea } \\
\text { ea } \\
\text { ea } \\
\text { ea } \\
\text { ea } \\
\text { ea } \\
\text { ea }\end{array}$} & $\begin{array}{r}1,000 \\
2,000 \\
5,000 \\
1,000 \\
20,000 \\
12,000 \\
2,000 \\
1,000 \\
5,000 \\
1,000 \\
2,000\end{array}$ & $\$$ & $\begin{array}{r}1,000 \\
2,000 \\
5,000 \\
1,000 \\
20,000 \\
12,000 \\
2,000 \\
1,000 \\
5,000 \\
1,000 \\
2,000 \\
5,200 \\
10,400 \\
\end{array}$ \\
\hline & & $\$$ & $\begin{array}{r}67,600 \\
1.35 \\
\end{array}$ \\
\hline & & 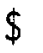 & 91 , \\
\hline
\end{tabular}

2 ea

6,000

2,000

2,500

50,000

4,000

$\begin{array}{r}12,000 \\ 4,000 \\ 5,000 \\ 50,000 \\ 4,000 \\ 15,000 \\ 9,000 \\ \hline 99,000 \\ 1.35 \\ \hline \quad 133,700\end{array}$ 
TABLE C.1. (contd)

\section{Description}

Waste Handling Equipment

Waste Compactor

Cement Hopper

Fill Station

Roller Conveyor

Installation and Undeveloped Design

$(30 \%)$

Total (1973\$)

CE Plant Cost Index (August 1976)

Total

Receiver Facility and Cooling Total

Electrical, Pipework, Instrumentation, $H V$ and $A C$ Equipment and Ductwork
Quantity Unit Cost Amount

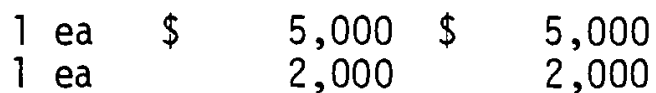

1 ea

1 ea 2,000

15,000 2,000 15,000

7,000

$\$ 29,000$ 1.35

$\$ 39,200$

$\$ 1,380,100$

1.44

$\$ 1,987,000$ 
TABLE C.2. Hot Ce11 Receiver Facility

Description

Hot Cell Structure

Concrete High Density

Concrete-Class I

S.S. Liner

Wall Finish

Allowance for Undeveloped Design (10\%)

Total (1973 \$)

CE Plant Cost Index (August 1976)

Total

Hot Cell Handling Equipment

Crane and Controls

Misc. Small Tools

Access Port Cover

Shielded Door-Crane Repair

Shielded Door-Personnel

Transfer Cask Port $\left(3^{\prime} \phi\right)$

Access Hatch $\left(10^{\prime} \times 14^{\prime} \times 4^{\prime}\right)$

Patch Pass Thru

Equipment Pass Thru

Al lowance for Undeveloped Design (10\%)

Instâllation $(20 \%)$

Total (1973 \$)

CE Plant Cost Index (August 1976)

Total

Waste Handling Equipment

Waste Compactor

Cement Hopper

Fill Station

Roller Conveyor

Installation and Undeveloped Design (30\%)

Total (1973\$)

CE Plant Cost Index (August 1976)

Total
Quantity Unit Cost Amount

\begin{tabular}{|c|c|c|c|}
\hline \multirow[t]{2}{*}{$\begin{array}{r}16 \mathrm{cy} \\
1,586 \mathrm{cy} \\
830 \mathrm{sf} \\
4,100 \mathrm{sf}\end{array}$} & \multirow[t]{3}{*}{$\begin{array}{r}420.00 \\
145.00 \\
40.00 \\
2.00\end{array}$} & $\$$ & $\begin{array}{r}6,700 \\
230,000 \\
33,200 \\
8,200 \\
28,000\end{array}$ \\
\hline & & $\$$ & $\begin{array}{r}306,100 \\
1.35 \\
\end{array}$ \\
\hline & & $\$$ & 413 \\
\hline
\end{tabular}

1 ea

66,000

30,000

2,000

7,000

18,000

3,000

19,000

15,000

17,000

18,000

36,000

$\$ 231,000$

1.35

$\$ 312,000$

1 ea

1 ea

1 ea

1 ea
$\$ \quad 5,000$

2,000

2,000

15,000

7,000

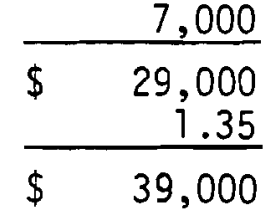


TABLE C.2. (contd)

Description

Hot Cell Process and Other Ecuipment

Shielded Windows

Manipulators

Manipulator Cart

Impact Wrench

Crane Mounted Air Hose Reel

TV Systems

TV Cable Reels on Crane

Periscope

Waste Compactor

Spray Pump and System

Lead Spray Chamber

Spray Catch Tank $3^{\prime} \phi \times 5^{\prime}$

Suspect Waste Tank - Sparge Air

Hot Waste Tank - Sparge Air

Ion Exchange Portable

Hot Waste Pump - SS

AMV Chem. Mix Tanks

Acid Storage Tank

Pumps SS

Allowance for Undeveloped Design (10\%)

Installation (20\%)

Total (1973\$)

CE Plant Cost Index (August 1976)

Tota 1

Welding Equipment

Welding Head-Remote

Canister Positioner

Automatic Welding Controls

Helium Leak Test

Ultrasonic Test

Decasking Equipment

Installation and Undeveloped Design (30\%)

Total (August 1976)
Quantity Unit Cost Amount

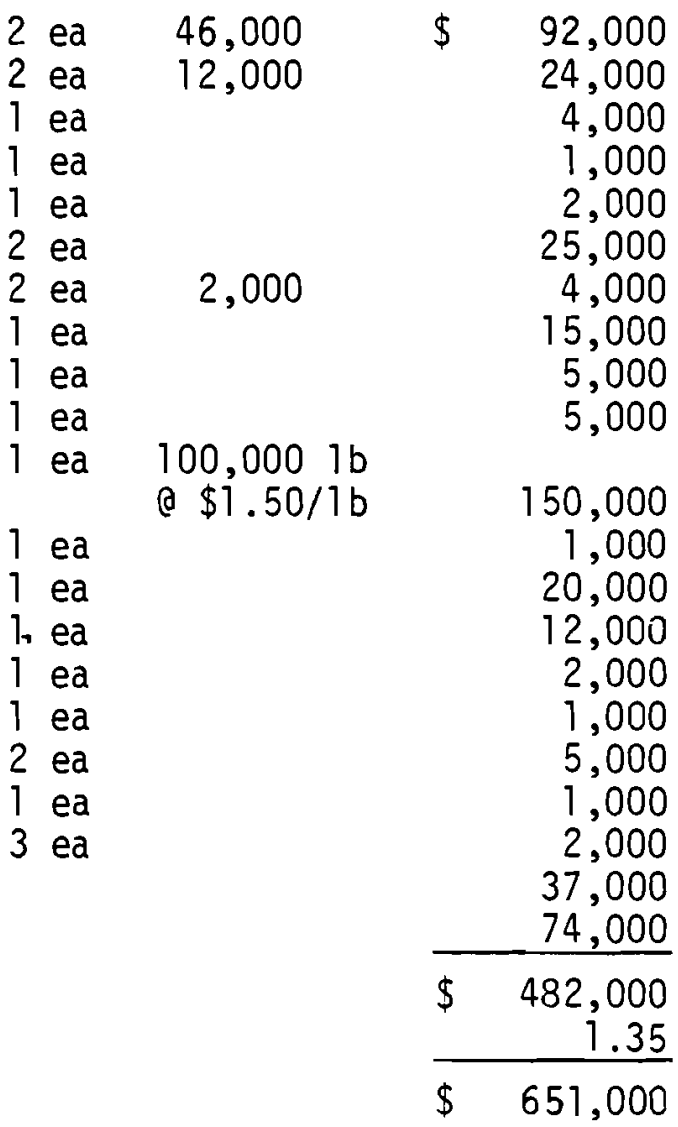

1 ea

1 ea

1 ea

1 ea

1 ea

1 ea
$\$ 50,000$

80,000

50,000

20,000

20,000

20,000

72,000

$\$ 312,000$ 
TABLE C.2. (contd)

Description

Structure

Excavation

Compacted Backfill

Backfill (Regular)

Concrete (al1 costs)

Concrete Block

Structural Steel

Miscellaneous Steel

Embedded Steel

Transfer Track

RR Track

Metal Deck w/5 ply Roof

5-Ply Roof on Concrete

Ins. Metal Siding

Pedestal Floor

Glass Partition

Doors: RR Rollup $15 \times 16 \mathrm{ft}$

Rollup $8 \times 11 \mathrm{ft}$

Rollup $12 \times 12 \mathrm{ft}$

Rollup $12 \times 16 \mathrm{ft}$

Single $3 \times 7 \mathrm{ft}$

Single Class I $3 \times 7 \mathrm{ft}$

Double $6 \times 7 \mathrm{ft}$

Double Class I $6 \times 7 \mathrm{ft}$

Special Steel Doors $13 \times 16 \mathrm{ft}$

Elevator

Plumbing

Painting

Lighting

Ceramic Tile

Vinyl Tile Floor

Hard Coat Floor

Suspended Ceiling

Allowance for undeveloped design (10\%)

Total

CE Plant Cost Index (August 1976)

Tota 1

Cooling and Electrical Equipment ${ }^{(a)}$

Quantity Unit Cost Amount

$10,000 \mathrm{cy}$

$4,000 \mathrm{cy}$

3,500 cy

3,000 cy

$5,000 \mathrm{sf}$

$150 \mathrm{tn}$

$16 \mathrm{tn}$

13 tn

$140 \mathrm{tf}$

$72 \mathrm{tf}$

7,450 sf

11,750 sf

$10,400 \mathrm{sf}$

$350 \mathrm{sf}$

285 sf

1 ea

4 ea

1 ea

1 ea

40 ea

1 ea

14 ea

1 ea

2 ea

1 ea

18 un

$1,053,000$

$25,500 \mathrm{sf}$

$1,250 \mathrm{sf}$

$1,290 \mathrm{sf}$

$15,550 \mathrm{sf}$

$2,800 \mathrm{sf}$
2.00
4.50
1.45
130.00
3.00
650.00
750.00
$1,000.00$
15.00
30.00
2.50
0.50
3.50
6.00
6.50
$4,000.00$
600.00
$1,000.00$
$1,500.00$
250.00
$1,000.00$
400.00
$1,600.00$
$9,000.00$
$50,000.00$
750.00
0.06
3.00
2.50
1.00
0.50
1.50
20,000

18,000

5,000

390,000

15,000

97,500

12,000

13,000

2,100

2,200

18,600

5,900

36,400

2,100

1,900

4,000

2,400

1,000

1,500

10,000

1,000

5,600

1,600

18,000

50,000

13,500

65,000

76,500

3,100

1,300

7,800

4,200

81,000

$\$ 887,200$ 1.35

$\$ 1,19,00$

$\$ 134,000$

(a) See Table C-1. 
TABLE C.2. (contd)

Description

Quantity Unit Cost Amount

Handling Equipment - Multiple Canister Shipments

Bridge Crane $125 T$

Shipping Cask Transporter

Shipping Cask Lift Table

Shipping Cask Port (for Hot Ce11, 7' $\phi$ )

Transfer Cask

Transfer Cask Lift Table

Transfer Cask Car

Allowance for Undeveloped Design (10\%)

Installation (20\%)

Total (1973\$)

CE Plant Cost Index (August 1976)

Total
1 ea

1 ea

1 ea

1 ea

1 ea

1 ea

1 ea
$\$ \quad 145,000$

11,000

97,000

10,000

60,000

50,000

40,000

41,000

83,000

$\$ 537,000$

1.35

$\$ 725,000$

Electrical

Pipework

Instrumentation

$10 \%$

$15 \%$

$15 \%$

$44 \%=1.44$ factor

HV and AC Equipment (and Ductwork)

$4 \%$

$$
\begin{aligned}
\text { Receiver Facility and Cooling Total } & =3,784,000 \times 1.44 \\
& =5,449,000
\end{aligned}
$$




\section{TABLE C.3. Boiler Facility (Concepts 1.2 and 1.4)}

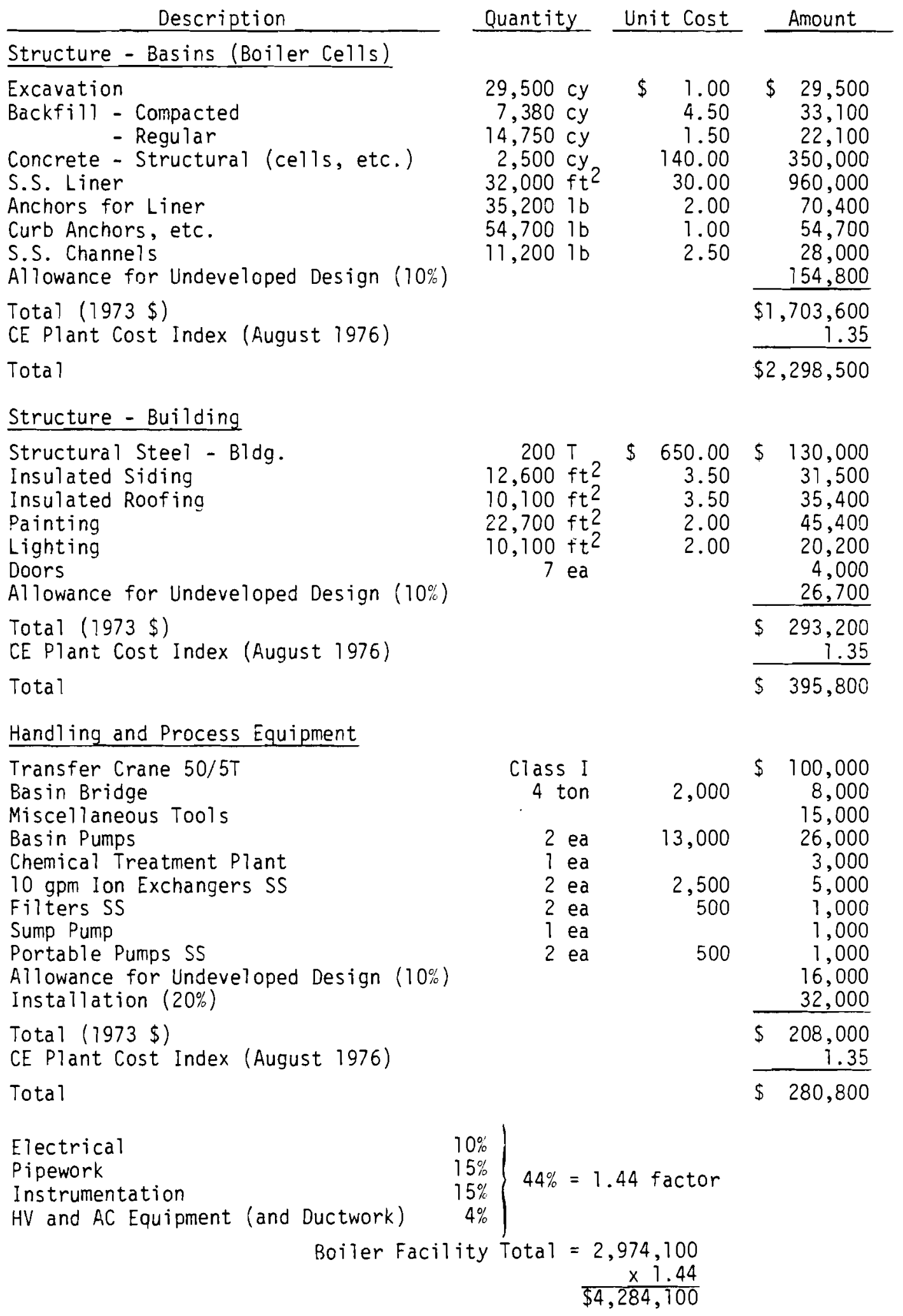


TABLE C.4. Special Equipment (Concepts 1.2 and 1.4)

Description

Stainless Steel Equipment

Boilers

Shielding Tanks

A1lowance for Undeve1oped Design (10\%)

Tota1 (August $1976 \$$ )

Carbon Stee1 Equipment

Boilers

Shielding Tanks

A1lowance for Undeveloped Design (10\%)

Total (August $1976 \$$ )
Quantity Unit Cost Amount

$$
\begin{array}{rrr}
20 \text { ea } & \$ 170,000 & \$ 3,400,000 \\
20 \text { ea } & 41,000 & 820,000 \\
& & 422,000 \\
\hline & & \$ 4,642,000
\end{array}
$$

20 ea $\$ 32,000$

20 ea

13,000

$\$ 640,000$

260,000

90,000

$\$ 990,000$ 
TABLE C.5. Boiler Facility (Concept 2.2)

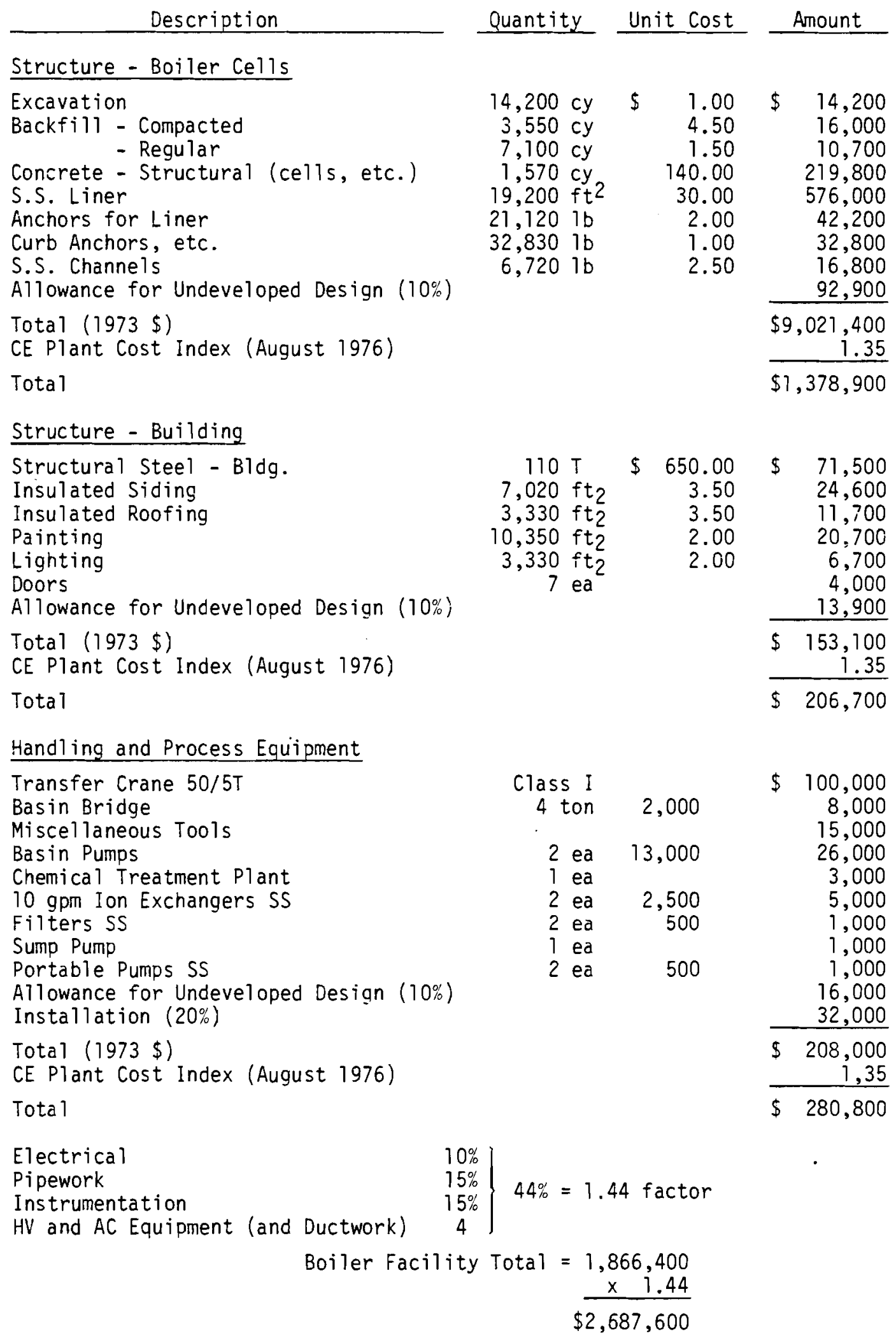


TABLE C.6. Special Equipment (Concept 2.2)

\begin{tabular}{|c|c|c|c|}
\hline Description & Quantity & Unit Cost & Amount \\
\hline $\begin{array}{l}\text { Pressure Heads } \\
\text { Storage Racks } \\
\text { Secondary Heat Exchanger } \\
\text { Allowance for Undeveloped Design (10\%) }\end{array}$ & $\begin{array}{r}20 \text { ea } \\
14,4001 \mathrm{~b}\end{array}$ & $\begin{array}{r}\$ 10,000 \\
3.70\end{array}$ & $\begin{array}{r}200,000 \\
53,000 \\
66,000 \\
32,000 \\
\end{array}$ \\
\hline Total (1976\$) & & & 351,000 \\
\hline
\end{tabular}


TABLE C.7. Sitework, Yardwork, Exhaust Fan and Filter House, Communications and Alarm

Description Quantity Unit Cost Amount

Sitework:

Site Clearing, Grading

Clear Brush

Stockpile Top Soil

Grade - Cut

- Compacted Fill

Spread Top Soi 1

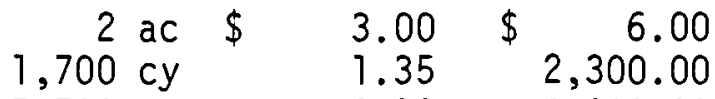

7,700 cy $\quad 0.80 \quad 6,200.00$

$\begin{array}{lll}7,700 \mathrm{cy} & 1.00 \quad 7,700.00\end{array}$

Total

0.95

$1,600.00$

$\$ 18,400.00$

Yard Lighting

Fence

Parking Lot

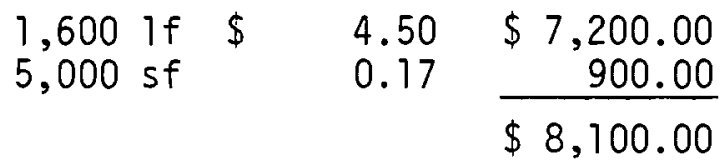

Total

Roads, Parking, and Sidewa $7 \mathrm{ks}$

$12 \mathrm{ft}$ Road (Black Top)

$4 \mathrm{ft}$ Shoulder

$4 \mathrm{ft} \times 4 \mathrm{in}$. Concrete Sidewalk

Parking Lot

Total

\begin{tabular}{lllr}
530 sy & $\$$ & 5.25 & $\$ 2,800.00$ \\
360 sy & & 2.00 & 700.00 \\
800 sf & & 1.50 & $1,200.00$ \\
580 cy & & 4.50 & $2,600.00$ \\
\hline & & & $\$ 7,300.00$
\end{tabular}

Fencing

$8 \mathrm{ft}$ Chain Link

Motorized Gates

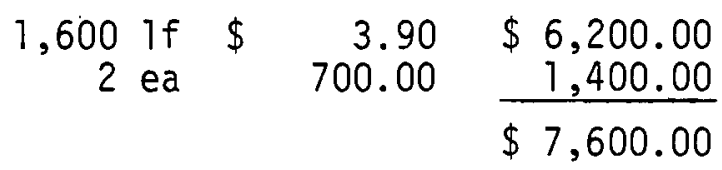

Total

Plant Railroad

90 in. Track

Turnout

500 tf $\$ 25.00$

$\$ 12,500.00$

1 ea $3,000.00 \quad 3,000.00$

Total

$\$ 75,500.00$

Soil - Stabilize and Sterilize

2 ac $\$ 1,700.00 \$ 3,400.00$

Total (1973 \$)

CE Plant Cost Index (August 1976)

$\$ 60,300.00$

Total Sitework 1.35

$\$ 81,000.00$ 
TABLE C.7. (contd)

Description

Yardwork:

Raw Water Pumps

(Installation)

Water Storage Tank (250,000 ga 1)

Fire Water Pump

Installation

Emergency Water Class I -

20 in. Gravel Packed Well $350 \mathrm{ft}$

6 in. Deep Well Pumps

Installation

Septic Tank

Waste Water - Pond Excavation and Compacted Fill

Pipework - Water Main 8 in.

Fire Main 12 in.

Domestic Water

Emergency Water 3 in. class I

Sanitary Sewer

Waste 6 in.

Storm Drain 18 in.

Electrical -

Substation

(Labor)

Poleline and General Distribution

(Labor)

Allowance for Undeveloped Design (10\%)

Total (1973\$)

CE Plant Cost Index (August 1976)

Total

Exhaust Fan and Filter House

Structure
Quantity Unit Cost Amount
2 ea $\$ 1,000.00$

$60 \mathrm{hr}$

1 ea

1 ea

$50,000.00$

$15,000.00$

2 ea

2 ea

$320 \mathrm{hr}$

1 ea

$3,000 \mathrm{cy}$

$1,000 \mathrm{ft}$

$200 \mathrm{ft}$

$100 \mathrm{ft}$

$1,000 \mathrm{ft}$

$750 \mathrm{ft}$

$750 \mathrm{ft}$

$100 \mathrm{ft}$

1 ea

$1,200 \mathrm{hr}$

$500 \mathrm{hr}$

3.00

17.00

24.35

9.00

10.10

5.60

12.55

14.00

15.00

$$
\begin{array}{r}
50.00 \\
4,000.00 \\
15.00 \\
4,200.00
\end{array}
$$

15.00

$$
\begin{aligned}
& \frac{20,600.00}{\$ 396,300.00} \\
& 1.35
\end{aligned}
$$
$31,000.00$ $7,500.00$

$\begin{array}{rrrr}1,400 \text { cy } & \$ & 2.00 & \$ 2,800.00 \\ 900 \text { cy } & 5.00 & 4,500.00 \\ 35 \text { cy } & 4.50 & 200.00 \\ 170 \text { cy } & 130.00 & 22,100.00 \\ 1 \text { ea } & 1,000.00 & 7,000.00 \\ 1 \text { ea } & 200.00 & 200.00 \\ 1,500 \text { sf } & 1.25 & 1,900.00 \\ 20 \text { sq } & 50.00 & 1,000.00 \\ & & & 1,000.00\end{array}$


TABLE C.7. (contd)

Description

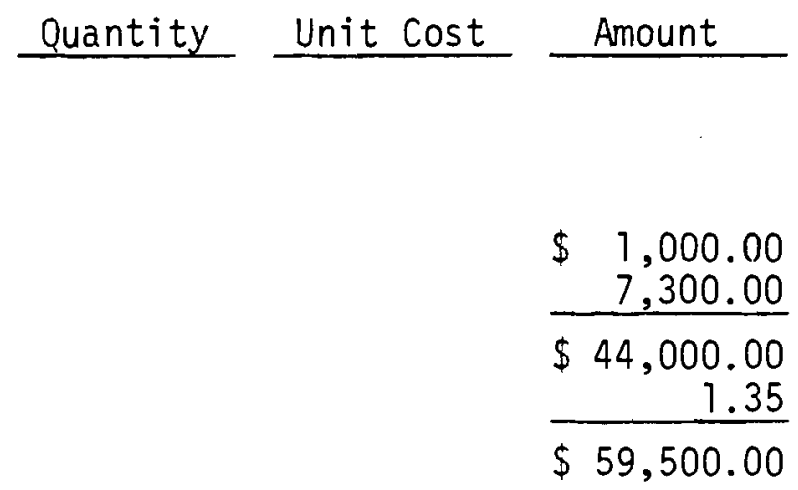

Exhaust Fan and Filter House (contd)

Structure (contd)

Miscellaneous Metal

Allowance for Undeveloped Design (20\%)

Total (1973\$)

CE Plant Cost Index (August 1976)

Total

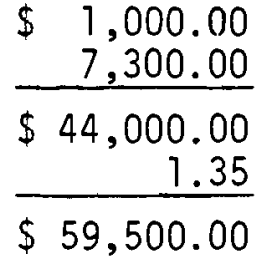

Equipment

Fan - $2700 \mathrm{cfm}$

Filters

Fan - 24,000 cfm

Fan - $6000 \mathrm{cfm}$

Filters (for $24,000 \mathrm{cfm}$ ) (for $6,000 \mathrm{cfm}$ )

Tornado Dampers

Installation (20\%)

Allowance for Undeveloped Design (10\%)

Total (1973\$)

CE Plant Cost Index (August 1976)

$\begin{array}{rr}1 \text { ea } & \$ 1,000.00 \\ 1 \text { set } & 700.00 \\ 1 \text { ea } & 5,600.00 \\ 1 \text { ea } & 1,400.00 \\ 1 \text { ea } & 12,200.00 \\ 1 \text { ea } & 4,000.00 \\ 2 \text { ea } & 1,000.00\end{array}$

$\$ 1,000.00$

700.00

$5,600.00$

$1,400.00$

$12,200.00$

$4,000.00$

$1,000.00$

$5,200.00$

$2,600.00$

$\$ 33,700.00$

1.35

$\$ 45,500.00$

Total

Ductwork

Excavation

Backfill

42 in. $\phi 3 / 8$ in. Steel

$250 \mathrm{cy}$

$200 \mathrm{cy}$

2.00

5.00

$\$ 500.00$

$1,000.00$

30 in. $\phi$

42 in. $\phi$

48 in. $\phi$

54 in. $\phi$

$36,0001 \mathrm{~b} \quad 1.00 \quad 36,000.00$

Al lowance for Undeveloped Design (10\%)

Total (1973\$)

CE Plant Cost Index (August 1976)

Totàl
$3,800.00$

$\$ 41,300.00$

1.35

$\$ 55,800.00$ 
TABLE C.7. (contd)

\begin{tabular}{|c|c|c|c|}
\hline Description & Quantity & Unit Cost & Amount \\
\hline \multicolumn{4}{|l|}{ Stack and Monitor Room } \\
\hline $\begin{array}{l}\text { Excavation } \\
\text { Backfill } \\
\text { Concrete } \\
\text { Door } 3 \times 7 \mathrm{ft} \\
\text { Lights } \\
5 \text {-Ply Roof } \\
\text { Steel Stack } \\
\text { Allowance for Undeveloped Design }(10 \%)\end{array}$ & $\begin{aligned} 510 \mathrm{cy} \\
330 \mathrm{cy} \\
70 \mathrm{cy} \\
1 \mathrm{ea} \\
120 \mathrm{sf} \\
120 \mathrm{sf} \\
13 \text { ton }\end{aligned}$ & $\begin{array}{r}2.50 \\
5.00 \\
130.00 \\
200.00 \\
1.70 \\
0.50 \\
1,500.00\end{array}$ & $\begin{array}{r}\$ 1,300.00 \\
1,600.00 \\
9,100.00 \\
200.00 \\
200.00 \\
100.00 \\
19,500.00 \\
3,200.00 \\
\end{array}$ \\
\hline $\begin{array}{l}\text { Total (1973 \$) } \\
\text { CE Plant Cost Index (August 1976) }\end{array}$ & & & $\begin{array}{r}\$ 35,200.00 \\
1.35 \\
\end{array}$ \\
\hline Total & & & $\$ 47,500.00$ \\
\hline Total Exhaust Fan and Filter House & & & $\$ 208,300.00$ \\
\hline \multicolumn{4}{|l|}{ Communications and Alarm } \\
\hline $\begin{array}{l}\text { Annunciation System } \\
\text { Fire Alarm } \\
\text { Plant Protection Video } \\
\text { Watchmans Key System } \\
\text { Intercommunications } \\
\text { Allowance for Undeveloped Design }(10 \%)\end{array}$ & 5 ea & $\$ 10,000.00$ & $\begin{array}{r}2,000.00 \\
20,000.00 \\
50,000.00 \\
2,500.00 \\
5,000.00 \\
8,000.00 \\
\end{array}$ \\
\hline $\begin{array}{l}\text { Total (1973 \$) } \\
\text { CE Plant Cost Index (August 1976) }\end{array}$ & & & $\begin{array}{r}\$ 87,500.00 \\
1.35 \\
\end{array}$ \\
\hline Total & & & $\$ 118,100.00$ \\
\hline
\end{tabular}




\section{APPENDIX D}

SPECIAL EQUIPMENT DESIGN AND COST 


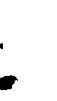


APPENDIX D

\section{SPECIAL EQUIPMENT DESIGN AND COST}

\section{CONCEPT 2 - SECONDARY HEAT EXCHANGERS}

These 6-MW heat exchangers are designed to produce $350^{\circ} \mathrm{F}$ saturated steam from $250^{\circ} \mathrm{F}$ liquid by condensing 400,450 , or $550^{\circ} \mathrm{F}$ saturated steam. The design is based on the information in Kern ${ }^{(42)}$ and costs were obtained from Peters and Timmerhaus. (35) A conservative factor of two was used to increase the area from the design equations. The results are:

\begin{tabular}{|c|c|c|c|c|c|c|c|}
\hline $\begin{array}{l}\text { Condensate } \\
\text { Temp, }{ }^{\circ} \mathrm{F}\end{array}$ & $\begin{array}{l}\text { Tube Dia, } \\
\text { in. } \\
\end{array}$ & $\begin{array}{l}\text { Shell Dia, } \\
\text { in. }\end{array}$ & $\begin{array}{l}\text { No. of } \\
\text { Tubes }\end{array}$ & $\begin{array}{l}\text { Tube } \\
\text { Length }\end{array}$ & $\begin{array}{l}\text { No. of } \\
\text { Passes }\end{array}$ & $\begin{array}{c}\text { Area, } \\
\mathrm{ft}{ }^{2} \\
\end{array}$ & $\begin{array}{l}\text { Cost, } \\
1976 \$ \\
\end{array}$ \\
\hline 400 & $3 / 4$ & 36 & 824 & 16 & 2 & 2590 & 66,000 \\
\hline 450 & $3 / 4$ & 33 & 600 & 12 & 2 & 1310 & 46,000 \\
\hline 550 & $3 / 4$ & 22 & 285 & $i 2$ & 2 & 670 & 30,000 \\
\hline
\end{tabular}

The advantage in cost reduction of the exchangers as the condensate temperatures (canister boiler temperatures) increases would have a relatively minor influence on total plant cost when the potential increase in boiler head cost is considered (higher boiler pressure at higher temperatures). The cost of the exchanger for the $400^{\circ} \mathrm{F}$ condensate was used in all Concept 2 cost estimates.

CONCEPT 2 - REMOVABLE PRESSURE HEADS

The thickness of the removable pressure heads of Concept 2 were estimated by use of the design equations for ellipsoidal heads: ${ }^{(43)}$

$$
t=\frac{P D}{2 S E-0.2 P}
$$

where $t=$ minimum wall thickness, in.

$P=$ maximum allowable internal pressure, psig

$D=$ inside diameter of major axis, in.

$S=$ maximum allowable working stress, psi

$E=$ efficiency of joints, $\%$ 
The pressure used was $350 \mathrm{psig}$ (corresponds to $430^{\circ} \mathrm{F}$ saturated steam), and the working stress was 12,000 psi (corresponds to $750^{\circ} \mathrm{F}$ carbon stee 1 ). The material of construction was taken as stainless steel clad carbon steel since the internal surface would be the only side which could come in contact with radioactive material. The head size and costs are presented in Table D.1. These were provided by Lukens Steel Co., Burlingame, CA.

\section{TABLE D.1. Removable Pressure Head Costs}

\begin{tabular}{|c|c|c|c|c|c|c|}
\hline $\begin{array}{c}\text { Concept } \\
\text { No. }\end{array}$ & $\begin{array}{c}\text { Inside } \\
\text { Dia, in. }\end{array}$ & $\begin{array}{c}\text { Thickness, } \\
\text { in. }\end{array}$ & Quantity & $\begin{array}{c}\text { Flange } \\
\text { Length, in. }\end{array}$ & $\begin{array}{l}\text { Shipping } \\
\text { Wt, } 1 \mathrm{~b}\end{array}$ & $\begin{array}{l}\text { Price, ea., } \\
1976 \$ \\
\end{array}$ \\
\hline $2.3,2.7^{(a)}$ & 78 & $13 / 8$ & 20 & 2 & 2,984 & 5,000 \\
\hline $2.8^{(a)}$ & 84 & $11 / 2$ & 20 & 2 & 4,271 & 6,700 \\
\hline $\begin{array}{l}2.1,2.2^{(a)} \\
2.5\end{array}$ & 96 & $13 / 4$ & 27 & 2 & 6,333 & 10,000 \\
\hline $2.4^{(b)}$ & 120 & $21 / 8$ & 20 & 2 & 12,577 & 18,000 \\
\hline $2.6^{(c)}$ & 168 & 2.4 & 14 & 2 & 32,955 & 55,000 \\
\hline
\end{tabular}

(a) 20\% Nom. Clad, Type 304 to Spec. A-254 with shear tests, on backing of ASTM A-36.

(b) $15 \%$ Max. Clad, materials same as (a).

(c) $3 / 8$ in. Nom. Max. Clad, materials same as (a)

CONCEPT 1 - BOILER COSTS

The following costs for stainless steel boilers were provided by Alaskan Copper Works, Seattle, WA. The carbon steel boiler costs were estimated from the stainless steel costs.

\begin{tabular}{|c|c|c|c|c|c|c|c|}
\hline $\begin{array}{c}\text { Concept } \\
\text { No. } \\
\end{array}$ & $\begin{array}{l}\text { Boiler } \\
\text { Dia, ft }\end{array}$ & $\begin{array}{c}\text { Tube } \\
\text { Dia, in. }\end{array}$ & $\begin{array}{l}\text { No. of } \\
\text { Tubes }\end{array}$ & $\begin{array}{l}\text { Boiler } \\
\text { Height, } \\
\mathrm{ft}\end{array}$ & $\begin{array}{l}\text { No. of } \\
\text { Boilers }\end{array}$ & $\begin{array}{c}\text { Stainless } \\
\text { Steel } \\
\text { Total Costs, } \\
1976 \$ \\
\end{array}$ & $\begin{array}{c}\text { Carbon } \\
\text { Steel } \\
\text { Total Costs, } \\
1976 \$\end{array}$ \\
\hline 1.5 & 8.8 & 12 & 37 & 11 & 40 & $3,400,000$ & 840,000 \\
\hline 1.6 & 9.6 & 14 & 37 & 1.1 & 22 & $2,090,000$ & 484,000 \\
\hline 1.1 & 11.4 & 16 & 37 & 11 & 20 & $2,400,000$ & 702,000 \\
\hline 1.3 & 11.4 & 16 & 37 & 11 & 27 & $3,240,000$ & 520,000 \\
\hline $1.2,1.4$ & 13.9 & 20 & 37 & 11 & 20 & $3,400,000$ & 640,000 \\
\hline
\end{tabular}




\section{CONCEPT 1 - SHIELDING TANKS COSTS}

The following costs were obtained from Reference 35 and updated to 1975:

\begin{tabular}{|c|c|c|c|}
\hline $\begin{array}{c}\text { Concept } \\
\text { No. }\end{array}$ & $\begin{array}{c}\text { Tank Size, } \\
\text { gal } \\
\end{array}$ & $\begin{array}{c}1976 \$ \\
\text { Cost ea., } \\
\text { Stainless } \\
\text { Steel } \\
\end{array}$ & $\begin{array}{c}1976 \$ \\
\text { Cost ea. } \\
\text { Carbon } \\
\text { Steel } \\
\end{array}$ \\
\hline $1.1,1.3$ & 18,100 & 34,000 & 11,000 \\
\hline $1.2,1.4$ & 24,500 & 41,000 & 13,000 \\
\hline 1.5 & 12,500 & 29,000 & 9,000 \\
\hline 1.6 & 14,100 & 31,000 & 9,000 \\
\hline
\end{tabular}




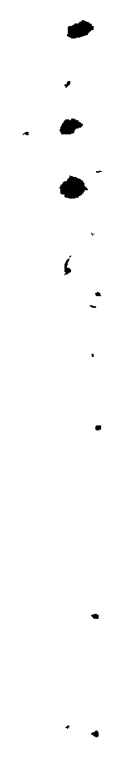


APPENDIX E

REFERENCES 


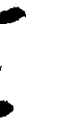

: 
APPENDIX E

\section{REFERENCES}

1. National Research Council Committee on Radioactive Waste Management, Interim Storage of Solidified High-Level Radioactive Waste. National Academy of Sciences, Washington, DC, 1975.

2. U.S. Nuclear Regulatory Commission, Office of Standards Development, Regulatory Guide 3.24 - Guidance on the License Application, Siting, Design, and Plant Protection for an Independent Spent Fuel Storage Installation. National Technical Information Service, Springfield, VA, 22161.

3. G. Safonov, Military Facility Steam from Mixed Fission-Products. RDA-TR-6800-005, R\&D Associates, Santa Monica, CA, March 1975.

4. Retrievable Surface Storage Facility Alternative Concepts Engineering Studies. ARH-2888 Rev., Atlantic Richfield Hanford Co. and Kaiser Engineers, Richland, WA, July 1974.

5. Retrievable Surface Storage Facility Conceptual System Design Description, ARH-LD-140 REV, Atlantic Richfield Hanford Company and Kaiser Engineers, Richland, WA, March 1977.

6. "Exxon Nuclears Tells Plan for Oak Ridge Facility." Nuclear News. 19(4):59, March 1976 .

7. Code of Federal Regulations. Title 10 - Energy, Office of the Federal Register, National Archives and Record Service, General Services Administration, Washington, DC, January 1, 1976.

8. Alternatives for Managing Wastes from Reactors and Post-Fission 0perations in the LWR Fuel Cycle. ERDA-76-43, Report Coordinated for the Energy Research and Development Administration by Battelle, Pacific Northwest Laboratories, Richland, WA, May 1976.

9. C. C. Chapman, H. T. Blair and W. F. Borner, "Waste Vitrification at

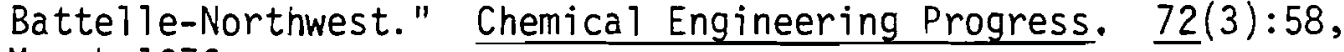
March 1976.

10. "Nuclear News Briefs." Nuclear News. 19(10):127-128, August 1976.

11. B. M. Legler and G. R. Bray, "Concentration and Storage of High Level Wastes." Chemical Engineering Progress. 72(3):52, March 1976. 
12. R. Bonniaud and C. Sombret, "Continuous Vitrification of Radioactive Wastes." Chemical Engineering Progress. 72(3):47, March 1976.

13. J.N. C. van Geel, H. Eschrich and E. J. Detilleux, "Conditioning High Level Radioactive Wastes." Chemical Engineering Progress. $72(3): 49$, March 1976.

14. N. Rueth, "Wrapping Up the Nuclear Fuel Cycle, Part 1 - Reprocessing Nuclear Power's Spent Fuel." Mechanical Engineering. 98(12):32, December 1976.

15. N. Rueth, "Wrapping Up the Nuclear Fuel Cycle, Part 2 - A Permanent Home for Nuclear Waste." Mechanical Engineering. 99(1):20, January 1977.

16. Code of Federal Regulations. Title 40 - Protection of Environment, Office of the Federal Register, National Archives and Record Service, General Services Administration, Washington, DC, July 1, 1974.

17. U.S. Nuclear Regulatory Commission, Office of Standards Development, Regulatory Guide 1.23 - Onsite Meteorological Programs. National Technical Information Service, Springfield, VA 22161, February 17, 1972.

18. U.S. Nuclear Regulatory Commission, Office of Standards Development, Regulatory Guide 4.2 - Preparation of Environmental Reports for Nuclear Power Stations. Revision 2, National Technical Information Service, Springfield, VA 22161 , July 1976.

19. U.S. Nuclear Regulatory Commission, Office of Standards Development, Regulatory Guide 3.26 - Standard Format and Content of Safety Analysis Reports for Fuel Reprocessing Plants. National Technical Information Service, Springfield, VA 22161, February 1975.

20. American National Standards Institute, American National Standard Design Objectives for Highly Radioactive Solid Material Handling and Storage Facilities in a Fuel Reprocessing Plant. ANSI N305, American Institute of Chemical Engineers, New York, NY, 1975.

21. L. S. Tong, Boiling Heat Transfer and Two-Phase Flow. John Wiley and Sons, New York, NY, 1965.

22. W. H. McAdams, Heat Transmission. 3rd Edition, McGraw-Hil1, New York, NY, 1954.

23. M. Jakob, Heat Transfer. 1, John Wi Tey and Sons, New York, NY, 1949.

24. W. Fritz, Verfahrenstechnik. (5):149-155, 1937. 
25. J. R. LaRiviere and E. L. Moore, Conceptual Design Considerations for the Storage of Solidified High-Level Waste in Canisters at a Commercial Fuel Reprocessing Plant. ARH-SA-221, Atlantic Richfield Hanford Co., Richland, WA, November 1975.

26. K. H. Dufrane, "Truck Transport of Spent Nuclear Fuel - A Shift from Rail?", in AIF Topical Conference on Uranium/Fuel Cycle '74. (CONF-740319), New Orleans, LA, March 1974.

27. C. K. Beck, "Intergovernmental Relationships in the Transport of Radioactive Materials," in Proceedings of the Second Annual Legislative Workshop. (CONF-730588), Oak Ridge, TN, May 1973.

28. W. M. Rogers, Jr., "State and Federal Roles in Regulating the Transportation of Radioactive Materials," in Proceedings of the 4th International Symposium on Packaging and Transportation of Radioactive Material. (CONF-740901), Miami Beach, FL, September 1974.

29. Code of Federal Regulations. Title 49 - Transportation, Office of the Federal Register, National Archives and Record Service, General Services Administration, Washington, DC, October 1, 1975.

30. W. A. Brobst, "The State of State Regulations," in Proceedings of the 4th International Symposium on Packaging and Transportation of Radioactive Material. (CONF-740907), Miami Beach, FL, September 1974.

31. Docket No. 36307, Radioactive Materials, Missouri-Kansas-Texas Railroad Company; Docket No. 35312, U.S. Energy Research and Development Administration versus the Akron, Canton and Youngstown Railroad Company et a1.; Docket No. 36336, General Electric Company versus the Akron, Canton and Youngstown Rail Company et al.

32. J. J. Perona and J. 0. Blomeke, A Parametric Study of Shipping Casks for Solid Radioactive Wastes. ORNL-TM-3651, Oak Ridge National Laboratory, Oak Ridge, TN, February 1972.

33. "Agencies Drawing Flak on Proposed Site." Nuclear News, Vol. 19, No. 10, August 1976, pp. 111.

34. "Transport Economic." Interstate Commerce Commission, Bureau of Economics, III (1), 1976.

35. M. S. Peters and K. D. Timmerhaus, Plant Design and Economic for Chemical Engineers, McGraw-Hi11, New York, NY, 1968.

36. J. 0. Blomeke, C. W. Kee, and J. P. Nichols, Projections of Radioactive Wastes to be Generated by the U.S. Nuclear Power Industry. ORNL-TM3965, Oak Ridge National Laboratory, Oak Ridge, TN, February 1974. 
37. "Siting of Fuel Reprocessing Plants and Related Waste Management Facilities," Federal Register, 35(222):17530, November 14, 1970.

38. J. J. Perona and J. 0. B1omeke, A Parametric Study of Shipping Casks for Solid Radioactive Wastes. ORNL-TM-3651, Oak Ridge National Laboratory, Oak Ridge, TN, February 1972.

39. J. J. Perona, R. S. Dillon and J. O. Blomeke, Design and Safety Considerations of Shipping Solidified High-Level Radioactive Wastes. ORNL-TM-2971, Oak Ridge National Laboratory, Oak Ridge, TN, December 1970.

40. W. D. Turner and M. Siman-Tov, HEATING3--An IBM 360 Heat Conduction Program. ORNL-TM-3208, Oak Ridge National Laboratory, Oak Ridge, TN, February 1971.

41. D. H. Lester, $\mathrm{SrF}_{2}$ Capsule Design for Heat Engine Applications. BNWL-2042, Battelle, Pacific Northwest Laboratories, Richland, WA, Apri1 1976.

42. D. Q. Kern, Process Heat Transfer. McGraw-Hi11, New York, NY, 1950.

43. R. H. Perry and C. H. Chilton, Chemical Engineers' Handbook. McGraw-Hi11, New York, NY, 1973. 


\section{DISTRIBUTION}

NO. OF

COPIES

OFFSITE

1

ERDA Chicago Patent Attorney 9800 S. Cass Avenue

Argonne, IL 60439

A. A. Churm

ERDA Division of Biomedical and Environmental Research Washington, DC 20545

J. N. Maddox

2

ERDA Division of Waste Management, Production and Reprocessing Washington, DC 20545

G. W. Cunningham

C. W. Kuhlman

9

ERDA Nuclear Research and Applications Division Washington, DC 20545

T. J. Dobry, Jr.

N. Goldenberg

A. P. Litman

3. 3. Lombardo

W. C. Remini (3)

B. J. Rock

E. J. Wahlquist

1 ERDA Oak Ridge Operations Office P. O. BOX E Oak Ridge, TN 37830

D. C. Davis, Jr.

2

ERDA Savannah River Operations Office P. 0. Box A

Aiken, SC 29801

R. H. Bass

T. B. Hindman

27

ERDA Technical Information Center 
$2 \quad$ Batte1le Columbus Laboratories

505 King Avenue

Columbua, $\mathrm{OH} 43201$

W. J. Zielenbach

W. M. Pardue

20

Department of the Army

Headquarters, U.S. Army

Facilities Engineering Support Agency

Fort Belvoir, VA 22060

H. D. Hollis

H. Musselman

G. S. Stewart (17)

1 Electronics and Applied Physics Division

Building 347.3, AERE Harwell

oxfordshire 0X11 ORA

Great Britain

E. H. Cooke-Yarborough

1 Exxon Nuclear Company Inc.

Research and Technology

2955 George Washington Way

Richland, WA 99352

L. T. Lakey

$1 \quad$ General Atomic Company

P. 0. Box 81601

San Diego, CA 92138

H. C. Carney

1 General Electric Company MSVD

P. 0. Box 8555

Philadelphia, PA 19101

P. E. Brown

1 General Electric Company, Vallecitos Laboratory

P. 0. Box 846

Pleasanton, CA 94566

G. E. Robinson 
Kaiser Engineers

Kaiser Center

300 Lakeside Dr.

Gakland, CA 94666

J. S. Ritchie

1

Lawrence Livermore Laboratory

P. 0. Box $808(L-502)$

Livermore, CA 94550

R. J. Cena

Los Alamos Scientific Laboratory

P. 0. Box 1663

Los Alamos, NM 87544

S. E. Bronisz

R. A. Kent

R. N. Mulford

2

Monsanto Research Corporation

Mound Laboratory (ERDA)

Nuclear Operations

P. 0 . $50 \times 32$

Miamisburg, $\mathrm{OH} 45342$

W. T. Cave

R. Dewitt

$1 \quad$ Naval Nuclear Power Unit

Code 70

Port Hueneme, CA 93043

F. E. Rosel1

$1 \quad$ Naval Facilities Engineering Command

Nuclear Power Division (FACO4N)

200 Stoval1 Street

Alexandria, VA 22332

A. A. Arcuni

Navy Office of the Chief of Naval Operations

Head, Reactor Branch

2

Oak Ridge National Laboratory

Oak Ridge, TN 37830

E. Lamb

A. C. Schaffauser 
NO. OF

COPIES

1

$R$ \& D Associates

P. 0. Box 3580

Santa Monica, CA 90403

G. Safonov

2 Science Applications, Inc.

1385 George Washington Way

Richland, WA 99352

J. R. La Riviere

3 Teledyne Energy Systems

$110 \mathrm{~W}$. Timonium Road

Timonium, MD 21093

P. Dick

R. Hannah

P. Vogelberger

Westinghouse Astronuclear Laboratory

P. 0. Box 10864

Pittsburgh, PA 15236

C. C. Silverstein

ONSITE

2

ERDA Richland Operations

W. A. Burns

W. C. Johnson

3

Rockwell Hanford Operations

E. L. Moore

R. C. Roal

D. D. Wodrich

40

Battelle-Northwest

W. E. Anderson

D. G. Atteridge

J. W. Bartlett

W. J. Bjorklund

W. F. Bonner

L. M. Browne

C. C. Chapman

M. 0 . Cloninger 
Battel le-Northwest (contd)
J. G. Desteese
G. W. Dawson
H. T. Fullam
R. J. Hall
J. H. Jarrett
R. C. Li ikala
J. L. McElroy
R. W. McKee
R. E. Nightingale
D. E. Olesen
A. M. Platt
W. E. Sande (10)
S. C. Slate
D. S. Trent
H. H. Van Tuyl
L. D. Williams
S. W. Wilson Technical Information Files (5) Technical Publications 


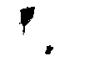

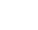

. 